\title{
Biological Specifics of Musical Performing Memory Essence for Musical Performance Efficiency
}

\author{
Maria Dymnikowa ${ }^{1,2,4 *}$, Elena A. Ogorodnikova ${ }^{1, \#}$, Valentin I. Petrushin ${ }^{3,4+}$ \\ ${ }^{1} \mathrm{PhD}$ in biology, I. P. Pavlov Institute of Physiology, Russian Academy of Sciences \\ Makarova nab. 6, 199034 Saint-Petersburg \\ ${ }^{2} \mathrm{PhD}$ in psychology, Laboratory of Music-therapy, Institute of Psychiatry and Neurology \\ al. Sobieskiego 1/9, 02957 Warsaw \\ ${ }^{3}$ Prof. in music psychology, P. I. Tchaikovsky Moscow State Conservatory \\ Bolshaya Nikitskaya st. 13/6, 125009 Moscow \\ ${ }^{4}$ Association of Musical Psychologists and Psychotherapists \\ Akademika Anohina st. 38/3, 119602, Moscow \\ *Email: dmwl [AT] bk.ru \\ ${ }^{\#}$ Email: elena-ogo [AT] mail.ru \\ ${ }^{+}$Email: valpetr-psy [AT] yandex.ru
}

\begin{abstract}
In classical music art discipline, the memory for musical performance (i.e., music performing memory MPM) at typological analysis level is the type of musical executive prospective memory based on executive functions and biological conditions. Its structural components are semantic declarative, kinesthetic, and emotional memory. Musical performance concerns the production of musical artwork by vocal or musical instrument forms. The efficiency of this process is conditioned by ergonomic, effective work on learning and memorizing the music. It is regulated and organized from the level of 'reading a vista' the musical notes text until completed memorizing for the target level of music performance. The article, from the health psychology mainstream, presents methodical, practical tips with recommendations resulting from the biological principles, regularities, and specifics of this process revealed in the empirical data of such areas as neuropsychology, psychophysiology, cognitive psychology, biological psychology, and music pedagogy, with additional independent empirical verification in counseling of musicians at the professional music education level.
\end{abstract}

Keywords - musical performing memory, musical performance efficiency, memorizing the classical music work.

\section{INTRODUCTION}

The efficiency is defined in three directions, such as: 1. good and optimal use of time and energy, ability to accomplish, production of the desired effects or results - in a way that does not waste any time and effort; 2. state or quality of being efficient; 3. competence or effectiveness in performance processing. The musical performance is the process during which music's content is realized by feeling the music, forwarded, and presented to music's listeners and recipients. In classical musical art, it contains mostly the reproduction processing, as the interpretation of earlier prepared and edited musical compositions, which do have different possibilities of its' content decipher. Factors describing the music's matter - such as tempo - speed, phrasing with breathing, dynamics, articulations, pitch and rhythm units are belonged to performer's feeling, experiencing, expressing and cognitive understanding of music content, on the background of adopted and imposed stylistic interpretation as the pattern of possible template presentation of music. In contrast, the improvisation and more freedom of the interpreted and presented contents usually belonged to performing the popular, jazz, and rock music without strict decoding as it concerns the classical musical art. The reproduction processing concerns the conscious presentation of what has been learned and memorized earlier. Thus it is the planned and programmed musical behavior act with its' possible small differences in each performing the music's content, especially on the case of emotional music's matter. 
Learning and memory are biological, inborn psychological capabilities of our mind [205]. Learning is the process of acquiring new knowledge about the world, whereas memory is the process of retaining and reconstructing that knowledge overtime during our fate - range. And most of our knowledge and most of our skills are not innate inborn but learned, where special cue belongs to the proprioception processing. Here proprioception, as bodily neuromuscular sense of positioning and movement, is a part of sixth receptor defined as 'somato-sensation' i.e., somatosensory perception. It includes additional four sub-categories of feeling reception as a balance (i.e., equilibrioception), a pain (i.e., nociception), a temperature (i.e., thermos-reception), and a pressure - vibration discriminatory touch (i.e., mechano-reception) [4]. This sensory feedback arises in the peripheral nervous system (PNS), and forward its information to the central nervous system (CNS) in two directions, at the level of the spinal cord (reflexive) and cerebral cortex for deeper and higher stimuli processing [174].

According to Sacks [358], proprioception is a continuous, unconscious and automatic sensory flow from the moving parts of our body (muscles, tendons, joints), through which their position, tone, and movement are constantly determined, controlled and corrected, also with taking into account the influence of the emotional state on their activation. Therefore humans are in large part of what they have learned, formed up, perceived, coded, and what they do remembering, keeping, and forgetting. The memory enables information to be stored and retrieved in the time range from seconds to years and is essential for daily life. The biology definition of memory concern with enduring changes in the mechanisms of behavior based on prior experience with environmental input, where humans have evolved specific plasticity systems with methods to retain information that may be useful at a later time. Here memory is the evidence when some observed output at time point B can be attributed to an earlier input experience at time point A [92]. It involves retaining specific information over a delay, based on encoding, keeping (i.e., storage), and recalling psychological processes, available through the memory consolidation process. At the same time, learning is the process of acquiring new information.

The mechanisms of cellular and synaptic levels for memory consolidation look to be universal among animals. However, there is evidence that specific aspects of human memory can be modeled in non-human animals, including such processes as declarative memory, and prospective memory (i.e.,'remembering to remember') [91]. Thus musical performing memory belongs to higher-order memory type as a very complex and quite complicated ability. The underlying molecular and cellular mechanisms of learning and memory have been conserved during evolution [399], with Stock and Zhang [405] provided evidence that learning and memory are molecularly separate processes, what might be defined as learning is the obtaining of adaptive abilities and skills. In contrast, memory is the processing of information transforming and keeping in mind until it's relevant and useful for life existence. From the position of associative learning, the learning mechanism is inseparable from the storage and reproduction mechanisms.

Learning mechanisms extract potentially useful information from experience, and memory mechanisms carry the necessary information in time in a form accessible for reproduction throughout the entire storage time [140]. At the psychological level - learning is the process of forming associations, and memory is the translation of these associations into changes in human behavior, where reinforcing a specific behavior improves attention to this behavior significantly $[375 ; 383]$. At the neural level - learning is the restructuring of the plastic structures of the nervous system based on experience, and memory is the essential part of this ever-changing structure, with the representation of the activity of some neural networks in the brain [308]. What is learned and memorized is always a repetition of the conditions that occurred in the learning process [308]. When re-learning or re-training, the primary memorial trail only partially enters the newly created one, and the engram itself is quite plastic and changes both with time and under the influence of various influences [115]. Here the primacy effect of memory influences the second and every following selected form of producing the musical performing content with small corrected changes.

The present article concerns the range of professional classical music activity, directed especially for performers - transmitters of classical music literature. That activity is defined as music performance processing and concerns 'music performers' specialists of selected styles, compositions, composers, and historical periods of musical art products (i.e., creations). At the same time, it is the memory background for classical music literature interpretation during concerts, recordings, or teaching processing. In scientific literature of cognitive psychology, neuropsychology and music psychology, there is an absence of mentioning the music memory in classifications of cognitive functions or musical functions, where terms 'function' and 'process' become semantic synonyms. The music memory - as an ability - does exist only in classifications of musical skills. Thus this memory might be described by other types of memory presented in cognitive psychology and neuropsychology schemes of cognitive functions. Here the music performance, as processing, also concerns 'programmed behavior' actions, thus it is primarily an executive function in cognitive psychology and music psychology ranges. 
The present article includes typological and methodological study for transferring the scientific knowledge from psychology, psychophysiology, and neuropsychology areas to the area of musical performance efficiency in classical music professional range with methodological principles settings. The present article describes the type of memory for musical performance (i.e., musical performing memory - MPM), as complex special professional ability, including its executive function processing, during a typological analysis of memory types and multiple special types of intelligence extracted by H. Gardner. Additionally, there are presented biological specifications for components of that complex musical function, which are conditioning its' proper functioning, and essentially affecting the ergonomic learning and memorizing of classical music's compositions. The methodological principles and practical conclusions cited and described in the article were presented in musicological literature as external observations and facts of the 'art of musical performance', also empirically verified in psychological and music support for children accessing the professional music education up to the formal maturity level.

The effective use and regulation of this function do affect the quality and the musical fate of human's professional classical musical activity in such ranges as music competitions, festival auditions, music recordings, music concerts as part of professional education, job position, professional music performance practice in solo or chamber forms, additionally in the frame of own concert practice, music performance presentations as part of teaching position and master classes statement. From the medical perspective of ergonomic classical musical performance this thematic area concern healthy professional activity for enabling long-term as an optimally long period of professional activity, with deliberate inhibition of the risk of developmental, age-related, striking and functional changes due to overloading with this occupation, from cognitive, emotional and kinesthetic behaviors. It's especially important to minimize the risk of overload statement of these behavior activities with consequences of illnesses on orthopedic, neurologic movement, cardiovascular and respiratory systems, cognitive mental condition, emotional boredom and burnout, or artistic musicality burnout. For professional musical vocal or music instrument training perspective, it gives the chance to reduce or liquidate such negative symptoms as mental fatigue, manual or kinesthetic 'over-playing' with losing the control for preparing the required performance, boredom statement, with minimization of the stage-fright process as the consequences of its disturbances for the musical performance efficiency.

The paper describes biological principles and specifics of efficiency of memory for music performance processing, that have been revealed in experimental scientific studies and got additional independent empirical verification in practical observation during the counseling process of musicians at a professional music education level. Whereas all possible negative symptoms and effects in musical performance caused by the: 1 . attitude to the tendency to harmful addictions; 2. eating, breathing, or movement disorders; 3. any birth and development defects with the effects of restrictions on working capacity: 4. sleep, mood, and cognitive disorders; 5 . a state of pain (of a chronic or functional nature) felt during the musical performance exercise; 6. reduced motivation and the need (at the biological level) of communing with classical music art in the form of professional and living activity do require separate medical or psychotherapeutic specialization intervention, with preventive or corrective assistance. Importance and the necessity to develop the technology of efficient memorization of classical musical works in the field of classical music art was reported independently in the reviewers' methodological suggestions on the musical memory works included Ph.D. thesis in musical memory diagnosis [117].

\section{MUSICAL PERFORMING MEMORY SPECIFICATION}

The theory of multiple intelligences, defined by H. Gardner, differentiates them into specific modalities, very near to special separate functions or abilities of specific practical areas [141, 142, 143, 146]. All of them include basic biological background defined in previous general intelligence, which is divided into three main directions - cognitive, emotional, and social abilities, with a fresh tendency to look for the practical range. Gardner noted eight typed of 'multiple intelligences' firstly. Here six of them (musical, visual-spatial, verbal-linguistic, logical-mathematical, bodily-kinesthetic, intrapersonal) do concern the classical music performance processing from the musical performing memory perspective. The others concern interpersonal (crucial for professional music performance learning) and naturalistic durations. Latterly he added a spiritual intelligence [146] to indicate the parallels between primarily general cognitive and emotional intelligence types [142, 144], which is crucial to the quality of music performance especially for musicality manifestation but noted the difficulties with codifying quantifiable scientific criteria for this type [145]. This type was empirically observed in educational research area [425], with using that term in D. Zohar [476], K. O’Donnell or M. Levin [251] studies on human's emotional and spiritual development. 
Gardner proposed finally in 2009 to include an existential intelligence into his model of multiple intelligences [142]. It is near to the direction of the modern tendency of 'practical intelligence', and in 2016 mentioned target reason to add and extract the 'teaching-pedagogical intelligence' that allows the successful teaching and educating others, what is also crucial for the professional music performance learning. During the analysis of Gardner's model in the duration of special narrow abilities or functions that have a background in the general intelligence structural components, there now exists the form of artificial intelligence. As an example, N. B. Adams noted the digital (meta) intelligence that is composed of other identified and revealed intelligence that stemmed from human relations, communications (interaction), and reactions with digital computers and IT technology products [3]. This is an indisputable objective confirmation of different use of 'intelligence' term in Gardner's orientation and general intelligence direction. Here narrow special abilities needed for effective human existence are defined as 'intelligence types' by Gardner, which do have practical adaptation for specific professional skills, such as classical musical performance processing with its memory type. Typological analysis of psychological processes occurring in the music performing memory processing with including the intelligence types extracted by H. Gardner, allowed to elaborate a structural scheme (№1) of the components of musical performing memory for the classical music performance production area.

\section{Scheme 1. Structural components of musical performing memory}

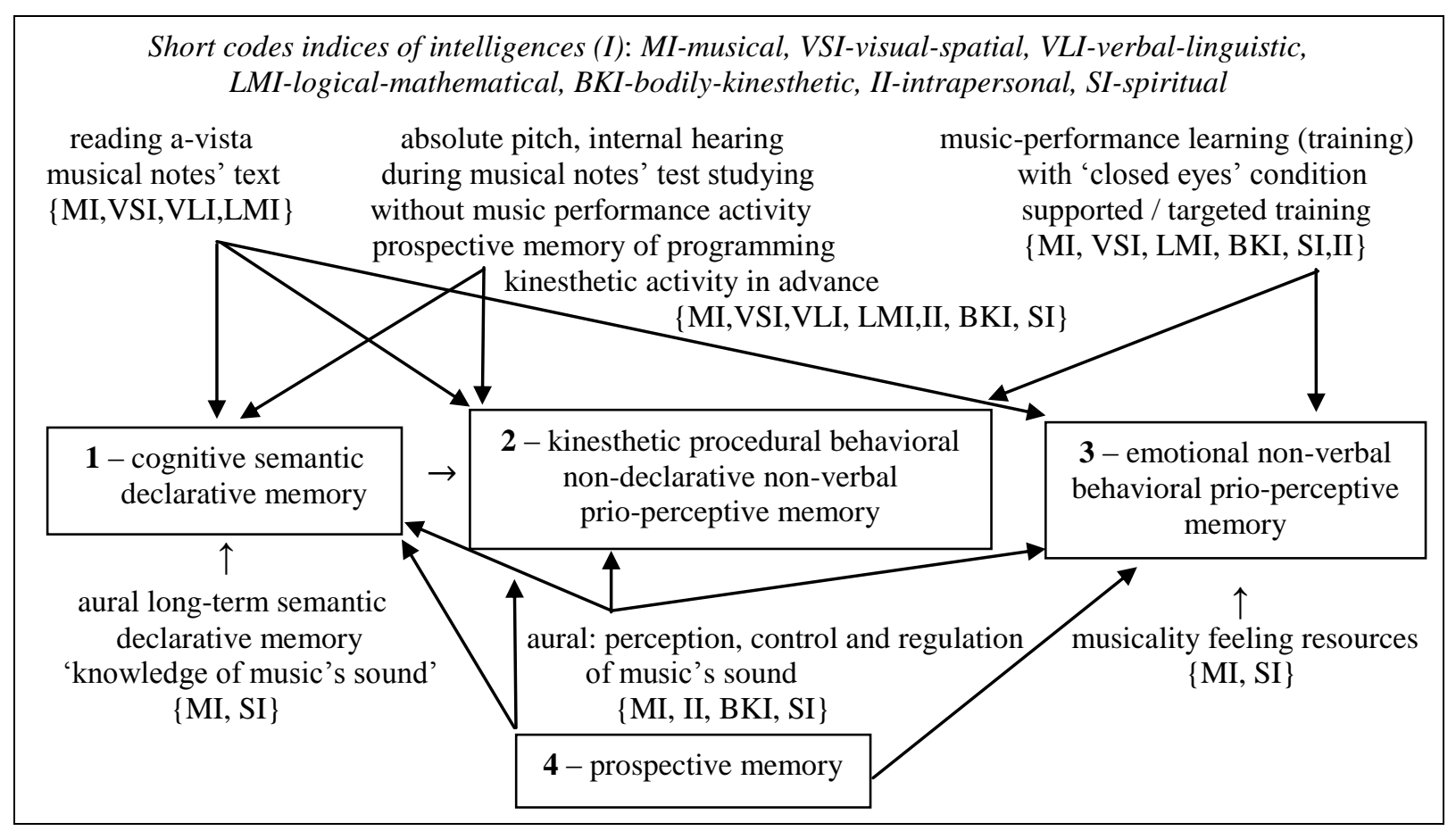

The main three components of musical performing memory are described by cognitive, kinesthetic, and emotional contexts, which are regulated in the content of prospective memory. They include primary aural, visual, kinesthetic, and emotional (spiritual) musical abilities where interpersonal intelligence and teaching-pedagogical intelligence and stage-fright condition are external backgrounds that do optimize musical performing memory efficiency during professional music studying process. Elements of musical composition [339] do order the sound material in their cooperation with acquiring the specific shape of such structural components as: I. rhythmic and pitch-harmonic organization of musical notes as semantic content of musical composition that is not changed during performance processing; II. articulation and coloristic content matter of sound extraction processing, which correlates with dynamic content characteristics determine the essence of musical performance training during producing the final expected and allowed form of professional musical performance. These structural components influence different elastic variants of musical performance, especially including the changed external acoustical environment conditioned for musical sound. It forces the supportive preparation forms that mediate in the creation of a purposeful final maturity form of musical performance. It required elastic adaptation with learned material to different external acoustical conditions, especially experienced in the live musical concert; III. agogics (i.e., tempo speed) that determine the time speed of musical performance and is conditioned additionally independently by internal feeling the time of musical performer. 
The structural components of music presented in part 'I' do not change during whole learning cycle of memorizing the musical performance at the maturity intentional level, whereas structural components of music presented in parts 'II' and 'III' do change during whole learning cycle of memorizing the musical performance with forming up the indirect supportive forms needed to obtain the required maturity form of musical performance. They do determine the time-part and supportive forms of musical performance during the initial learning state period. It concerns the production of part-time and working musical performance variants. They are presented at the first hours of musical performance learning at the level of fresh primary reading a-vista of musical notes content on the vocal or musical instrumental form, with its further transformation into a final targeted form of musical performance. These selected variants of learning at the beginning level influence to the quality in the creation of a purposeful final maturity form of musical performance, and allow to prepare the final presentation of music already at the beginning of learning and memorizing the content of musical work. For advanced virtuosic musical works, it concerns selected material for obtaining on and training out the required kinesthetic, emotional, and cognitive lightness with efficiency, based on methodological literature for a selected musical instrument or vocal teaching.

Musical performance processing contains planned action with repeated repertoire production memorized earlier in a different time, places, and conditions of classical music artwork presentation. It includes programmed behavior and the content that is required to be remembering. Thus it is based on executive functions and prospective memory. This methodological analysis is revealing the memory for musical performance (i.e., music performing memory MPM) as a type of musical executive prospective memory, which constituent components are described. Prospective memory consists of forming a representation of a future action with use of information to perform the planned activity [110, 226], temporarily storing representation in memory, and retrieving it at a future time point, requires active maintenance of a planned action [395, 396]. It concern active monitoring and automatic processing with divided attention state [278], where attentional resources that are diminished with age [273]. It constitutes a specialized type of information processing and refers to functional or strategic-organizing aspects of memory [201]. It was revealed firstly in 1975 by Meacham and Dumitru [285], with later its notation such as remembering to remember [91, 110], delayed intentions [159], remembering a plan of action, memory for/of the future [160], and memory for intentions [342].

Prospective memory definition includes the following descriptions: 1. remembering to carry out the intended action at a certain point in the future [123]; 2. storing and sharing the action plan in its durable form [201] i.e., a conscious shift of attitude towards the future and activities that are to take place only at a specific moment of time or actions that follow a specific event or situation [285]; 3. a set of processes or capabilities enabling the formulation of goals and intentions, their storage and implementation when appropriate conditions occur (a specific hour or situation) [123, 160, 227]. This memory type includes the following stages [226]: 1. intention formation - required planning skills controlled by executive functions; 2 . intention retention in long term memory; 3 . intention initiation dependent from event or time context - controlled by executive functions; 4. intention execution with the implementation of the intention in accordance with the previously assumed plan - controlled by executive functions. Here intention initiation with intention execution does require self-regulation skills (because the action must start at the right moment, not sooner and later) and cognitive flexibility (e.g., the ability to adjust the plan up to date). Division of prospective memory based on recall-inducing guidelines [121, 242] applies to: 1. event-based prospective memory - it is responsible for remembering to perform a given task at the moment when a specific event occurs; 2. activity-based prospective memory - it is similar to event-based prospective memory, here the implementation of the intention is activated by an external signal, as the specific activity of the individual itself (its termination or start), here musical performance processing belongs; 3. time-based prospective memory - it refers to remembering to complete a task at a specific time in the future. Prospective memory involves intension's remembering and fulfilling, requires episodic, declarative and retrospective long-term memory followed by supervisory executive functions [201, 271]. Long-term memory allow to remember what action should be done or taken in future further period, whereas executive functions reminds us when we should start its implementation, where working memory controls the processing of information on an ongoing basis when the intended action is carried out [201, 226]. Executive functions [266, 103] concern the necessary cognitive processes for cognitive control and monitoring of behavior. They include cognitive functions such as attention, attentional and inhibitory control, cognitive selection, inhibition and flexibility, working memory, thinking with reasoning and problem solving, planning and fluid intelligence. They are conditioned target, planned, controlled, regulated, monitored, corrected, behaviors, which relate to musical performance behaviors in classical musical art range. Additionally prospective memory is a specialized type of information processing and refers to the functional or strategic-organizing aspects of memory [459]. It combines executive functions with declarative memory by remembering previous information and using it to perform the intended action in the future. It also requires the involvement of operational memory that monitors the information processing process during the implementation of the planned activity [201], because the processes occurring in the prospective memory are phased and include: creation, storage, start of implementation (initiation) and execution of intention [227]. 
Here also the role of attention and thinking processes with the relationship between this memory, motivational processes, and the functioning of the 'working our-self' is important for prospective regulation efficiency [276]. Since the coding in prospective memory is only intentional [70], where information can be recalled many times, but the task will be fulfilled only under the condition if the information is retrieved from memory at the moment when the planned activity should be performed [408]. The efficient functioning of prospective memory requires the cooperation of its two components - prospective and retrospective [119, 307]. Here prospective (i.e., executive) component controlled by executive functions to initiate and implement an intention in response to an appropriate external or internal stimulus and allow to start operating in response to a hint or at the right time. Whereas the retrospective component is controlled by long-term memory, it is responsible for storing information about the content of the planned activity, and thanks to it, a person remembers what action is taken for realization. Here the ability to planning and regulating own intentions is a fundamental value in the aspect of prospective memory development, especially including the autonomy of own behaviors, i.e., the process beginning in early childhood [123]. According to research data, significant progress in the development of this memory's type is observed between 7 and 12 years, further growth persists into early or late adulthood [452, 475]. Here, the effect called prospective memory paradox relates to the increase in prospective memory observed only during testing measures performed in natural conditions [329].

In neuropsychological data, prospective memory is associated with the activity of the down left parietal lobe, left anterior gyrus, left and right hippocampal gyrus [232, 332], 7 and 40 Brodmann area in coding and storage of information necessary to perform prospective activity [58]. Also, the anterior prefrontal cortex supports executive functions' control for supporting effortful prospective memory monitoring processes in fMRI (functional magnetic resonance imaging) and PET data (with positron emission tomography) [59, 61, 343], and the medial temporal lobe, which includes the hippocampus, supports reflexive-associative retrieval [298] in spontaneous retrieval of prospective memory. Additionally, frontal lobes are responsible for executive functions, for controlling the retrospective component of prospective memory, as well as long-term memory [57, 71, 229], with evidence in clinical PET study about the relation with executive processing [226, 447]. Brodmann field 10 (frontal cortex) plays a crucial role in prospective memory functioning [57, 58, 357]. It myelinates quite slowly. It revealed in studies about the relationship between late myelinated areas and complex cognitive functions [447]. Its activity occurs in reminding about the intended action and recognizing the clue that triggers the intended. Here, recalling the intention to perform a particular prospective task is mainly associated with the activity of the lateral cortex $[59,60]$. Whereas identifying the stimulus being the signal to perform the prospective task involves also the central part of the cortex and the anterior part of the rim bend, while maintaining the intention involves the posterior cortical area [389]. The frontal fragment of the frontal cortex is responsible for carrying out the complex tasks of prospective memory, and the lateral part allows extracting the appropriate action plan. And the ability to the deferred recollection of previous intentions depends mainly on the interactions of the prefrontal and medial temporal areas associated with hippocampal activity [452] Also, the frontal cortex controls the process of switching attention in response to both external and internal stimuli (ideas, thoughts). When attention is involved in the process of waiting for a given external stimulus the lateral areas of the frontal pole are activated. Whereas in the case of tasks requiring the activation of the internal pointer - the medial areas of the frontal lobe pole are activated [57].

Time-based prospective memory determines the activity of the right upper frontal gyrus, anterior medial part of the frontal lobe, and anterior rim gyrus. Here, damage to the right side of 10 Brodmann's area is associated with time-based prospective memory deficits without event-based prospective memory deficits [435]. Prospective memory disorders may result from: 1. a retrospective component (the inability to associate the intention, and even difficulty remembering the intent in the first phase of the prospective memory); 2. prospective component (resignation from the intention, joining in the wrong moment, inefficient use of auxiliary strategies). Here deficits can be limited to time or event context. Prospective memory deficits revealed in complex clinical conditions, such as important for: 1. children and youth - attention deficit hyperactivity disorder [13], various forms of substance abuse and exposure [179, 180, 181, 182, 272, 422, 451], and obsessive-compulsive disorder [93]; 2. adults and elderly - mild cognitive impairment [36] and Alzheimer's disease [424]. Prospective memory is important to maintaining health and safety [108, 109] since around $80 \%$ of everyday memories are related to prospective memory [228]. Its intentions exist at a heightened level of activation and allow it to be recognized quickly in response to relevant environmental cues [159]. This memory type might be improved during on avoiding interruptions [120] or boost prospective remembering at the encoding stage, with the influence of implementation intention encoding on later performance [279]. The solution referred to as implementation intention encoding [158], involves specifying a cue for when the intention should be executed. People typically encode intentions in a very general manner, and these general intentions are often to go unfulfilled [158]. Thus musical executive prospective memory must be programmed with very detailed descriptions for each note, bar, or musical phrase of musical work's performing with readiness to adapt to flexible changes of performance conditioned by external acoustic factors and aesthetic requirements of musical interpretation. 


\section{BIOLOGICAL SPECIFICS OF SLEEP-DEPENDENT MEMORY PROPERTIES FOR MPM}

Sleep-dependent memory processing primarily concerns the role of sleep in memory encoding and memory consolidation. Memory consolidation refers to a process whereby a memory becomes increasingly resistant to interference from competing or disrupting factors in the absence of further practice when the memory becomes more stable [259; 300]. Preston and Eichenbaum [335] biological studies reveal that the consolidation of some memories in the mammalian brain involves, also, a time-dependent transfer of information from one brain region, the hippocampus, to another, the medial prefrontal cortex. Memories can reside permanently in both those regions, so interact under some circumstances. The post-learning interaction between the hippocampus and medial prefrontal cortex is the formation of memory 'schemas', which give an animal the ability to resolve conflicts between new events and old memories [335]. The consolidation of memory in the mammalian brain occurs at the cellular (synaptic) level [137]. It includes activation of various protein kinases or protein phosphatases, which in turn can trigger protein synthesis and gene transcription or repression. The molecular products of this protein synthesis and gene transcription (repression) mediate the strengthening and growth, or the weakening and retraction, of synapses; the final result is the persistent modification of neural circuits in an animal's nervous system that constitutes memory. Abel et al. [1] biological studies reveal that sleep is critical for the consolidation of many forms of memory in mammals. Electrophysiological recordings from single 'place cell' neurons in the hippocampus of rats during a spatial learning experience and non-REM sleep immediately after such learning have shown that the neurons exhibit similar patterns of firing during learning and sleep. This finding has led to the idea that learning-induced patterns of hippocampal activity are 'replayed' during the beginning period of the sleep and that this hippocampal reactivation plays a role in memory consolidation. When memories undergo successful reconsolidation, they become strengthened. Conversely, if reconsolidation is disrupted, the memory is weakened or entirely eliminated [92].

The consolidation process can also be expanded to include more than one phase of post-encoding memory processing, which can be defined as stabilize memories and enhance them. The stabilization phase of consolidation appears to occur largely across time, independent of the brain state [139, 297]. In contrast, the enhancement stage appears to occur primarily during sleep, either restoring previously lost memories or producing additional learning [443]. Effects of sleep on encoding and consolidation do concern additional post-encoding stages of memory. It includes the integration of recently acquired information with past experiences and knowledge (as a process of memory association) with the anatomical reorganization of memory representations (as a process of memory translocation) [122, 403], where emotion also facilitates memory encoding [191, 336, 439, 440, 441]. REM sleep - stage plays an active role in memory consolidation [97]. In studies with modification of post-training sleep, it has been shown by using positron emission tomography (PET) that patterns of brain activity expressed during training on a motor sequence task reappear during subsequent later stage of the REM sleep - stage [269, 445]. Here the extent of learning during daytime practice exhibited a positive relationship to the amount of reactivation during the REM sleep - stage [318]. Also the NREM sleep - stage is a crucial determinant of successful motor memory enhancement [444]. Since daytime motor skill practice on a similar task is accompanied by a discrete increase in the subsequent amount of NREM slow-wave EEG activity over the parietal cortex at the start of the night. This increase in slow-wave activity is proportional to the amount of delayed learning that develops overnight. When humans show the greatest increase in slow-wave activity in the parietal cortex at night, then it is produced the largest motor skill enhancement the next day [192]. Additionally, daytime task learning was associated with hippocampal activity, specifically during post-training slow-wave sleep. Here the amount of slow-wave sleep reactivation in the hippocampus was proportional to the amount of next-day task improvement, which suggests that this reactivation is functional and leads to delayed memory improvement. Such sleep-dependent replay may potentially modify synaptic connections established within specific brain networks during practice [446]. Thus sleep-dependent motor learning is associated with a large-scale plastic reorganization of memory throughout several brain regions, allowing skilled motor movements to be executed more quickly, more accurately, and more automatically the following sleep.

Sleep-dependent motor memory consolidation depends upon the recruitment of relevant neural substrates, hippocampus in particular, and specific architecture of the intervening sleep period, such as sleep spindle and slow-wave activity $[218,133]$. Slow-wave sleep may be particularly important also for consolidation of retrospective and prospective memories [107, 378, 453]. Post-learning sleep facilitated a reorganization of task-dependent activity. Research with polysomnographic recordings during post-learning sleep demonstrated that both slow-wave activity and sleep spindles were altered in frontal and parietal cortices [113] following the initial learning session [192, 244, 417, 418]. Here the increase in slow-wave activity in the parietal cortex was significantly correlated with overnight performance improvements [192, 244]. Thus different sleep stages do have a crucial role in motor sequence's memory consolidation processes [149]. 
Also hippocampal activity in both complex implicit and explicit motor sequence learning is well documented, where sleep specifically favors the consolidation $[5,6,7,8,9,10,81,98,100,129,134,154,252,286,292,296,347$, 352, 368], the development of which necessitates more cerebral control resources in prefrontal regions [64]. Initial implicit and explicit motor sequence task-related increase of hippocampal activity has been shown to emerge after sleep periods $[9,11,135,252,401,446]$ in proportion to the time spent in slow-wave sleep [81]. The hippocampus plays a crucial role in the retrieval of learned sequences [354], where sleep participates in the reorganization of the functional connectivity of the hippocampus [9]. Hippocampal activity during initial training might tag the memory traces that are consolidated during subsequent sleep periods [218]. It may influence implicit sequence learning based on the formation of contextual associations [69, 400]. It is conditioning that sleep favors the consolidation of ordinal properties of a motor sequence [267, 398] or of relevant information made pertinent by reward [132] or expectancy [455]. The hippocampus with prefrontal and parietal cortices participate in forming up the spatial map of motor sequences during early learning. This map is interpreted to be consolidated during subsequent sleep in hippocampal-frontal networks that would be activated again during the retest period so that this consolidated spatial map of movements can be transformed optimally into fast and accurate movements [7]. Sleep facilitates the consolidation of more complex motor behaviors, especially in the sequence learning context, including explicit, abstract, and complex information. All these features have been shown to depend on the hippocampus. Sleep enhances consolidation of these specifically learned sequential movements, with protecting them temporarily against the negative interference effect mediated by competing for motor memories [218]. The role of the primary motor cortex in long-term motor memory retention belongs to the supporting the motoric representation of learning [5, 207], where this motor sequence's memory consolidation processes do not depend on sleep [5, 6, 77, 78, 175, 462]. The role of the striatum in motor sequence memory consolidation has been shown to increase monotonically during the day, with reaching significant and maximal activity $24 \mathrm{H}$ after implicit sequence learning [9, 113], where this memory consolidation process does not depend on sleep [5, 428].

Hippocampal replays during sleep determine striatal reactivations and facilitate the consolidation of motor sequence memories in both hippocampo-cortical and striatal-cortical networks, where the relation between hippocampo-cortical and striatal-cortical networks overnight may also forming up the interaction between the two networks [7]. An abstract representation of motor sequence learning, supported by hippocampo-cortical networks, requires sleep for optimal consolidation. In contrast, the motoric representation of motor sequence learning, supported by sensorimotor networks, including the primary motor cortex and striatum, seems to undergo time-dependent consolidation processes [5]. The prefrontal cortex codes an abstract representation of the temporal order of the motor sequence rehearsed during learning [19], which is crucial in the interaction between the striatal and hippocampal systems during motor sequence learning [10] that is known to condition subsequent sleep-related consolidation [11]. The decrease in prefrontal activity is usually observed when performance becomes more automatic during initial learning. It is concluded as a reduction in the need to regulate and self-monitor the ongoing movements consciously [7]. Maquet [269] research demonstrated the premotor cortex activated during initial implicit motor sequence learning and the subsequent REM sleep episode, after which an improvement in motor performance was observed. This involvement of the premotor cortex in sleep-dependent motor sequence memory consolidation has been confirmed later also in Nitsche et al. [309] study, where activity in the premotor cortex was correlated with REM sleep duration during the post-training night [81]. The premotor cortex plays an important role in sleep-related motor memory consolidation processes [184, 185, 186]. It is crucial for ensuring communication between sensorimotor and associative networks for optimal motor behavior's implementation. Specifically, during early learning sequence with the transformation between the different coordinate frames (such as spatial and motor). It coordinates developed transformation maps that are consolidated by a sleep to optimize overnight motor sequential behavior [218, 234].

Sleep has empirical data for its crucial role in memory consolidation, for procedural and motor memory domain, with the influence of post-learning sleep on behavioral and neural correlates of motor memory and declarative memory consolidation $[130,209,268,330,393,446]$. Here memory consolidation is the process by which newly acquired memories are transformed into enhanced and more stable memory traces [106, 137, 277]. Motor learning is known to take place during task practice and between training sessions in the absence of any further practice [206, 207], where that important period is a time window for occurring the motor memory consolidation. Sleep-dependent consolidation processes can be activated if learning occurs to elicit hippocampal activation during training [218]. Motor memory consolidation is characterized by enhancement and maintenance in performance over an interval, including no further practice, but also by a reduction in the fragility of a motor memory trace after its initial acquisition [350]. The consolidation of a newly learned motor skill 'a' can indeed be disrupted when a human is trained on a competing task ' $b$ ' immediately after initial learning. It is a retroactive or retrograde interference effect, where the learning of a task ' $b$ ' interferes with the consolidation of the previously learned task ' $a$ '. 
Whereas a post-training time-window of approximately $4-6$ hours for sensitivity to such retrograde interference has been revealed for motor sequence learning [233, 234, 442] and motor adaptation [52, 237, 384]. The transfer of grosser motor sequential knowledge seems to depend on time rather than sleep per se [150]. The specific of forming up psychophysiological automatization processing of motor - memory movement consolidation during 4 hours has been revealed in independent empirical evidence [52, 190]. These research data of interference effects presence are not strictly limited to within the motor system. They testify of occurrence and of interference effects presence specified to both working and short-term memory, which means that both these temporary types of memory do have limited capacity for memorizing processing. It's the crucial cue for determining the size of a music work for possible learning and memorizing in the targeted musical performance form within 4 hours (or a shorter period of learning training the music material) from the initial a-vista reading of musical notes' text and with volume belonged to short-term memory capacity. Brown and Robertson [55] research revealed that a declarative memory task doesn't interfere with procedural memory consolidation (implicit sequence learning) oversleep. Thus sleep can help protect memory from potential interfering effect when two tasks differ in nature. It also facilitates the consolidation of specifically learned motor sequential material [218] and motor sequence performance levels achieved at the end of an initial training session - before a sleep - influence subsequent sleep-dependent consolidation [9, 454], with empiric evidence in children [454] and older adults [219]. The presence of sequential information in the motor engram [37] is the condition for sleep-dependent memory consolidation, with behavioral studies showing sleep-dependent improvement of performance on sequential material [349, 400], and by neuroimaging data showing "reactivation" of sequence learning-specific brain regions during post-training sleep [318]. Here the hippocampal system is involved in sleep-dependent consolidation in the processing of sequential information [124, 204, 239].

The acquisition of a new motor skill requires learning different aspects of the task simultaneously, with sequence learning including at least two processes - 'spatial' and 'motor' [185]. Spatial learning is referred to as perceptual [305], abstract [162], or effector-independent representation [25]. It represents the goal of the series of movements that need to be executed under allocentric [77] or extrinsic [460] coordinates. The motoric learning [458] is referred to as intrinsic [460], effector-dependent [162], and movement-based skill realized under egocentric coordinates [77]. Imagined or observed sequential movements are also consolidated by sleep [101, 430]. Cohen et al. [77] influential study revealed, that the consolidation of the motoric representation is time-dependent, whereas the consolidation of the spatial representation is sleep-dependent. Also, the consolidation process for explicit learning is sleep-dependent, whereas implicit learning is time-dependent $[80,105,131,349,400,455]$. Later studies demonstrated that sleep consolidates the abstract representation, and enhances the representation for both implicit [316] and explicit [5,6] motor sequence learning, where consolidation of the perceptual aspect of sequential learning with monitoring a temporal sequence is facilitated by sleep [252, 434]. Thus, the time-dependent consolidation process has additional improvement during sleep.

Sleep preferentially consolidates motor sequence memories that have been reinforced or "tagged" [138, 293] during initial training. Song and Cohen [398] research revealed that the manipulation of the practice schedule for the development of abstract motor "schema" during initial training [371] is activated the sleep-related consolidation processes following explicit motor sequence learning [99]. Also, sleep-related consolidation can be boosted when sounds associated with the sequence learning process (such as music work's recording content) are presented during post-training sleep, where the perceptual component of learning can be reinforced during sleep [16, 80, 81, 374]. Reactivation of hippocampal activity during such post-learning sleep has a crucial role in the consolidation of hippocampal-dependent declarative memory [319, 340]. This cue might be important, especially when fresh memorizing concerns unknown earlier musical work's content. An additional effect of sleep on motor memory consolidation is influenced by the complexity of the learned motor tasks. Kuriyama et al. [241] demonstrated larger enhancements in memory performance when the motor sequence was longer and performed by two hands, as compared to a shorter and performed by one hand. It revealed evidence in independent motor imagery studies confirmed this finding for explicit learning [100] and implicit learning [286], which is an important cue for synchronic bimanual professional musical instrumental activity. All physiological symptoms of mental fatigue at the level of the feeling of increased drowsiness, falling asleep or dullness of consciousness, which occur during memory effort, testify to the increased intense activity of the body at the physiological level and are an indication to immediately stop the exercise of musical performance, with the most optimal form of rest in the form of a nap, after which it is worth doing physical activity within the possibilities and availability. 


\section{BIOLOGICAL SPECIFICS OF KINESTHETIC AND EMOTIONAL MEMORY FOR MPM}

Functional lateralization of motor memory got evidence in empirical studies. Here right and left hemispheres differentially process sensory information, control movements, and use different mechanisms for storing information in memory [38, 51, 74, 171, 199, 423]. Scientific data revealed functional lateralization of the organization and coding of movements [51, 303], and sensory asymmetry determined by various properties of neural networks in the hemispheres [156]. Thus the neurophysiological mechanism can be the basis of mental processes for motor activity. Here specific brain lateralization of different functions for 'hand encoding' and 'hand motor memory' [39] become as imposed tendencies conditioning the character and specificity of 'memorized learning' with each hand, which affects the quality of synchronic training with both hands. Thus it is a fundamental condition for the organization of training and exercises for the musical performance of vocal or a musical instrument in the field of reproductive classical musical art. It dictates the direction of the effectiveness of the professional training of each human, taking into account the diagnosis of his hemispheric profile for this type of activity.

Right hemisphere (left arm):

- specializes in preparing hand movements, statics, and planning new movements, which includes tasks requiring complex spatial movements [51,295].

- specializes in more static aspects of movements and static problems mainly regulate the process of reaching the final position during movement [170, 173] and the internal representation of spatial relations [38, 199, 423]. - provides an initial assessment of spatial relationships, preparation of movement, the creation of new programs for performing movements, and spatial regulation of movements in the course of their execution. - forms a holistic concrete description in which, based on the description of the details, an image is created from sub-images, with the activity of non-linear neurons.

- is mainly associated with the analysis of 'past and present' [423].

- specializes in positional coding of positions with preserving accurate metric information [40, 41, 43, 170, 173, 254, 257, $359,367]$, with activity of the parietal region [190]. This coding is an important principle of the functioning of the brain when organizing movements, taking into account the desired position of the arm or body [35, 128, 331]. A change in the space of targeted movement can be described by a vector characterizing the amplitude and the direction of movement.

Left hemisphere (right arm):

- specializes in the movement of automated targeted, dynamic actions, with the presence of mechanisms for storing sequences.

- is predominant in the choice of the purpose of movement and the organization of sequences of movements of the left and right hands, identified in studies with positron emission tomography [40, 41, 43, 162, 163, 170, 171, 173, 178, 190, 254], also in clinical studies by Harrington and Haaland [169, 170, 171, 172, 173, 178]. This is due to the specifics of identifying the rules for organizing sensory information that determines the position of movement goals [41, 254].

- specializes in the reproduction of complex and less ordered time intervals of finger movements, which also proved during transcranial stimulation of the motor cortex [65].

- specializes in more dynamic aspects of movements (fine motor control, sequences of movements), motor tasks related to cognitive (cognitive) activity [38, 51, 162, 178, 199].

- mainly regulates the process of the trajectory of motion [170, 173], ensures the implementation of a sequence of targeted automated actions with monitoring of sequential responses, error correction, and precise control of such motion parameters as force, speed, and length.

- forms the mechanism of spatial-frequency analysis with the activity of linear neurons, mainly associated with the analysis of 'future' [423].

- specializes in vector coding of movements with the relationship between objects $[38,41,43,45,46,51,171,173,178$, $199,236,254,256,289,333,370,391,429]$, with the activity of the dorsal premotor cortex controlling the sequences of movements [190]. The neurons of the premotor cortex have receptive fields that move with the hand [164] and encode targets in systems that are motionless relative to the hand [63]. The arm region in the premotor cortex receives inputs from a specific region in the parietal cortex, where the target also encoded in the arm coordinates [73]. - activated for motor activity associated with higher levels of regulation of movements providing complex semantic correction of movements following the 'target desired' future movement. Here, the motor system selects the magnitude and duration of muscle force pulses so that the arm moves to the desired distance according to the desired amplitude of movement [48, 151, 152, 289, 370]. 
The function of the left hemisphere is organization of a sequence of movements with the identification and use of early previous information about the spatial ordering of sensory information, with the identification of rules and coordination of complex motor individual actions in one whole movement [44, 112, 178, 260]. That leads to the organization of new motor skills, including hand movements. The mechanism providing the formation of action based on the internal idea of the desired position in space is also essential here when the motor system modifies the characteristics of muscle length-tension so that the equilibrium point of interaction of the agonist and antagonist corresponds to the desired position [128]. Here, the parietal cortex is the main structure ensuring the accuracy of movements and the formation of internal representations of space. It is activated during the implementation of imaginary actions associated with conscious activity, related to the regulation of targeted hand movements, sequences of movements, and skills to work with tools [72, 90]. The issue of coding the abstract rules in the central nervous system is extremely relevant also for manual motor activity in the performance of music by the body. According to positron emission tomography, the execution of actions with the left-hand causes activation of both hemispheres, and the execution of actions with the right-hand causes activation of only the left hemisphere [162, 163] - more precisely, the left dorsal premotor and parietal regions [162, 163, 170, 173, 190], this regularity was also revealed earlier by A. R. Luria [262]. When working with the right hand, the coding prevails in the vector system. Whereas when working with the left hand, then vector and position coding are used simultaneously. Moreover, methods for processing information for the left hemisphere develop in ontogenesis later than methods for processing information for the right hemisphere [126]. For instrumental musical performance in the field of classical music art, it is crucial to take into account the advantage of the left hand in regulating synchronous musical playing with two limbs, with additional possible difficulties for performing movements by the right hand if they do not coincide with the target movements of the left hand. For strings and keyboards, the motor activity of the right hand should be adapted to the left hand regulating the musical pitch movement of music, which is characterized by positional coding. Therefore, learning the functions of the vector regulation of the movement of music is a separate complex function of this hand, which is not peculiar to it on the original biological soil.

During the learning process of a new motor sequence, there is required execution of the correct order of movements with simultaneously optimizing sensorimotor parameters such as trajectory, timing, velocity, and force. These components are crucial for the kinesthetic - artistic efficiency of music performance (vocal and music instrumental forms), specifically for classical music reproduction processing. Here are crucial the internal models of movement activity [210, 211, 193, 324, 465] - i.e., structural models used to plan and control the actions of the central nervous system [153]. The topology of actions that are related to the cognitive aspects of sensory information processing is also important here [317, 355].

The internal models:

1. cause sensory-motor integration and organization of movements, training, and higher cognitive functions thinking and consciousness [193, 210, 211, 324, 465].

2. provide for the transformation of planned actions into motor commands, from the desired motor behavior to the motor command [210, 211].

3 . in the process of organizing movements, they include a plan of the necessary action and take into account the parameters of its motor implementation based on information about the current state of the motor system and the parameters of the object. Here N. A. Bernshtein [34] defined the information on the spatial ordering of motion targets as the process of programming motion based on the comprehension of motor tasks. According to his research, based on information about the desired consequences of the movement, motor teams are formed that are required to implement a specific target movement. They also ensure the translation of the "semantic program of movement" into the "motor program of movement" [34]. Here, the predictability of movement is associated with aspects of higher-level motor behavior. For musical performance in the field of classical music art, the following levels of the system for regulating the construction of movements become most important: 3.1. The level of synergy (thalamo-pallidal) is key to the automation of motor skills. It provides actions that require precise coordination of complex movements that are rhythmically repeated in time and cover the limbs with the body. 3.2. The level that determines the complex semantic correction of movements following the target desired future movement - all complex musical actions and skills are credited here.

4. can interact in various ways to form a wide repertoire of behavior [210, 302].

5. are crucial for motor learning because they allow a comparison between the predicted and actual consequences of a movement, and thus for the assessment of movement error that is used to guide learning.

6. are instantiated in the Purkinje cell - parallel fibre complexes, where information about motor plans arrives from the cortical motor system, and additional climbing fibre system communicates error signals from the inferior olive that code discrepancies between planned and executed movement and determines modification of the existed internal model during learning process [24, 198, 210]. Here cerebellar mechanisms are important for modeling the sensory consequences of action and for computing error signals relevant for learning. 
In music performance production, it concerns simultaneous motor movement by hands and whole body with different systems of muscles and organs of the respiratory system involved in the production of shaping the quality of extracted musical sounds.

7. are also neural networks with processes providing a synthesis of information from various sensory modalities, where sensory-motor integration and organization of movements occur. These are neural structures that provide, among other things, regulation of sequences of hand movements [172]. According to studies by Mussa-Ivaldi [302], they regulate the activity of specific muscle synergies (that is, the set of muscles that provide a particular movement) at the level of the spinal cord. They ensure the execution of elementary movements [32, 302], and the activity of neurons determines the goals of the movement in the systems of the motor organ. Thanks to the system of mirror neurons, motor skills training arise through imitation, that is, observation and subsequent repetition of the action. Here, neurons of "relative coding" also perform an important function. In essence, they determine the preliminary stage of the organization of movements, which is transformed then into muscle-like coordinates, i.e., into signals addressed directly to the muscles of the executive organ. Variable motion parameters are defined here, such as a set of muscles and their activation pattern. It is based on external environment specifics, shape, position of the moving part of body, and motor task [195]. Moreover, various internal motor models, such as the structure of neural networks, can compete during training. Each target complex motor skill, transformed into a form of automatism and often used in life activities, is a type of neural network for a specific scheme of motor movements of a targeted nature and application. It explains the biological basis of the appropriate initial formation of targeted motor kinesthetic skills and techniques for the correct, necessary, and expected performance of a classical musical work.

In psychophysiological studies on the reproduction of a sequence of hand movements, errors tend to accumulate when the number of movements in the sequence increases [47]. The nature of the errors indicate different coding of the amplitude and the direction of movement [31,47], which is proved by lateralization of vector and position coding. Moreover, mechanisms of acceleration's regulation of movement's duration do provide the errors' correction of acceleration's amplitude. It allows to achieve the accuracy of the desired position in space for a moving arm. These biological data are especially important for the emergence of the properties of spatial motor errors during long-term techniques of a large number of notes at one motor technique, especially at medium and fast speed of music performance. The formation of motor skills is a multi-level process that activates the areas of the frontal and parietal cortex, subcortical structures (cerebellum, basal ganglia) [185]. There are learning processes associated with the development of a new motor team or with the use and improvement of a previously learned team [195]. There is an important role of associative activation with two entrances to the motor cortex: 1. from the somatosensory cortex necessary for the formation of new movements; 2 from the ventrolateral nucleus of the thalamus with a change in the synoptic efficiency of cortical motor neurons [18, 197, 212]. Two types of internal representations of motion sequences are manifested here: spatial sequences that cause abstract coding and are associated with memory, and motor sequences that cause effector-specific coding and are associated with the reproduction of motion [162, 185].

In the early stages of learning, prefrontal cortical areas associated with explicit learning are activated. In essence, these are the dorsolateral prefrontal cortex, motor zones of the right hemisphere, and extensive areas of the cerebellum [176]. The cerebellum receives sensory and motor information from both descending cortical pathways and ascending peripheral pathways [245, 291, 369] with strong connections to the parietal, premotor and frontal cortex [76, 104, 213]. It determines error correction and instantiates the formation of internal models that facilitate optimal performance and learning process in music's reproduction, where internal model is the structure of a set of input-output relations between motor commands with the predicted sensory consequences of that action [198, 298, 338, 385, 467]. The empiric data of neuropsychological studies, fMRI studies of human rule-learning, and computational modeling of cerebellar circuits reveal about the capacity to instantiate internal models [198, 210]. Here cerebellar-frontal circuits are involved in automatizing or developing internal models of cognitive behaviors, similar to the way cerebellar-motor circuits are involved in motor learning [24]. With the duration of the training, the activity of areas of the left hemisphere associated with motor activity increases. The front of the left hippocampus is responsible for implicit sequence training in the early and late stages of motor skills training [154]. With implicit learning, the lateral premotor cortex, the addition of the motor region of the left hemisphere, and the primary motor cortex are first activated, later cognitive loops including the basal ganglia and structures of the right hemisphere are activated [176]. Brain structures activated by implicit (unconscious) and explicit (conscious) learning are different. Still, empirical data by Cleeremans and Jimenez [75] prove the possibility of a unified coding system for implicit and explicit information, which leads to more effective control identifying and distinguishing the symptoms of these types of training. 
The formation of motor skills includes memorizing and reproducing sequences of movements, is carried out in the process of memorizing an already known sequence, with repeated reproductions [406, 431, 432], requires solving motor and cognitive problems associated with the organization of the required set of movements [249]. It becomes possible when the internal motor program of movements stored in the memory is deployed [33, 254]. It causes a decrease in errors in subsequent reproductions. It is improved during training and determines the relative times and relative activation forces of muscles. The parameters of such a program are formed for specific conditions and values of the external environment, they determine and establish the absolute times and forces of muscle activation, which are necessary for performing a sequence of movements. It allows us to achieve the goal of the movement quickly with minimal involvement of consciousness [183, 249]. It is important here to memorize a repeating sequence of movements, which are key in the formation of motor automatisms during repeated repetitions of sequential movements. Whereas learning processes for both hands proceed in a similar way [42], which facilitates the upbringing and formation of hand synchronization in playing a musical instrument.

In training and the formation of motor skill, it becomes important not only the "automatic" performance of memorized movements under the control of the teacher during implicit (unconscious) training but also the understanding of the actions performed during explicit (conscious) training since the structures of stored information do change during training [33]. And there is a period of consolidation of a memorable trace of motor skill after learning a new specialized movement. Then training for another movement violates the consolidation of the first skill if it is implemented and conducted immediately after the first training. Consolidation occurs gradually over 4 hours [52]. In the process of consolidation, a change of activated structures occurs. Before consolidation at the beginning of training, maximum activity is observed in the prefrontal areas, and after the consolidation is observed in premotor, posterior dark areas, and cerebellar cortex [190]. In the process of motor training, there is formed a program with two schemes in the motor cortex - for new coordination and for specialized downward influences that provide inhibition of interfering natural coordination. Here, the primary role of the motor cortex in the inhibition of natural coordination interfering with the implementation of the generated movement. Moreover, the control of the motor cortex over the implementation of complex coordination is also maintained after the stage of automation of movement [23, 194, 195, 196]. Because a new movement can partially reproduce natural or previously learned motor coordination, but the scheme of the generated movement itself can be the opposite of natural coordination, which in such cases should be inhibited in the learning process. When reproducing the known movements, the main burden falls on long-term motor memory [255], which is formed up during the consolidation of a memorable trace of motor skill for 4 hours, and then in the night sleep cycle after exercise and memorization of motor skill. However, the formation of new motor skills requires the participation of short-term motor memory, which manifests itself over 4 hours before the transition to long-term motor memory. It is caused by the capacity increasing with growing [248] and decreasing with aging [365], the accuracy of remembering the parameters of movements, and the speed of remembering these parameters [394, 469] decreasing with aging [14].

The motor kinesthetic sequence learning is conditioned by parallel interacting processes, such as internal model formation and sequence representation. They are formed up by specific mechanisms of the cerebellum, basal ganglia, and motor cortex. Here the striatal system learns predictive stimulus-response associations and is critical for motor chunking. The function of the cerebellum is to acquire the optimal internal model for sequence performance in a particular context and to contribute to error correction and control of on-going kinesthetic movement. Motor cortex acts to store the representation of a learned sequence as a part of a distributed network, including the parietal lobe and premotor cortex [323]. The sequence learning in behavioral studies' data occurs in partially separable stages: an early phase where changes are rapid, a consolidation phase where the sequence becomes resistant to interference, and a slow-learning phase where movement timing, kinematics, and dynamics are optimized [52, 208, 384]. The major brain networks involved and engaged in sequence learning in neuropsychological studies' data are motor and premotor regions, basal ganglia, cerebellum and parietal cortex $[113,114,185,385,457]$. Here cerebellum and parietal cortex, as motor system's structure, may contribute to learning by integrating motor and sensory information to update existing motor programs or create new ones [290, 385, 466]. The sequence learning in behavioral - neuroimaging studies' data can be separated into spatial (sequential) and motor control components [22, 155, 185, 362, 363, 450] supported by different brain mechanisms [161, 313, 321, 322, 402]. It is conditioned by parallel, interacting processes, such as error correction, internal model formation, stimulus-response association, and sequence representation, that are instantiated in specific cerebellar, striatal, or motor mechanisms. The motor activity in music concerns qualitative changes in performance production and quantitative changes in the learning process. The learning efficiency of motor sequence tasks and activities, in the overall time to execute the musical sequence, concern decreasing the number of errors with acceleration of changes in reaction time in response to a cue. 
The 'motor sequence learning' is the acquisition and optimization of a novel series of inter-related movements. Here the order of movements during initial acquisition is learned with motor parameters optimization during continued practice by resulting in accurate and efficient musical work's performance. In contrast, sequence order is acquired by focusing on implicit and explicit mechanisms [19, 457]. A newly fresh acquired sequence of movements is slow, inaccurate, and jerky, whereas a well-learned motor sequence is accurate and smooths. It might take place in a single music training session on the part of well-learning musical work. Here short period of practice changes the performance condition, which can be related to an enhanced neural representation of the sequence and more efficient implementation. Here the brain must encode a set of optimal movements with concrete implementation parameters, where the learning of motor-sequences and the adaptation of motor-movements co-occur. Since acquisition and representation of sequential order and motor optimization are partially separable, but the learned sequence is a dynamically changing and integrated representation [313, 315].

Motor-learning concerns faster and slower learning processes. Here a more explicit spatial - sequential component is learned more quickly, whereas a more implicit sensorimotor component is learned more slowly. These components of the motor-learning process are conditioned by partially separable neural mechanisms that are optimized over different time-courses [321]. For the programmed kinesthetic organization of musical performance, there are crucial critical keys to the musical performance efficiency disturbances in case of its' changes after the period of initial automatic preparation in the beginner state of musical exercise. It concern especially the breathing cycles of musical phrases (in vocal and wind instruments), the spatial manual movements on selected string height positions with time divided organization on bow activity (in string instruments), the fingering organization in the architecture of simultaneous hands' activity with appropriate targeted moment of pedaling movement with selected or synchronous legs activity (in keyboard instruments, where the exercise activity on the piano should be adapted to the weight of the keyboard similar to the external instrument for concert conditions), the body muscle architecture position of selected and simultaneous hands' activity (in percussion instruments). Biological conditions of respiratory system development and bone growth in childhood should be taken into account for possible kinesthetic and motor difficulties on this basis, with the particular adaptation of methods and forms of musical exercise during this period of human development.

Emotional memory:

1. belongs to the classification of memory in the category of memory content (with types of figurative, motor and verbal-logical), according to the organization of memorization, it is an integral type of semantic and procedural memory $[116 ; 125]$.

2. provides reproduction of the emotional state without displaying 'emotio-genic' stimuli in images or verbal symbols, without the participation of verbal-logical memory. Here emotional roles are particularly crucial in emotionally enhanced memory functions, i.e., the process of encoding new information containing emotional components [376, 436]. 3 . is provided by the structures of the limbic system that make up the integrative mechanism of emotional behavior. Here the limbic system takes part in the formation and activation of emotional reactions that arose during the early life experience. Fibers from neurons of the reticular formation, transmitting signals from all senses to the structures of the limbic system, go to various areas of the cerebral cortex, responsible for the emergence and awareness of emotional experiences [270]. Additionally, the amygdala plays a crucial role in emotional processing [15]. The insular cortex, the secondary somatosensory cortex, the cingulate cortex and nuclei in the tegmentum and hypothalamus are the brain regions that regulate attentional focus by integrating external and internal inputs to create emotional feeling states [95].

4. is the body's process of reproducing a previously experienced emotional state in conjunction with a memory of the situation that caused it and a subjective attitude to it.

5. promotes the development of imagination and creativity [438].

6. has the main characteristics, such as the speed of formation, special strength, and spontaneous reproduction. They determine a significant role in the behavior (verbal and non-verbal) of a person in his actions, mood, and relationships with the surrounding world [165].

7. simply refers to the notion that very emotional events are more often memorable, where emotional stimuli consume more attentional resources than non-emotional stimuli [376, 426].

The presentation of an emotional stimulus gives priority to its processing. It is easier storing and processing emotional stimuli relative to neutral $[15,111,214]$, with the difference in the work of attention when remembering the emotional performance of music. It is associated with an increase in the activation of the emotional stimulus representation in working memory as an effect of attracting attention by the emotional stimulus [26, 312, 334, 341]. At the automatic primary level, the emotional content of the stimulus is extracted, and its importance assessed. Here, processing does not require additional attention resources and is carried out at the subcortical level, using the amygdala [79]. 
Then controlled processes take place, where emotional information takes precedence in the competition for attention resources, with additional activation of the frontal cortex. Emotional 'appropriation' of attention is therefore related to the processing of information at a controlled level. Here, in the formation of the emotional and intonation content and meaning of a musical work, emotional reactions or emotional states arise based on a conditioned-reflex emotional memory with the participation of figurative and verbal-logical memory. Emotional memories and impressions are recorded almost instantly and involuntarily. They provide replenishment of the subconscious sphere of the human psyche, and information is reproduced from the emotional memory [247; 344 ]. Emotional characteristics may facilitate processing [26, 334, 341], but it can also disturb [265; 345; 456] with too much intensity. Here in Kensinger and Corkin [214] studies, activation of the prefrontal cortex areas in the processing of emotional and cognitive information was indicated. The cognitive [157] region is the dorsolateral prefrontal cortex, whereas the emotional [409] region is the abdominal-medial-orbital-frontal prefrontal cortex. There is a specific relationship between these regions, where the activation of the emotional area is accompanied by a decrease in the activation of the cognitive area, which is the neurological correlate of competition between different information modalities.

Attentional and motivational components of emotion have been linked to heightened learning and memory [320, 380]. During the initial perceptual stage, attention is biased toward emotional information. Stimulating selective attention increases for emotional information to become encoded in LTM storage associated with an indirect influence on perception and attention that regulates selective sensory processing and behavioral determination [436]. Motivational components promote learning and enhance subsequent memory retrieval with generalizing new events consequent to adaptive physiological changes. Primary emotional systems do regulate associative learning and memory (classical conditioning and emotional habit) by the mediation of emotional networks. This includes basal ganglia (basolateral and central amygdala, nucleus accumbens, thalamus, and dorsal striatum) and medial temporal lobe (MTL), including hippocampus as well as the entorhinal cortex, perirhinal cortex, and parahippocampal cortices that responsible for declarative memories. Secondary learning and memory do regulate emotional feelings in relation to environmental events that subsequently refine effective solutions. Such higher cognitive functions do operate within the cortical regions, including the frontal cortex for awareness and consciousness functions such as thinking, planning, emotional regulation, and free-will (intention-to-act), which do mediate emotional feelings. Cognition is an extension of emotion where emotion is an extension of feeling homeostasis. These processes are integrated with the secondary processes and do reach a mature level (higher brain functions) to better anticipating and yielding cognitive control of emotion.

Amygdala and hippocampus are synergistically activated during memory encoding to form an LTM of emotional information [116, 247, 284, 344]. Here emotions influence the formation of a hippocampal-dependent memory system [325], exerting a long-term impact on learning and memory. They powerfully modify cognitive appraisals and memory processes. The innate emotional systems interact with higher brain systems where emotional state influence on cognitive ramifications. The amygdala's involvement in emotional arousal processing strengthens the memory network by modulating memory consolidation during memory processes (encoding, storage, retention) that contribute to the emotional enhancement of memory [265, 284]. Labile memories of newly learned information become stabilized and strengthened to form long-lasting memories [282]. Here activation of the basolateral complex of the amygdala is conditioned by emotionally arousing events, which appear to modulate memory storage-related regions that influence long-term memories [283]. Additionally, direct projections from the amygdala to sensory cortices during emotional processing do enhance attentional mechanisms. They might allow the parallel processing of the attentional (frontoparietal) system [436]. Thus the amygdala activation is associated with enhanced attention [426], where emotional content is remembered better than neutral content. According to the hemisphere functional specialization of emotions: 1. the right hemisphere is responsible for the perception, expression, and processing of positive emotions, more involved in the regulation of intellectual activity; the left hemisphere is responsible for perception, expression, and processing of negative emotions, more engaged in the regulation of emotional response [189, 216, 388]. 2. the right hemisphere processes information simultaneously and holistically; it has a specific synthetic processing method; the left hemisphere processes sequentially information entering the brain is associated with the serial organization of movements. It is characterized by an abstract analytical processing [217, 468]. These properties are manifested in the learning and memorizing of musical material and regulate the nature of the quality work on it. Here Damasio's approach to James-Lange concept development defines emotions as a set of changes in the state of the body and brain that respond to specific perceptual contents caused by the imagination. In response to an emotional stimulus, somatic conditions with physiological changes arise in the body. These bodily changes range from changes in the internal state to changes in skeletal muscle and muscle facial expressions. Responses to an emotional stimulus arising in the brain cause the central nervous system to release certain neurotransmitters with a change in signal transmission from the body to somatosensory regions [270]. 
A procedural (implicit, unconscious) emotional soldering causes the memorization of movements and the preservation of motor skills [308] in conditions of emotional activation, enhancing attention [328]. Therefore, forming the emotionality of stimuli, one can directly change attention, improve memory, or a sense of remembering [387]. The emotional experience of music ensures its naturalness in the intonation and sense of breath of musical phrases in the structure of a musical work. It is the core of regulated and adaptable musicality to the content of specific music. It determines artistic performance appealing to listeners and conscious recipients of classical music. It gives the background and emotional content to a musical text that creates a psychophysiological basis for the specific body and psyche states in learning and playing music. In this condition of memorizing the music (i.e., with emotional activation), it produces the ease of performing final purposeful music from memory. Here, adapting the musical performance repertoire to the emotional and aesthetic preferences of the performer's music ensures the optimization of the compatibility of the emotional content of musical works with his emotional needs and emotional naturalness. It minimizes the risk of experiencing deeper and saturated emotional states different from the emotional compatibility of an individual. It includes the formation of clinical symptoms of split personality [353], which is characterized by the disintegration of 'me/myself' sphere and uniqueness naturalness space. It is conditioned by performing musical repertoire with the different state emotional music content from the predisposition and emotional compatibility of the musical performer. Also, Lerner et al. [250] fMRI research revealed that the perception of music with eyes closed causes changes and a direct connection with areas of the brain that process emotions. Therefore there is a deeper activation of the areas responsible for emotions with closed eyes, which is a reasonable independent case for realizing that condition during memorizing music processing.

\section{BIOLOGICAL SPECIFICS OF ATTENTION AND MEMORY CAPACITY FOR MPM}

The memory for musical performance (i.e., musical performing memory MPM) is characterized by the dominance of arbitrary, selective attention with a temporary organization of its functional optimization. A. R. Luria [17, 30, 66, 231, 261] defines voluntary attention in double direction - as a process of isolating elements essential for mental activity (selection of information), and as a process of maintaining control over a clear and organized flow of mental activity. Therefore attention is characterized by selectivity as filter warning of flooding of consciousness with irrelevant unnecessary, inappropriate information [373]. Here the mechanism of the dominant focus of attention is summarizing and accumulating incoming impulses while suppressing the activity of other centers and giving behavior a certain orientation $[68,427]$. The hippocampus is a filter that transmits only new signals and sifting out information elements already stored in the memory [361, 372, 419]. It determines the target conscious regulation of musical performance as programmed behavior at the level and in the form of the executive function. Here at the psychophysiological level, an increase in the degree of synchronization of the electrical activity of the alpha range is detected with the targeted directional expectation of visual, auditory, and tactile stimuli in situations of target intellectual activity [56, 230, 381, 382]. Arbitrary attention is determining and conditioning the strength and selectivity of memory with accuracy and detail perception, as well as the direction and productivity of mental activity - thereby the quality and results of all voluntary human activity, which includes musical performance as a programmed action.

In hemispheric functional specialization of attention [314, 379], the right hemisphere mainly provides wakefulness and concerns involuntary attention. It determines the presence of symptoms of mental fatigue in the circadian rhythm of wakefulness. In contrast, the left hemisphere refers to voluntary attention and mainly determines the specialized organization of attention related to specific activities and tasks. It determines the presence of symptoms of mental activity and the optimization of the concentration of attention on their fulfillment in the circadian rhythm of wakefulness. It also concerns short-term memory in memorizing a musical work. The optimal level of mental productivity is achieved at the beginning of such a circadian rhythm and then decreases until the moment of the temporary end of such a cycle, where it is necessary to observe rest. According to psychophysiological data, a person's voluntary attention during monotonous work is maintained with its optimal concentration for an average of 15 to 20 minutes. Then it dissipates, and there is supposed to make a pause or to switch to another type of activity or do an exercise of musical work that strengthens the earlier assigned material. This period is shorter in children with impaired attention and increased mental fatigue and is more authentic in children with increased mental endurance and "memory absorption" in the absence of mental overload. If the work with the study of a musical work is fascinating, it forms a deep motivational interest, does not cause special difficulties for the perception and organization of the kinesthetic activity of the target musical performance. After-random attention has become, and the stage of distracted attention may come later or do not appear until the moment of exhaustion, with the required biological break. After-voluntary attention is associated with the goal of the activity, is supported by a conscious interest, does not cause volitional efforts, remains focused for a longer time, and does not cause fatigue due to voltage. Then is available to deal and training with the earlier learned material. 
Neurophysiologist Kleitman [223] revealed up advanced the day-time biological rhythm as a «basic-rest activity cycle», of about 90 minutes average period during wakefulness. It is based on a common generating mechanism with sleepiness and wakefulness during the day's mental activity. This period increases with age from $50-60$ minutes in infants, through $60-70$ minutes in school children, until $90-110$ minutes in adults [224], with an impressive amount of data collected from later studies on humans which do certify these regularities [225]. With including these data, the time-period for learning and memorizing new kinesthetic sequences of intentional targeted musical work's performing is translated into around $3-4$ trials. It concerns the time reserved for the automatization of primary learned kinesthetic activity movements. The more hard and difficulty occurs during primary learning and memorizing session, the more short part of musical piece is recommended to be taken for its memorizing and mastering at the final required level of musical performance. Including the interference process that might be observed by learning selected new parts of different musical works, there is not recommended to memorizing different musical works during a single day training session. Whereas different parts of musical works with mostly its repeated content and minor small changes should be done and worked out during a single day training session, with preparing the separate memory map for the differences as adds of all repeated musical content in musical work. The process of attention, along with perception, determines the occurrence and functionality of memory, reflects the concentration, is depth-ness in memorable activity, as targeted musical performance, and affects its effectiveness [477]. Therefore, the features of perception and attention directly affect and form the memory's content of musical performance.

The cerebral functional asymmetry of the music's aural perception is important here, which directly affects the state of aural musical memory. Neuropsychological studies of R. J. Zatorre and P. Belin [471, 472, 473, 474] using positron emission tomography revealed: 1 . the dominant role of the right hemisphere for encoding musical pitch information; 2. the dominant role of the left hemisphere for encoding musical rhythm information. It reflects the differences between right and left hemispheres in the peculiarities of their interaction in the perception of music, with empirical confirmation of the mutually competitive organization of the grouping of musical material by pitch and rhythm parameters [177]. The human's auditory cortex shows functional differentiation in that different areas are selectively sensitive to temporal or spectral acoustic features of music. These differences are presented between cortex regions in two hemispheres, as well as between cortical structures connecting both hemispheres. The functional independence of both hemispheres determines the differentiated variants of the state of interhemispheric interaction in the auditory processing of music and musical information, which form up different 'lateral profiles' of the working aural musical memory as a musical cognitive psychological process. This is directly reflected in memorizing a musical work.

Biological studies of memory do prove about psychophysiological limitations of attention resources in optimizing the information processing when it is perceived by different receptors, especially auditory and visual. It occurs due to the property of the selectivity of attention. The antagonism in music processes between writing and listening, or reading and kinesthetic performing is the result of the attention division [68], where instead of summating information across auditory, visual or kinesthetic modes, it becomes separated into different directions of perceptual processing. The focusing on signals of a certain modality (auditory and visual stimuli) is regulated by activation of the human sensory cortex in different ways. The cognitive and neural foundations of focusing attention on the information of one sensory modality, while ignoring the information in another sensory modality, do substantiate the biological principle of the competitive influence of sensory attention zones on each other. Competition of auditory and visual modality signals can occur both at the sensory and at the central processing level. At the sensory level, this is the mutual influence (modulation) of activity in the corresponding brain areas, when information from some sensory organs can modulate or suppress the response in those zones of the cortex that are responsible for other modalities. At the central level, this arises due to the mechanism of selective attention on certain stimuli for solving a specific target task, which regulates the process of isolating a target or a specific stimulus from the total flow of incoming signals of different modality. Here, the downward effects of attention do modulate the interaction of the sensory regions of the cortex by gating sensory information. This interaction improves the processing of one modality at the expense of another during selective attention and subsequently affects memory coding [202, 263, 294]. Here in psychophysiological studies it was proved, that the results of audiovisual integration were worsened when attention was directed only to the visual object [416]. Also fMRI data with the processing of mixed visual and auditory information, while focusing on one of these modalities with alternating signals of different modalities, revealed that auditory stimulation led to a decrease in activity in the visual cortex, and the presentation of only the visual signal deactivated the auditory cortex [243; 383]. Here might be an example, when we read a book with enthusiasm, the perception of surrounding sounds is suppressed, and there is a decrease in the activation of attention in other sensory modalities, because of what we may not hear the question asked us. Competition for attention resources and working memory is observed additionally within the limits of one modality. It manifests itself not only in relation to signals of different categories (for hearing, this applies to speech and non-speech signals) but also for signals within each of these categories [50]. 
These effects are determined by mechanisms of primary grouping in the attention selectivity with the proximity of signals characteristics and attention focus. It contributes to the formation of perceptual units and the allocation of the target signal from the background in a complex scene conditions [53, 203]. In the distribution of attention resources, this is manifested mainly in the processes of spatial grouping during visual perception and temporary grouping during auditory perception [27, 28, 53, 68]. An example of the hearing is the possibility of distinguishing the speech of one target speaker based on the individual characteristics of his voice in a "party" situation the simultaneous speaking of a large number of people - i.e., cocktail party aural perception effect [53]. In music, this concerns the allocation of instrumental parts in orchestral performance (timbre characteristics, melodic coherence). Additionally, pitch and rhythmic information [62, 102, 390] or timbre [263, 337, 449, 464] may enter into dual relationships and mutual influences at the perception of its complex perceptual organization. It applies not only to perception and listening, but also to control of performance in professional public presentations or recordings. The limitation of resources also affects the reduction of auditory control's accuracy, and emphasis can go then to the kinesthetic form of control [301, 410, 436, 437].

In the process of memorizing completion of a musical work, the psycho-physiological resources: 1. are aimed at visual attention in the process of reading a vista of musical notes from a sheet; 2 . do concentrate brain processing for information at this level; 3. do reduce concentration for processing the information received in kinesthetic receptor with participation of analytical thinking (the formation and extraction of each musical note by separately) and synthetic thinking (the production of notes' group with musical meaning of music intonation's elements); 4. do reduce the concentration of attention for auditory control of each extracted note read a vista from the music sheet of a musical work. It purposefully substantiates the advisability of initially memorizing music on every day, while studying its content (i.e., 'reading a vista' the musical notes from a music's sheet), in the volume of a piece of a musical work within the scope of the information available for immediate direct memory. Such a procedure accelerates musical material processing at the kinesthetic, auditory, and emotional levels, with a more correct and faster-selected set (combination) of motor actions for the formation of each musical note and intonation-al sounding of the music in its target (concert) performing form. In this case, human's predominant auditory, visual, or kinesthetic cognitive style in perception and learning may manifest as well as the effects of auditory dominance in children [203, 304, 351, 392].

Attention (as working memory) resources are conditionally limited to few perceptual units, which can be enlarged due to perceptual unification. Then they become an object of attention (as figures distinguished from the background) and, therefore, as units of memorization. They can be as musical elements of a work - from notes through bars to semantic phrases. A preliminary memorizing of a musical work by such fragments and their subsequent combination can facilitate the music notes' content processing with a more controlled training of performance. It also contributes to highlighting and more conscious studying with closed eyes [54, 238, 253, 258, 386, 411]. Additionally, according to the biological laws of perception, the processing of information at the auditory and kinesthetic receptors in the state of closed eyes, on the example of music performance, leads increasing the severity of these receptors [326] and more deep conscious bodily perception (i.e., proprioception) and sensation of music, as well as its formation and experience at the bodily level [222, 250]. For memory mechanisms, it significantly improves control and regulation of the state of body (i.e., proprioception) and regulation of motor actions as well as the emotional experience of music during its performing. It is available during the perception of musical notes text as semantic material for its conscious memorization with reproduction and control by other receptor modalities [222, 301]. For effective memorization of musical works, it is crucial here to have the stage (periods) of the exercise in a state of closed eyes, like eliminating the attention over-load by visual receptor in the process of learning and memorizing music with a deeper internal immersion in the feeling of own body activity (i.e., proprioception). It speeds up the process of finding the right movement actions for their subsequent transition to automated functions for producing the specific effect or form of music performance.

In the presence of a transitional stage of a musical exercise of a concrete musical work's fragment, there is the necessity to engage the learning in the state with open and then with closed eyes, both in the transitional version of musical exercise and in the target final form of musical performance, in the first attempt with open and second attempt with closed eyes. It is also important to take into account that listening to music with closed eyes causes a direct connection with brain areas that process emotions [250]. Since this accompanies quality and acceleration accompanies the quality and acceleration of memorization a musical work due to the presence of this form of training stage. Various forms of human cognitive activity, accompanied by the activation of voluntary attention, are characterized by a certain type of neuronal activity, clearly comparable with the dynamics of voluntary attention, depending on the type of perceived and processed information for the memory's condition. In the hippocampal neural networks, the nerve cells are distinguished, as neurons of novelty and identity [96, 188, 412]. Receptor signals from neurons of novelty and identity do affect oppositely for activating and synchronizing brain systems. 
Novelty neurons allow for highlighting new signals. Their background impulse and activation increases under the action of new stimuli of different sensory modalities. They are connected to separate zones of the cerebral cortex, which form exciting plastic synapses on novelty neurons. Thus, the impulse activity of novelty neurons increases under the action of new stimuli. By taking into account the differentiated level of excitation, the novelty neuron response is selectively and gradually suppressed as the stimulus repeats, and additional activation in it disappears while maintaining the basic background activity. Identity neurons receive impulses from different sensory modalities through inhibitory plastic synapses. The background activity in identity neurons is suppressed under the action of new information, while, on the contrary, it is activated under the action of usual information. A new stimulus stimulates the activating brain system, excites novelty neurons, and inhibits identity neurons. At the same time, the well-known familiar stimulus stimulates the inhibitory brain's system, excites identity neurons, and inhibits novelty neurons. Therefore, in the process of programming (i.e., memorization) the performance of a musical work, primary novelty neurons forming up neural networks that are then activated by secondary identity neurons during subsequent refinement of the programming behavior of musical performance, especially after the consolidation's stage of long-term memory's content during and after a night's sleep [96, 188, 412]. Attempts to retrain a musical work in the form of reprogramming behavior do entail psychophysiological disturbances, when the slightly changed behavior's content is still familiar to the brain and, therefore, identity neurons are mainly activated. In this case, the level of psychophysiological activation of novelty neurons in a state of relearning the programming behavior of musical performance is lower from the level of activation of these neurons in the time moment of the initial study of musical work's memorization. These patterns are an independent objective source of the cause of difficulties in the free mastery of the musical work performance in a state of testing the experience of retraining. Therefore, various forms (types) of performing a musical work should be studied and learned from the very beginning of processing the material of its content with programming behavior for this target activity.

Neural networks, as memory's content, lend themselves to a dynamic change of their activation at the level of attention processing and activation of memory's temporal types. Temporary and gradual memory's filling with information material is characteristic at the biological stage of the information's transition from sensory and working through short-term to long-term memory, especially along the path of memory traces' consolidation during the sleep. Here Oberauer [311] treats short-term memory as an area of long-term memory that contains information with the highest level of activation (and thus the most available). Attention is: 1. mediated between storage and processing the information; 2. oriented to the information stored in long-term memory while performing a cognitive task with the involvement of working memory when various information is activated in the working memory. Additionally, Ericsson and Kintsch [125] defined the long-term working memory as memory type of a set of 'retrieval structures' in long-term memory, that enable access to the earlier obtained relevant important information for current tasks or mental activities. Here 'plane' working memory is organized into two structural levels. The first concern long-term memory activated representations, with theoretically no limited capacity, while the second concern the focus of attention with limited capacity for activated representations [82]. Working memory, which is part of long-term memory at the level of new information processing, activates long-term memory at a lower level than in the repeated processing up the information memorized earlier and stored in long-term memory as a result of the memory consolidation process [82, 125]. Therefore, initially higher activation of working memory arises with less activation of long-term memory, and then in subsequent sessions of a musical exercise with higher activation of long-term memory as its component. Also, the automation of motor skills, which takes place in the time interval of 4-6 hours, is forming up another their psychophysiological form at the musical performing level. They become lighter and more manageable in the freedom of musical performing after the initial period of their formation in the primary time interval for musical work's memorization.

Working memory was proposed by A. D. Baddeley and G. J. Hitch [21] in 1974 and confirmed empirically independently in N. A. Cowan [86, 87] psychological data, and in A. Guida, F. Gobet, H. Tardieu, S. Nicolas [166, 167, 168, 220] physiological data. It is based on the development of R. C. Atkinson and R. M. Shiffrin short-term and long-term memory model. It is allocated as part (share) of long-term memory and short-term memory, which contains only information that is inactive processing [2] with the attention's participation. At the same time, the remaining shares of short-term and long-term memory are involved only in the process of storing information and do not entail the manipulation or organization of material stored in memory [82, 83, 89]. Such a combination ensures the efficiency of access to information necessary for solving current problems under conditions of combining the functions of its storage and processing [433], which are necessary for the current momentary mental activity [116], which is especially characteristic of the process of musical work's fresh memorizing. 
Working memory, and thus fresh biological memorization: 1 . is an immediate, instantaneous, and primary memory with encoding of new, unknown, just received information or material's stimulus content; 2 . is based on the psychophysiological process of capturing stimulus information and its initial retention in memory [20, 49, 288]; 3. arises in a person with focused attention participation and without preliminary, additional efforts, without repeating the stored information and its meta-memory strategic processing. It is due to the properties of physiological, biophysical, biochemical, information and energy systems of the molecular and cellular levels at the brain level for behavioral reality [12, 29, 246, 377, 397]. These are genotypic and innate functional brain systems. They provide the basis for perception and appropriation of information at the level of coding and decoding in new material's direct memorization process. The storage of information at this memory's level does not depend on the subjective and personal regulation of this process. This type of memorization has a mechanical character with observing the possibility of its opposite effect, such as forgetting [67].

Forgetting is characteristic at the biological level due to the effects of interference and of $\mathrm{H}$. Ebbinghaus 'forgetting curve' principle (also called as 'learning curve') that causes filtering of memory in the state of its temporary overflow due to the excess amount of entering information. It has a time function of information loss in the form of sharply falling lines such as "L" for forgetting of meaningless material or "\" for forgetting semantic material. It is determined by a decrease in the level of information retention in memory over time when information is lost due to failure to perform actions for its preservation along the path of active use during repetitions or mnemonic processing [118]. This is a condition for memorization processes improvement due to the formation of understanding as specially organized mental actions. These are mental operations that lead to good memorization, identified in cognitive psychology, and related to such actions as grouping, strong points, mnemonic plan, classification, structuring, systematization, schematization, recoding, completion of memorized material, serial organization of material, association [67]. At the same time, the 'forgetting curve' tends to decrease memory for newly learned knowledge if it does not fit into the amount of information that belonged to short-term memory [366] Moreover, the volume of stored information at an automatic level and not included in this phenomenon is fairly proportionally close to the amount of information belonged to working memory. This means that the forget curve refers to the process of loss of accessibility to material coming out significantly from the volume of working memory. Additionally, the theory of forgetting concerns also the possibility of reducing the amount of forgetting information by actively mnemonic processing at frequent time intervals, during the period of its fresh primary study and assimilation. It means that longer temporary processing of a specific amount of freshly learned information: 1. makes it more appropriate at the cellular level of the brain memory mechanisms; 2. increases the likelihood of its transformation into long-term memory during the sleep cycle after a day of its active or primary learning. The separation between working memory and short-term memory was established empirically, also by the 'forgetting curve' principle. Here short-term memory forgetting is due to its limited volume and duration of information processing, related to proactive interference, identified by G. E. Muller [259, 300], with loss of information perceived later and to retroactive interference with loss of information perceived earlier. Interference means self-imposition [187, 215, 287, 404] and associative inhibition [259, 300, 346] of information. In this case, the information included in working memory capacity is not influenced by interference, which confirms further the difference between working memory and short-term memory [433]. For the musical performance's field for musical works' effective memorization, the effect of proactive interference from the position of the material's duration on the music's structure is more significant. However, the effect of retroactive interference also causes damage to the material learning earlier (musical work's part) in case of its memorization inhibition due to memorizing a new musical material in a one-time interval of music's learning. It occurs in condition when the total memorized size of a musical work exceeds the volume that belonged to short-term memory capacity.

Short-term memory capacity, which determines the possibility of its transformation into long-term memory, can be checked and established in the time periods at the evening moment immediately before falling asleep and in the morning moment immediately after waking up. It is due additionally to the biological law of the spontaneous natural increase of alpha brain waves' activity in those time intervals of biological circadian brain rhythms. They determine the transition from the conscious to the unconscious, with an increased state of brain learning with a faster speed information processing and its moving into long-term memory, with an increase of serotonin production [306]. In a situation where the amount of information reproduced on the night before falling asleep is more than in the morning after waking up, then we get the amount of information transformed into long-term memory and its outgoing shared part beyond the short-term memory capacity. It proves indirectly also about how much information learned on the day before bedtime can be extracted naturally and spontaneously without additional conditions after recalling an earlier memorized material. In a situation where the amount of information reproduced on the night before falling asleep is less than in the morning after waking up, then we get the amount of information transformed into long-term memory and shared part of information subject to an inability to retrieve from memory on the day of training before bedtime, which most often indicates mental fatigue and congestion for memorable functions' optimization. 
In a situation where the amount of information reproduced on the night before falling asleep is the same as in the morning after waking up, then we get optimization and regulation of memorable functions at the meta-memory level (conscious ownership and memory management), without any violations in storing information and retrieving it from memory when the storage step facilitates a fused stages' transition from short-term memory to long-term memory. That amount of information entering into long-term memory does not interfere with the subsequent new information entering the sensory and working memory on the next day of studying new content of a musical work. It is complemented in time for the whole integral memorable structure of musical content belonging to long-term regulated memory. With respecting the rule of the musical exercise with closed eyes regulation of music performing at a proprioception level, it lends itself to deeper control and conscious body's management with the emotional experience of music to form automatic skills for its targeted performance. It causes a decrease in fatigue and energy mental costs for music memorization. It additionally forms the minimization of stage fright state with negative consequences due to the feeling of a lack of full control over musical work performing processing. It eliminates loss of control's state during the musical exercise by transferring the artistic work to its external music performing (concert, recording). At the same time, the automation of the behavioral skills of musical performance determines their manifestation in different conditions of performing music from memory, including for the state of a public performance of a musical work. When, for example, the effectiveness of auditory monitoring and control for quality of musical performing is limited or reduced [136, 301, 356, 410, 420, 448].

Empirical data in cognitive psychology were obtained about memory span for amount of 3 - 4 units for 11 - 12 ages with neuropsychological data about sensory aural unit's duration for 3 seconds [84, 85, 88, 147, 148, 200, 280, 281, 310, 311, 360, 413, 414, 415, 462, 461, 463], wherein young children this volume is less. Thus, an empirical level with the time interval of 9 to 12 seconds and musical size of 6 bars measures was obtained, as an initial indicator of working aural musical memory span [117], which at the biological level determines the effectiveness of musical work's memorization For music's memorization efficiency, the quantitative size of musical work for an exercise in one training session should be selected carefully, taking into account: 1 . the minimum durations of parts of a musical work that make up the meaningful musical sense with and music's intonation phrasing; 2. the amount of information that becomes unforgettable for short-term memory as a form of temporary memory according to the 'forgetting curve' principle as very close and similar in proportion to working memory span with a slight increase; 3. mental, intellectual processing, and shaping the music's performing affecting five channels of information receipt in the body and its control. \{1) cognitive - semantic - visual as the initial and shortest; 2) semantic - motor with possible different transitional stages for the formation of the final performing skills; 3) semantic - auditory based on sound control of performance due to motor activity; 4) emotional - intonation superimposed on a cognitive content of musical notes' channel that determines the semantic artistic performing of music and affects the shape and quality of the motor sphere of musicality and freedom of music performance; 5) proprioception with elements of increased perception in closed eyes' state.\}

Attention resources (as a synonym for working memory process in term of its span), determine the inevitability of high-quality processing of the minimum brief part of a musical work (phrase) for the feasibility of its most faithful and targeted studying at the initial stage of a musical exercise. This can be for age from 11-12 years old to an adult, on average up to 15-20 seconds of music's sounding in the target performance for middle or fast speed (tempo), and up to 30 - 40 seconds of music's sounding at a slower pace. These time parameters are narrowed accordingly for an earlier age and expand accordingly for humans with the dominated and advanced ability of memory absorption. According to psychology's law of individual differences, also a significant increase in music's volume memorized in the daily cycle is possible and affordable. However, this is primarily due to 1. technical complexity of musical work's performing. 2. its intonation-al content for music's emotional expressiveness. The more complex and time-consuming content of musical work for its targeted final concert performance, the more justified the narrowing of the size (musical bars' amount) for the detailed music's processing with memorization. The final size can be established by the parameters of the reproduction from memory just freshly memorized music of the same day at the night before sleep and on the next day in the morning just after waking up, with a period of observing own-self daily for at least 20-25 days, with an optimal period of up to 1,5 months. By taking into account age-related changes in the human cognitive sphere, such monitoring should be carried out every 1-1,5 years. Musical works having structurally repeating fragments of musical content, for classical musical notes' literature, in a condition of same performing its' content should be learned in less of their exercises, with separate playback of fragments of their differences - according to the present scheme. Here at the level of memory trace's organization, a hierarchical scheme of such music content's unit arises. The upper level represents the same musical notes' content, whereas the lower level describes the different musical notes' content.

$\underline{\mathrm{A}} \quad$ [The content of the musical notation 'A-B_A-C_A-D_'].

/ \ The optimal form of music's memorization $\downarrow$

$\underline{\text { B C D }}$ [A__ as a separate part; B, C, D as additional selected parts studied together side by side in time.] 
In condition of target requirement for different performing the music's part 'A' its' content should be learned in all its repeating variations simultaneously, but separately studied (highlighted in a separate stage of the musical exercise). Thus, learning them according to the different nuances of their performance, which should be processed at the emotional and motor kinesthetic levels using the same music's semantic content (i.e., music notation). To optimizing the memorization of music, it is advisable to process such an action within the framework of one session of a musical exercise, at least for $2-4$ variants of different performances of the same music's content. Then at the night sleep's stage with consolidation that content into long-term memory, it becomes as memorized differentiated forms of musical performance. In the case of technical difficulties associated with the time parameter of a musical work, an auxiliary version of the music exercise should fit (approximate) to equal parts of its target performance, expanded in time. On the example of the content of music notation according to the time parameters (shares of the target tempo) 'A-B-C-DEF' - the optimal form here of the auxiliary version of music's memorization by the time-division might be such 'A-C-E' or 'A-D'. Since the temporary part 'A' of the initial exercise is then decomposed into temporary parts 'A-B' or 'A-BC' of the target music's performing. Then on the rhythmic temporal version (in terms of tempo), there is no risk of forming a separate commemorative program for the content of music of different temporal diameters, which does not have a direct arrangement on the target form for performing a musical work.

According to the biological rule for the automation of motor reflexes in the daily processing of new memorized content of a musical work, as part of a new fresh learned musical material, the number of holistic reproductions (repeats) by exercising such material in an intermediary auxiliary educational form(s) should not exceed the amount of reproductions (repeats) in the target correct music's performing (for the final form of a musical work's performance). By taking into account, the temporary automatism organization of motor skills, including small ones for a specific music work's content, the selected fragment of a musical work must be learned and memorized completely in the target musical performing within 4 hours from the moment of the initial exercise with its content. For condition of when the duration of musical exercise in one training session does not exceed from 30 to 120 minutes, the part of musical work's content must be set and selected so that it can be worked out through and memorized completely for the target music performance. Including characteristics of the emotional sphere in organizing and regulating the emotional experience of music, which is required to be present at all stages of musical work's memorization, it is inevitable to work out such music's fragment which is a part of holistic semantic act of its emotional and semantic content. For an analog with speech material, it can be compared with the allocation of individual words or their group, making up a meaningful phrase or a short sentence. Including time limitations of memory capacity, the studied musical work's part should fit into the amount of information that can be consolidated in long-term memory in the sleep cycle. Also, newly learned material should be targeted for play in the later evening before bedtime and in the morning after waking up. Under circumstances of the brain's mental overload by different types of information perceived in daily activity, the goal is to narrow the volume of the studied material of musical content or to divide the studying of new material every second day. After each night sleep cycle, with the primary consolidation of the music content in long-term memory, subsequent work with its content goes into the stage of strengthening the earlier learned content with facilitated repetitions and closer to conscious automatic regulation of its performance. Then less and less auxiliary reproductions (repeats) are required. Also, the level of musical exercise approaches improvement and refinement of the target musical performing with optimization of the emotional sphere and physical body organization of each musical note or a group of musical notes in a single breath or reflex skill. Thus, complex, masterly virtuosic works of classical musical literature become accessible to ergonomic learning with memorization completion in several days (weeks). In the condition of such musical work's fragments with repeatable content, their capacity for memorizing storage is narrowed to the size of the primary sample pattern of such content. Then they become less busy at a memorable level despite their long-lasting sounding, which allows them to reduce and to narrow the time interval required for memorizing them. It leads to faster free mastery of such virtuosic musical works' content. By that result, they are available for more rapid mastery of them at required targeted music performance's level, with minimization of negative symptoms of bolti-ness, feeling bored or tiredness of musical work in case of its over-performing. After a holistic memorization completion of musical work, it is necessary to play it at least once a day to preserve the freshness of memory for its content. With daily mental workload, this mode can be expanded for 2 to 3 days. This principle also applies to producing all needed or required versions of musical work's interpretation in professional musical performance, except for own-self personal performing as the most natural and spontaneous (such as for: 1. competitions, auditions, historical, musicological concerts for stylistic interpretation. 2. music's teacher. 3. different acoustic conditions. 4. musical recordings agencies). It determines the possibility and conditions for maintaining the maturity of artistic performance within the framework of professional musical property of elastic artistry. In professional musical performance activity at the completed memorization state, the whole musical repertoire is also required to be realized by daily reproduction (even once) to preserve the condition of memory's freshness with its strengthening on the biological cell level. Otherwise music is forgotten over time fragmentarily firstly then holistically, so it requires an increase of time for subsequent re-memorizing. 


\section{METHODOLOGICAL TIPS OF MUSICOLOGICAL DATA FOR MPM}

The views of musical methodologists on musical memory are determined by the experience and observation of professional musicians and also the own activity of professional musical performance, which belongs to the scientific fields of musicology and musical pedagogy. These data are used at a practical level in the professional training and teaching technologies of classical musical performing art. According to these data, by far, the most reliable and basic form of performing memory in musical performance is the unity of auditory and kinesthetic components, and visual memory only supplements them [264, 421]. Additionally, in the analysis of the processes of memorizing a musical work, constructive memory is highlighted as the performer's ability to understand well all the smallest details of the thing being learned, in their isolation, and the ability to collect them together $[274,275]$. It was noted that musical memory, like the memory in general, plays an important role in the field of all mental work, is more difficult to artificial methods of development, and makes more or less reconcile with what each given subject has by nature [348]. It fundamentally concerns the biological properties of the memory capacity. Here, the strength of memorization is inversely related to the volume of memorized material. The more cumbersome the material for memorization is, the smaller the percentage of it will remain and stored in memory. Therefore, it is better to memorize a large volume of text in dividing its' content into separate fragments, as for the semantic grouping, where each fragment is a logically completed semantic unit of musical material. It also includes semantic correlation. The basis of this technique is the use of mental operations to compare among themselves some of the characteristic features of the studied musical work. In addition, great importance for the development of musical memory is given to the preliminary analysis of work, with the help of which material is actively memorized, an understanding of the structure and mutual relationship of all parts of the material, as well as tonal plan of musical work [299]. It was emphasized that the method of analysis and the establishment of conscious associations is the only reliable way to memorize music, in which the first stage of work is to force yourself to do certain things; the latter is not to interfere with things being done on their own [264]. Also, work on memorization should be reasonable and facilitated by auxiliary moments in accordance with the characteristic features of the work, its structure and expressive means [235]. These means form the essence of music, that is, the emotional impact, where music is primarily characterized by logic with a sequence of deeply conditioned sounds [127]. At the present time in the methodology of musical pedagogy, the most widely disseminated and verified data is based on primary historical, musicological data about stages of working with the music established by Josef Hofmann (1876-1957). This statement made up with separate methodological thesis 'Piano playing' (edited in 1908) and 'Piano questions answered' (edited in 1909), which have been combined as 'Piano playing: with piano questions answered' (edited in 1920 by Philadelphia: T. Presser publisher with Music University of Toronto contribution, 346 pages). Stages, described next, do include: 1. work with musical notes' text without music instrument; 2 . work simultaneously with musical notes' text and music instrument; 3. work with music instrument without musical notes' text; 4. work simultaneously without musical notes' text and music instrument. The later data of musical pedagogy revealed in professional musical practice refers to them.

At the first stage, the process of familiarization and primary memorization of a musical work is carried out on the basis of a careful study of the musical text and presentation of its' sounding by using internal hearing. The preliminary stage of memorizing music is always internal and analytical hearing since musical memory uses the material that is provided by it, and incomprehensible and undivided cannot be remembered. There are also cases when a musical work that was only read by the eyes was learned [364], and the development of the ability to learn a musical work from musical notes without an instrument is an increase in the professional skill of the musician. At the second stage, after the first production of musical work and mental acquaintance with it should be aimed at grasping and understanding its general artistic meaning. At this stage, there is noted about sketching familiarization with the musical work, for which it should also be produced (performed) in the target executive form. With that, it's possible to take care of the accuracy of execution gradually in its selected parts. Here after the first acquaintance, a detailed study of the musical work begins: semantic strong points and difficult places are identified, with revealing convenient fingering, respiratory phrasing, the grouping of notes for individual bow movements. Here in learning forms, awareness of the features of the work continues, its plan is clarified within the framework of which the development of the artistic image is carried out. It is important here to constantly think about what is performing as a guarantee of successful completed memorizing since well-remembered is the only content that is well understood [94]. Also, the material is remembered gradually, so at this stage, it is also necessary that the potential artist should not have any dark (unconscious) elements of the text in the musical work. The most appropriate in this stage of preparation may be the principle of "see-hear-perform", which ensures the full inclusion of internal hearing as one of the most important foundations of musical memory, but not "see-perform-hear", more focused on the development of kinesthetic components of musical performance with the accompaniment of auditory control [221, 240]. Here completed memorization should be dominated by arbitrary memorization based on the rational use of special mnemonic techniques and rules, also careful thought over what is being learned. 
When completed memorization is not a special task of the performer, and in the process of working on the artistic content of the work, it is remembered without violence against the memory, or it is not remembered if the memorization is not required, then a tricky bench is created. Many musicians fall into it by memorizing the new content of music until it is remembered. Such a decision is doubtful because of uncontrolled and unconscious memorization [327]. Since the higher feeling, sensory and mental activity is in the process of learning work, the faster it is at completed memorization. Therefore, for proceeding the completed memorization process most efficiently, it is necessary to include in activities of all musician's analyzers, such as: 1. peering and peering into the musical notes, it can be remembered as a visual text and then during the performing from memory through imaging it mentally in own eyes; 2. listening to the melody, singing it separately in a voice, it can be remembered as an aural content; 3. additionally, there might be used the technique of "tapping" or "slamming" rhythmic pattern of musical work or its elements; 4. "plunging" fingers into the texture of the musical work, it can remember in the kinesthetic motor background; 5. noting the strong points of musical work during its performing activity, there might be added a logical memory based on remembering the logic of a plan's development. Here, an important point is the consistency of this diverse activity and its integration with gradual collection of the learned elements and fragments in a single sequence, which may be accompanied by a return to beginning or previous segment of musical work [240]. With according to the psychophysiology of attention, it is also necessary to take breaks between intense mnemonic work and other activities. After the musical material is learned, the formed tracks are strengthened. If, after mnemonic work, some kind of psychological overload is allowed, then the learned material will be forgotten due to retroactive inhibition, i.e. "acting backward". Similarly, when after strenuous mental activity starting working on a new musical work, that requires increased attention, it will be difficult to memorize completely due to proactive inhibition, i.e. "acting forward". Therefore musical material should be learned in a state without earlier mental overload by another type of activity, as well as without later mental overload after studying it.

At the third stage in the process of performing a musical work from memory, there is further strengthened in auditory, motor, logical memory. The associations to which musical performer resorts to find greater expressiveness of the musical performance have great help in memorizing completion. Here the involvement of poetic associations for enhancing aesthetic feelings is a tradition in musical performance. And a combination of audible sounds with extra-musical images and representations, that have a similar poetic basis, evokes emotional memory. When a musical work has already been memorized completely, it needs regular repetitions to be fixed in memory, since neural traces are blurred under the influence of new life impressions [470]. But beyond certain limits, an increase in the number of repetitions does not improve memorization, and the repetition of the material countless times for better memorization is unconditionally condemned by modern didactics, both in general and in musical pedagogy. Here the work of a musician of any specialty is most fruitful when it is performed with full mental focus, i.e. can only be maintained for a certain time. And in musical exercise, the quantitative side matters only in combination with the qualitative. At the same time, the speed and strength of memorization are associated with a rational distribution of repetitions in time, where completed memorization, distributed over a number of days, will give longer memorization than persistent memorization in one exercise session [364], what is especially crucial for memory capacity limitation. It does not turn out to be more economical since it is possible to learn a musical work in one day, but it is quite often forgotten just tomorrow, which is quite similar to the law of memory capacity. Therefore, it is better to distribute the repetition for several days and it is not recommended to take too long breaks during completed memorization since in this case, it can turn into a new memorization processing. When completing memorizing, the adjacent techniques of passive and active repetition, in which the material is first played on musical notes, and then immediately an attempt is made to memorize it, have been proved themselves well. Then the risk is reduced when trial performing from memory is in many cases accompanied by inaccuracies and errors that require from the musician to have increased auditory control, focused attention and collected will to fix the mistakes made [299]. But special attention is required to place of 'docking' of individual passages and episodes. And even when the musical work is well-learned by memorization, it is recommended do not break up with the musical notes' text, since repetition by musical notes should be regularly alternated with playing from memory. Here, an additional huge benefit for the controlled memorization and recollection of a musical work is brought by the game at a slow pace at least once a day. This helps to refresh musical performances, to understand everything that can slip away from the control of consciousness over time [407].

At the fourth stage, a musician of any specialty can only be convinced that he remembered the musical work when he was able to restore it mentally, to trace its development without looking at the music notes, and to realize its smallest constituent elements. This is the most difficult way to work with musical performance, and it is often said that it is tiring mentally. Nevertheless, by alternating the mental reproduction of work without a musical instrument and with a real performing on the instrument, the musician can achieve extremely lasting memorization of the musical work. Here, before extracting the first sound, the general image of the musical work already lives in the performer. Based on the general image, the musician sends every detail of performing art [275]. 
During the performance, the musician on all the most important facets should have in his consciousness a synthesized summary of what he has already played and at the same time a kind of extremely concise compendium of what remains to be played. Mental repetitions of the musical work develop a concentration of attention on auditory images, which is so necessary during a public performance, enhance the expressiveness of musical performing, and deepen the understanding of musical composition. Achieving a special strength of memorization among musicians is ensured by repeatedly performing a piece of music in the mind, at the level of musical-auditory representations. In the final analysis, the variant where the musician hears the necessary sound inside himself, then performs and checks the result with traces in the internal auditory memory can be considered as a confident and artistic performance. However, in reality, these processes are very fast and the musician does not always have time to realize them. Here, often during a musical performance, singers and performers playing on musical instruments with an unfixed system can make significant deviations from the correct intonation, not fixing them through the current 'auditory control', but focusing more on kinesthetic sensations [356, 410, 436, 448]. It is also important to note that, given the 'artistic matter' of the musical works, these deviations are in most cases not noticed by the audience, but can be detected by the performers themselves when listening to the recording of their performance. Despite these limitations, the development of the ability to think ahead of time is a basic potential for high professional musician performer $[68,240]$.

\section{CONCLUSION}

In the methodological literature on musical pedagogy for singing and specific musical instruments, as well as the tradition of the nature of master courses for professional musicians, the thesis about targeted work on a musical work in the state of its memorizing-learning completion is often voiced. Then a condition of fluent freedom of manipulating the content of a musical work and changing the performance of its components arise. The essence of effective training of musical performance, with a state of constant deep drawing into the need for musical exercise, consists in satisfying the need for curiosity and communing with music in an appropriate daily dose, with simultaneous objective satisfaction and a sense of control over every attempt at musical exercise. It conditions the lack of boredom from musical performance training. It inhibits and reduces the risk of the phenomenon of over-playing, over-training, and over-mental load transferring re-training, and mental load from a musical work content. It removes the danger of developing the phenomenon of professional burnout associated with a musical performance. It creates the biological basis of the primary form of working with a musical work at the stage of its memorizing - learning completion process. This auxiliary stage is the key to the further quality of the study and mastery of the fluent freedom to play a musical work. Moreover, what and how has been over-learned and memorized-completed initially - it remains the primary basis for the musical work performance processing.

According to the biological laws of learning and memory, all overhead subsequent forms and variations remain crowded out by the original form of musical work exercise training on the brain organization basis of music performance. It is especially important for mechanisms of kinesthetic habits automatisms. Since they are formed up daily after every one-time exercise session of working with part of a musical work, it creates limitations and complications for the conditions of re-learning musical work in the direction of its target faithful allowed professional performance. There is a necessity to take into account the biological laws of time limitations for volume of new studied information that entering into the memory, and this condition arises the possibility of temporary learning that is not stored in memory and lost in time. This is an area of unconscious learning that does not lend itself to complete control but imposes a state of loss of full and holistic ownership over the quality of musical work performing when unconscious memorized parts that interfere with the formation of the target version of music performance comes outside.

Observance of the biological laws of time limitations and the characteristics of learning and memory, as well as the formation of motor actions and habits for musical performance, creates the conditions of musical exercise efficiency for the ergonomics of memorizing-learning music with preserving the freedom of its performing without losing a lively artistic character just from the beginning of the processing of its content and musical meaning. This condition is possible to acquire at the brain level only from the just initial study of memorizing learning of a musical work in its target version of sound and performance with temporary periodic learning training options as purely auxiliary, without forming them as dominant and squeezing the next target form of music performance. The future belongs to ergonomics of musical performance and musical performing memory in the field of classical music's art. It lies in medical research on the physiological, morphological, motor, and psychiatric data and indications to establish the daily time volume of a musical exercise that is solvable to maintain professional musical health. Additional scientific research data and methodological recommendations in the fields of neuro-dietetics, neuro-didactics, and neuro-psychology will allow us to optimize the ergonomic technologies of professional training in the musical performance of classical music art and the ergonomics of self-training of this activity for mature and independent musicians to optimize the functionality of the musical brain in gerontological and geriatric contexts. 
Finally, video monitoring of the recording of a music exercise session in a size of 3 to 6 hours allows us to control and adjust the effectiveness of the exercise process. On this basis, the length and quality of time moments that favor or inhibit the effectiveness of musical exercise might be determined. During determining the periodicity or cyclicality of specific stages of musical exercise, there is a possibility to identify psychophysiological episodes of fatigue syndromes with this activity and to designate deliberate breaks during musical exercise. The methodology of this technology is based on applied behavior analysis. It enables the reduction of undesirable behaviors and the strengthening of desirable behaviors by means of behavioral psychotherapy to correct or improve musical exercise. It also allows you to identify exercise music behaviors that are harmful or desirable to a specific man who is professionally learning music. By taking into account complaints submitted by the student and the teacher regarding the process of professional music education, it becomes possible to interpret in video monitoring as desirable or undesirable evidence for the musical exercise's effectiveness. It allows different or selected behaviors of musical exercise appearing in video-monitoring recording to be defined for the needs of the diagnosis of an individual musician. It also gives greater efficiency to select possible disease entities or clinical changes for learning disorders revealed during musical exercise, especially of mixed activity's nature, with taking into account ICD-10 and DSM-V medical classifications of disorders.

\section{REFERENCES}

[1] Abel, T., Havekes. R., Saletin, J. M., Walker, M. P. (2013). Sleep, plasticity and memory from molecules to whole brain networks. Current biology, September, 23 (17), R774-R788.

[2] Aben, B., Stapert, S., Blokland, A. (2012). About the distinction between working memory and short-term memory. Frontiers in psychology, August, 3, art. 301, 9 p.

[3] Adams, N. B. (2004). Digital intelligence fostered by technology. Journal of technology studies, Spring, 30 (2), p.93-97.

[4] Ager, A. L., Borms, D., Deschepper, L., Dhooghe, R., Dijkhuis, J., Roy, J. S., Cools, A. (2019). Proprioception: How is it affected by shoulder pain? A systematic review. Journal of hand therapy, August, 9 p.

[5] Albouy, G., Fogel, S., King, B. R., Laventure, S., Benali, H., Karni, A., Carrier, J., Robertson, E. M., Doyon, J. (2015). Maintaining vs. enhancing motor sequence memories: Respective roles of striatal and hippocampal systems. Neuroimage, March, 108, p.423-434.

[6] Albouy, G., Fogel, S., Pottiez, H., Nguyen, V. A., Ray, L., Lungu, O., Carrier, J., Robertson, E., Doyon, J. (2013). Daytime sleep enhances consolidation of the spatial but not motoric representation of motor sequence memory. PLOS One, January, 8 (1), e52805, 13 p.

[7] Albouy, G., King, B. R., Maquet, P., Doyon, J. (2013). Hippocampus and striatum: Dynamics and interaction during acquisition and sleep-related motor sequence memory consolidation. Hippocampus, November, 23 (11), p.985-1004.

[8] Albouy, G., King, B., Schmidt, C.M.D., Dang-Vu, T., Balteau, E., Phillips, C., Degueldre, C., Orban, P., Benali, H., Peigneux, P., Luxen, A., Karni, A., Doyon, J., Maquet, P., Korman, M. (2016). Cerebral activity associated with transient sleep-facilitated reduction in motor memory vulnerability to interference. Scientific reports, October, 6. art. 34948,14 p.

[9] Albouy, G., Sterpenich, V., Balteau, E., Vandewalle, G., Desseilles, M., Dang-Vu, T., Darsaud, A., Ruby, P., Luppi, P.H., Degueldre, C., Peigneux, P., Luxen, A., Maquet, P., 2008. Both the hippocampus and striatum are involved in consolidation of motor sequence memory. Neuron, April, 58 (2), p.261-272.

[10] Albouy, G., Sterpenich, V., Vandewalle, G., Darsaud, A., Gais, S., Rauchs, G., Desseilles, M., Boly, M., Dang-Vu, T., Balteau, E., Degueldre, C., Phillips, C., Luxen, A., Maquet, P. (2012). Neural correlates of performance variability during motor sequence acquisition. Neuroimage, March, 60 (1), p.324-331.

[11] Albouy, G., Sterpenich, V., Vandewalle, G., Darsaud, A., Gais, S., Rauchs, G., Desseilles, M., Boly, M., Dang-Vu, T., Balteau, E., Degueldre, C., Phillips, C., Luxen, A., Maquet, P. (2013). Interaction between hippocampal and striatal systems predicts subsequent consolidation of motor sequence memory. PLOS One, March, 8 (3), e59490, 15 p.

[12] Aleksandrov, J. I. (1989). Psichofiziologiceskoe znacienie aktivnosti centralnych i perifericeskih neironov $v$ povedenii. ed. Moscow, Nauka, 208 p. [original: Александров, Ю. И. Психофизиологическое значение активности иентральных и периферических нейронов в поведении. (Psychophysiological significance of the activity of central and peripheral neurons in behavior.) Москва, изд. Наука. 208 с.]

[13] Altgassen, M., Koch, A., Kliegel, M. (2019). Do inhibitory control demands affect event-based prospective memory performance in ADHD? Journal of attention disorders, January, 23 (1), p.51-56.

[14] Ananjev, B. G. (2002). Celovek kak predmet poznanija. ed. Saint-Petersburg, Piter, 288 р. [original: Ананьев, Б. Г. Человек как предмет познания. (Human as a subject of knowledge.) Санкт-Петербург, изд. Питер. 288 с.] 
[15] Anderson, A. K., Phelps, E.A. (2001). Lesions of the amygdala impair enhanced perception of emotionally salient events. Nature, May, 411 (6835), p.305-309.

[16] Antony, J. W., Gobel, E. W., O’Hare, J. K., Reber, P. J., Paller, K. A. (2012). Cued memory reactivation during sleep influences skill learning. Nature neuroscience, August, 15 (8), p.1114-1116, 10p.

[17] Apcel, W. J., Cygan, V. N. (2004). Pamiat' i vnimanie - integratory psihiki. ed. Saint-Petersburg, LOGOS, 120 p. [original: Апчел, В. Я., Цыган, В. Н. Память и внимание - интеграторы психики. (Mетоry and attention psyche integrators.) Санкт-Петербург, изд. ЛОГОС. 120 с.]

[18] Asanuma, H. (1989). The motor cortex. ed. New York, Plenum. 386 p.

[19] Ashe, J., Lungu, O. V., Basford, A. T., Lu, X. (2006). Cortical control of motor sequences. Current opinion in neurobiology, April, 16 (2), p.213-221.

[20] Azimov, E, G., Shiukin, A. N. (2009). Novyj slovar' metodiceskih terminov i poniatii. Teoria i praktika obucenija jazykam. Ed. Moscow, IKAR, 448 p. [original: Азимов, Э. Г., Щукин, А. Н. Новый словарь методических терминов и понятий. Теория и практика обучения языкам. (A new dictionary of methodological terms and concepts. Theory and practice of teaching languages.) Москва, изд. ИКАР. 448 с.]

[21] Baddeley, A. D., Hitch, G. J. (1974). Working Memory. In: G. A. Bower (ed.). The psychology of learning and motivation: Advances in research and theory. ed. New York, Academic Press, p.47-90.

[22] Bailey, J., Penhune, V. (2010). Rhythm synchronization performance and auditory working memory in early- and late-trained musicians. Experimental brain research, July, 204 (1), p.91-101.

[23] Balezina, N. P., Barga, M. E., Vasiljeva, O. N., Ivanova, N. G., Ioffe, M. E., Pavlova, O. G., Frolov, A. G. (1990). Issledovanie mehanizmov reorganizacii dwigatelnyh koordinacii pri obucenii. In: M. G. Ajrapetianc (ed.). Mozg i povedenie. Sbornik naucnych trudov. Institut wysshej nervnoj dejatelnosti i neirofiziologii. ed. Moscow, Nauka, 590 p., p.105-119. [original: Балезина, Н. П., Варга, М. Е., Васильева, О. Н., Иванова, Н. Г., Иоффе, М. Е., Павлова, О. Г., Фролов, А. Г. Исследование механизмов реорганизации двигательных координации при обучении. (Study of the mechanisms of reorganization of motor coordination when learning). I М. Г. Айрапетянц. (ред.). Мозг и поведение. Сборник научных трудов. Институт высшей нервной деятельности и нейрофизиологии. (Brain and behavior. Collection of scientific papers. Institute of higher nervous activity and neurophysiology.) Москва, изд. Наука, 590 с., с.105-119.]

[24] Balsters, J. H., Ramnani, N. (2011). Cerebellar plasticity and the automation of first-order rules. Journal of neuroscience, February, 31 (6), p.2305-2312.

[25] Bapi, R. S., Doya, K., Harner, A. M. (2000). Evidence for effector independent and dependent representations and their differential time course of acquisition during motor sequence learning. Experimental brain research. May, 132, p.149-162.

[26] Bargh, J. A., Chaiken, S., Govender, R., Pratto, F. (1992). The generality of the automatic attitude activation effect. Journal of personality and social psychology, June, 62 (6), p.893-912.

[27] Beck, J. (1972). Similarity grouping and peripheral discriminability under uncertainty. American journal of psychology, March, 85 (1), p.1-19.

[28] Beck, J., Ambler, B. (1972). Discriminability of differences in line-slope and line-arrangement as a function of mask delay. Perception and psychophysics, 12, p.33-38.

[29] Behtereva, N. P. (1974). Neirofiziologiceskie aspekty psihiceskoj dejatelnosci celoveka. ed. Leningrad, Medicina, 152 р. [original: Бехтерева, Н. П. Нейрофизиологические аспекты психической деятельности человека. (Neurophysiological aspects of human mental activity.) Ленинград, изд. Медицина. 152 с.]

[30] Behtereva, N. P., Nagornova, Zh. V. (2007). Dinamika kogerentnosti EEG pri vypolnenii zadanii na neverbalnuju (obraznuju) kreativnost'. Fiziologia celoveka, 33 (5), p.5-13. [original: Бехтерева, Н. П., Нагорнова, Ж. В. Динамика когерентности ЭЭГ при выполнении заданий на невербальную (образную) креативность. (EEG coherence dynamics during non-verbal tasks (visual) creativity.) Физиология человека, 33 (5), c.5-13.]

[31] Berkinblit, M. B., Feldman, A. G., Fukson, O. I. (1986). Adaptability of innate motor patterns and motor control mechanisms. Behavioral and brain sciences, December, 9 (4), p.585-638.

[32] Berkinblit, M. B., Fookson, O. I., Smetanin, B., Adamovich, S. V., Poizner, H. (1995). The interaction of visual and proprioceptive inputs in pointing to actual and remembered targets. Experimental brain research, 107 (2), p.326-330.

[33] Bernshtein, N. A. (1966). Ocerki po fiziologii dwizenij i fiziologii aktivnosti. ed. Moscow, Medicina. 349 p. [original: Бернштейн, Н. А. Очерки по физиологии движений и физиологии активности. (Essays on the physiology of movements and the physiology of activity.) Москва, изд. Медицина. 349 с.]

[34] Bernshtein, N. A. (1990). Fiziologia dwizhenij i aktivnost'. ed. Moscow, Nauka, 495 p. [original: Бернштейн, Н. А. Физиология движений и активность. (Physiology of movement and activity.) Москва, изд. Наука, 495 с.]

[35] Bizzi, E., Accornero, N., Chapple, W., Hogan, N. (1984). Posture control and trajectory formation during arm movement. Journal of neuroscience, November, 4 (11), p.2738-2744. 
[36] Blanco-Campal, A., Coen, R. F., Lawlor, B.A., Walsh, J. B., Burke, T. E. (2009). Detection of prospective memory deficits in mild cognitive impairment of suspected Alzheimer's disease etiology using a novel event-based prospective memory task. Journal of the international neuropsychological society, January, 15 (1), p.154-159.

[37] Blischke, K., Erlacher, D., Kresin, H., Brueckner, S., Malangré, A. (2008). Benefits of sleep in motor learning prospects and limitations. Journal of human kinesthetic, October, 20 (1), p.23-35.

[38] Bobrova, E. V. (2007). Sovremennye predstavlenija o korkowych mehanizmah i mezhpolusharnoj asimmetrii kontrola pozy. Obzor literatury po probleme. Zhurnal vysshej nervnoj dejatelnosci, 57 (6), p.663-678. [original: Боброва, Е. В. Современные представления о корковых механизмах и межполушарной асимметрии контроля позы. Обзор литературы по проблеме. (Modern ideas about cortical mechanisms and interhemispheric asymmetry of posture control. Literature review.) Журнал высшей нервной деятельности, 57 (6), c.663-678.]

[39] Bobrova, E. V. (2010). Mehanizmy sensomorotnoj koordinacii dvizhenij i pozy celoveka. Dissertacia biologiceskih nauk. ed. Saint-Peteresburg, IFRAN, 319 р. [original: Боброва, Е. В. Механизмы сенсомоторной координации движений и позы человека. Дисс. биологических наук. (Mechanisms of sensorimotor coordination of movements and postures of a person. PhD diss. of biological sciences.) Санкт-Петербург, изд. ИФРАН. 319 с.]

[40] Bobrova, E. V., Levik, J. S., Bogaceva, I. N. (2009). Kolebanija verhnego i nizhnego zvenjev tela v sagittalnoj ploskosti pri podderzhanii vertikalnoj pozy: Prostranstvenno-vremennyje vzaimootnoshenija. Biofizika, 54 (5), p.935-940. [original: Боброва, Е. В., Левик, Ю. С., Богачева, И. Н. Колебания верхнего и нижнего звеньев тела в сагиттальной плоскости при поддержании вертикальной позы: Пространственно-временные взаимоотношения. (Oscillations of the upper and lower parts of the body in the sagittal plane while maintaining a vertical posture: Spatio-temporal relationships.) Биофизика, 54 (5), с.935-940.]

[41] Bobrova, E. V., Lyakhovetskii, V. A. (2007). Motor memory: Movement- and position-specific sequence representations. Proceedings of European Cognitive Science Conference. Greece, Delphi, p.901.

[42] Bobrova, E. V., Lyakhovetskii, V. A., Bogaceva, I. N. (2015). Obucenie i zaucivanie zapomnennyh posledovatelnostej dvizhenij pravoj i levoj ruki. Zhurnal vysshej nervnoj dejatelnosci, 65 (2), p.212-221. [original: Боброва, Е. В., Ляховецкий, В. А., Богачева, И. Н. Обучение и заучивание запомненных последовательностей движений правой и левой руки. (Learning and completed learning of memorized sequences of movements of the right and left hand.) Журнал высшей нервной деятельности, 65 (2), с.212-221.]

[43] Bobrova, E. V., Lyakhovetskii, V. A., Borschevskaja, E. R. (2009). Ispolzovanie informacii o pravilah pri zapominanii posledovatelnostej dvizhenij levoj i pravoj ruki. Piatyj mezhdunarodnyj mezhdisciplinarnyj kongress 'Neironauka dla mediciny i psihologii', Sudak, p.54-55. [original: Боброва, Е. В., Ляховецкий, В. А., Борщевская, Е. Р. Использование информации о правилах при запоминании последовательности движений левой и правой руки. (Using information about the rules when memorizing the sequence of movements of the left and right hand.) Пятый международный междисциплинарный конгресс 'Нейронаука для медицины и психологии'. Судак, с. 54-55.]

[44] Bobrova, E. V., Lyakhovetskii, V. A., Borschevskaja, E. R. (2010). Rol pravoj ruki v zapominanii prostranstvennoj uporiadocennosti celej pri vosproizvedenii posledovatelnostej dvizhenij. Zhurnal vysshej nervnoj dejatelnosci, 60 (2), p.162-165. [original: Боброва, Е. В., Ляховецкий, В. А., Борщевская, Е. Р. Роль правой руки в запоминании пространственной упорядоченности целей при воспроизведении последовательности движений. (The role of the right hand in remembering the spatial ordering of goals when reproducing a sequence of тоvетеnts.) Журнал высшей нервной деятельности, 60 (2), p.162-165.]

[45] Bobrova, E. V., Lyakhovetskii, V. A., Borschevskaja, E. R. (2011). Rol predystorii v vosproizvedenii posledovatelnostej dvizhenij pravoj i levoj ruki: Kodirovanie polozhenij, dvizhenij, struktury elementov posledovatelnosti. Zhurnal vysshej nervnoj dejatelnosci, 61 (5), p.565-572. [original: Боброва, Е. В., Ляховецкий, В. А., Борщевская, Е. Р. Роль предыстории в воспроизведении последовательностей движений правой или левой руки: Кодирование положений, движений, структуры элементов последовательности. (The role of pre-history in the reproduction of sequences of movements of the right or left hand: Encoding of the positions, movements, structure of the elements of the sequence.) Журнал высшей нервной деятельности, 61 (5), p.565-572.]

[46] Bobrova, E. V., Lyakhovetskii, V. A., Skopin, G. N. (2012). Obucenie vosproizvedeniju sluchajnyh posledovatelnostej dvizhenij pravoj i levoj ruki: Kodirovanie polozhenij i dvizhenij. Zhurnal vysshej nervnoj dejatelnosci, 62 (4), p.422-430. [original: Боброва, Е. В., Ляховецкий, В. А., Скопин, Г. Н. Обучение воспроизведению случайных последовательностей движений правой и левой руки: Кодирование положений и движений. (Learning of reproduction of random sequences of movements of the right and left hand: Coding of positions and movements.) Журнал высшей нервной деятельности, 62 (4), p.422-430.]

[47] Bock, O., Arnold, K. (1993). Error accumulation and error correction in sequential pointing movements. Experimental brain research, July, 95 (1), p.111-117. 
[48] Bock, O., Eckmiller, R. (1986). Goal-directed arm movements in absence of visual guidance: Evidence for amplitude rather than position control. Experimental brain research, May, 62 (3), p.451-458.

[49] Bolshoj psihologiceskij slovar' / rabocaja pamiat' / (2003). ed. B. G. Mescheriakov, V. P. Zinchenko. ed. Moscow, AST Praim-EVROZNAK, 672 p. [original: Большой психологический словарь / Рабочая память / (Big psychological dictionary / working memory /.) ред. Б. Г. Мещеряков, В. П. Зинченко. Москва, изд. АСТ Прайм-ЕВРОЗНАК, 2003. 672 с.]

[50] Bonnel, A. M., Faita, F., Peretz, I., Besson, M. (2001). Divided attention between lyrics and tunes of operatic songs: Evidence for independent processing. Perception and psychophysics, October, 63 (7), p.1201-1213.

[51] Bradshaw, J. L. (2001). Asymmetries in preparation for action (Research news). Trends in cognitive sciences, May, 5 (5), p.184-185.

[52] Brashers-Krug, T., Shadmehr, R., Bizzi, E. (1996). Consolidation in human motor memory. Nature, July, 382, p.252-255.

[53] Bregman, A. S. (1990). Auditory scene analysis: The perceptual organization of sound. ed. Cambridge, MIT Press. $770 \mathrm{p}$.

[54] Broadbent, D. E., Gregory, M. (1963). Division of attention and the decision theory of signal detection. Proceedings of the Royal Society of London. Series B, Biological sciences, September, 158, p.222-231.

[55] Brown, R. M., Robertson, E. M., (2007). Off-line processing: Reciprocal interactions between declarative and procedural memories. Journal of neuroscience, September, 27 (39), p.10468-10475.

[56] Brushlinskij, A. V. (1999). Subjektno-dejatelnostnaja koncepcia i teoria funkcionalnyh sistem. Woprosy psihologii, 5, p.110-121. [original: Брушлинский, А. В. Субъектно-деятельностная концепция и теория функциональных систем. (Subjective activity concept and theory of functional systems.) Вопросы психологии, 5, с.110-121.]

[57] Burgess, P. W., Dumontheil, I., Gilbert, S. J., Okuda, J., Schölvinck, M. L., Simons, J. S. (2008). On the role of rostral prefrontal cortex (area 10) in prospective memory. In: M. Kliegel, M. A., McDaniel, G. O. Einstein (eds.), Prospective memory: Cognitive, neuroscience, developmental, and applied perspectives. Chapter 11. ed. New York, Taylor and Francis Group, Lawrence Erlbaum Associates. 488 p., p.235-260.

[58] Burgess, P. W., Gonen-Yaacovi, G., Volle, E. (2011). Functional neuroimaging studies of prospective memory: What have we learnt so far? Neuropsychologia, 49 (8), p.2246-2257.

[59] Burgess, P. W., Quayle, A., Frith, C. D. (2001). Brain regions involved in prospective memory as determined by positron emission tomography. Neuropsychologia, 39 (6), p.545-555.

[60] Burgess, P. W, Scott, S. K, Frith, C. D. (2003). The role of the rostral frontal cortex (area 10) in prospective memory: A lateral versus medial dissociation. Neuropsychologia, 41 (8), p.906-918.

[61] Burgess, P. W., Veitch, E., de Lacy Costello, A., Shallice, T. (2000). The cognitive and neuroanatomical correlates of multitasking. Neuropsychologia, 38 (6), p.848-863.

[62] Byo, J. L. (1997). The effects of texture and number of parts on the ability of music majors to detect performance errors. Journal of research in music education, April, 45 (1), p.51-66.

[63] Caminiti, R., Johnson, P. B., Galli, C., Ferraina, S., Burnod, Y. (1991). Making arm movements within different parts of space: The premotor and motor cortical representation of a coordinate system for reaching to visual targets. Journal of neuroscience, May, 11 (5), p.1182-1197.

[64] Chein, J. M., Schneider, W., (2005). Neuroimaging studies of practice-related change: fMRI and meta-analytic evidence of a domain-general control network for learning. Brain research. Cognitive brain research, December, 25 (3), p.607-623.

[65] Chen, R., Gerloff, C., Hallett, M., Cohen, L. G. (1997). Involvement of the ipsilateral motor cortex in finger movements of different complexities. Annals of neurology, February, 41 (2), p.247-254.

[66] Chuprikova, N. I. (2008). Kak vyvesti psihologiu vnimanija iz teoreticeskogo tupika. Voprosy psihologii, 5, p.13-30. [original: Чуприкова, Н. И. Как вывести психологию внимания из теоретического тупика. (How to get the psychology of attention out of a theoretical impasse.) Вопросы психологии, 5, с.13-30.]

[67] Ceremoshkina, L. V. (2002). Psihologia pamiati. ed. Moscow, Academia. 368 p. [original: Черемошкина, Л. В. Психология памяти. (Psychology of тетоry.) Москва, изд. Академия. 368 с.]

[68] Chermak, G. D., Musiek, F. E. (1997). Central auditory processing disorders: New perspectives. ed. San Diego, CA, Singular Pub Group. 374 p.

[69] Chun, M. M., Phelps, E. A. (1999). Memory deficits for implicit contextual information in amnesic subjects with hippocampal damage. Nature neuroscience, September, 2 (9), p.844-847.

[70] Ciccola, A. (2008). Neural correlates of prospective memory. PhD diss. ed. Italy, Univerista degli Studi di Padova.

[71] Cockburn, J. (2006). The neurology and neuropsychology of time-based prospective memory. In: J. Glicksohn, M. S. Myslobodsky. (ed.), Timing the future. The case for a time-based prospective memory, ed. Singapore, World Scientific Publishing Company, p.239-262. 
[72] Creem-Regehr, S. H. (2009). Sensory-motor and cognitive functions of the human posterior parietal cortex involved in manual actions. Neurobiology of learning and memory, 91 (2), p.166-171.

[73] Colby, C. L. (1998). Action-oriented spatial reference frames in cortex. Neuron, January, 20 (1), p.15-24.

[74] Corballis, M. C. (1998). Cerebral asymmetry: Motoring on. Trends in cognitive sciences, April, 2 (4), p.152-157.

[75] Cleeremans, A., Jimenez, L. (2002). Implicit learning and consciousness: A graded dynamic perspective. In: R. M. French, A. Cleeremans (ed.), Implicit learning and consciousness. ed. Hove, U. K. Psychology Press, p.1-40.

[76] Clower, D. M., Dum, R. P., Strick, P. L. (2005). Basal ganglia and cerebellar inputs to 'AIP'. Cerebral cortex, July, 15 (7), p.913-920.

[77] Cohen, D. A., Pascual-Leone, A., Press, D. Z., Robertson, E. M. (2005). Off-line learning of motor skill memory: A double dissociation of goal and movement. Proceedings of the National Academy of Sciences of the United States of America, December, 102 (50), p.18237-18241.

[78] Cohen, D. A., Robertson, E. M. (2007). Motor sequence consolidation: Constrained by critical time windows or competing components. Experimental brain research, March, 177 (4), p.440-446.

[79] Compton, R. J. (2003). The interface between emotion and attention: A review of evidence from psychology and neuroscience. Behavioral and cognitive neuroscience reviews, June, 2(2), p.115-129.

[80] Cousins, J. N., El-Deredy, W., Parkes, L. M., Hennies, N., Lewis, P. A. (2014). Cued memory reactivation during slow-wave sleep promotes explicit knowledge of a motor sequence. Journal of neuroscience, November, 34 (38), p.15870-15876.

[81] Cousins, J. N., El-Deredy, W., Parkes, L. M., Hennies, N., Lewis, P. A. (2016). Cued reactivation of motor learning during sleep leads to overnight changes in functional brain activity and connectivity. PLoS biology, May, 14 (5), e1002451, 21p.

[82] Cowan, N. (1998). Attention and memory: An integrated framework. Oxford psychology series, No. 26. ed. New York, Oxford University Press. 344 p.

[83] Cowan, N. A. (1998). Visual and auditory working memory capacity. Trends in cognitive sciences, March, 2 (3), p.77.

[84] Cowan, N. A. (1999). An embedded - processes model of working memory. In: A. Miyake, P. Shah (eds.), Models of working memory: Mechanisms of active maintenance and executive control. ed. Cambridge, Cambridge University Press, p.62-101.

[85] Cowan, N. A. (2001), The magical number 4 in short - term memory: A reconsideration of mental storage capacity. Behavioral and brain sciences, February, 24 (1), p.87-185.

[86] Cowan, N. A. (2005). Working memory capacity. Essays in cognitive psychology. ed. Psychology Press. 260 p.

[87] Cowan, N. A. (2008). What are the differences between long - term, short - term, and working memory? Progress in brain research, 169, p.323-338. 18p.

[88] Cowan, N. A., Morey, C. C., AuBuchon, A. M., Zwilling, C. E., Gilchrist, A. L. (2010). Seven - year - olds allocate attention like adults unless working memory is overloaded. Developmental science, January, 13 (1), p.120-133.

[89] Cowan, N. A. (1999). An embedded - processes model of working memory. In: A. Miyake, P. Shah (eds.), Models of working memory: Mechanisms of active maintenance and executive control. ed. Cambridge, Cambridge University Press, p.62-101.

[90] Creem-Regehr, S. H. (2009). Sensory-motor and cognitive functions of the human posterior parietal cortex involved in manual actions. Neurobiology of learning and memory, February, 91 (2), p.166-171.

[91] Crystal, J. D. (2012). Animal models of human cognition. In: J. Vonk, T. Shackelford (eds.), Oxford handbook of comparative evolutionary psychology. ed. Oxford, Oxford University Press, p.261-270.

[92] Crystal, J. D., Glanzman, D. L. (2013). A biological perspective on memory. Current biology, September, 23 (17), p.728-731.

[93] Cuttler, C., Graf, P. (2008). Sub-clinical checking compulsions are related to impaired prospective memory independently of depression, anxiety and distractibility. Journal of anxiety disorders, May, 22 (4), p.642-654.

[94] Cypin, G. M. (2017). Obucenie igre na fortepiano. ed. Moscow, Jurajt. 217 p. [original: Цыпин, Г. М. Обучение игре на фортепиано.(Educating of playing the forte-piano.) Мосkва, изд. Юрайт. 217 с.]

[95] Damasio, A. R., Grabowski, T. J., Bechara, A., Damasio, H., Ponto, L. L., Parvizi, J., Hichwa, R. D. (2000). Subcortical and cortical brain activity during the feeling of self-generated emotions. Nature neuroscience, October, 3 (10), p.1049-1056.

[96] Danilova, N. N., Krylova, A. L. (2005). Fiziologia vysshej nervnoj dejatelnosci. ed. Rostow na Donu, FENIKS, 478 р. [original: Данилова, Н. Н., Крылова, А. Л. Физиология высшей нервной деятельности. (Physiology of higher nervous activity.) Ростов на Дону, изд. ФЕНИКС. 478 с.] 
[97] De Koninck, J., Lorrain, D., Christ, G., Proulx, G., Coulombe, D. (1989). Intensive language learning and increases in rapid eye movement sleep: Evidence of a performance factor. International journal of psychophysiology, September, 8 (1), p.43-47.

[98] De Lucia, M., Constantinescu, I., Sterpenich, V., Pourtois, G., Seeck, M., Schwartz, S. (2011). Decoding sequence learning from single-trial intracranial EEG in humans. PLoS One, December, 6 (12), e28630, 11 p.

[99] Debarnot, U., Abichou, K., Kalenzaga, S., Sperduti, M., Piolino, P. (2015). Variable motor imagery training induces sleep memory consolidation and transfer improvements. Neurobiology of learning and memory, March, 119 , p.85-92.

[100] Debarnot, U., Castellani, E., Guillot, A. (2012). Selective delayed gains following motor imagery of complex movements. Archives italiennes de biologie, December, 150 (4), p.238-250.

[101] Debarnot, U., Creveaux, T., Collet, C., Doyon, J., Guillot, A. (2009). Sleep contribution to motor memory consolidation: A motor imagery study. Sleep, December, 32 (12), p.1559-1565.

[102] Demorest, S. M., Serlin, R. C. (1997). The integration of pitch and rhythm in musical judgment: Testing age-related trends in novice listeners. Journal of research in music education, spring, March, 45 (1), p.67-79.

[103] Diamond, A. (2013). Executive functions. Annual review of psychology, 64, p.135-168.

[104] Diedrichsen, J., Balsters, J. H., Flavell, J., Cussans, E., Ramnani, N. (2009). A probabilistic MR atlas of the human cerebellum. Neuroimage, May, 46 (1), p.39-46.

[105] Diekelmann, S., Born, J., Rasch, B. (2016). Increasing explicit sequence knowledge by odor cueing during sleep in men but not women. Frontiers in behavioral neuroscience, April, 10, art.74, $11 \mathrm{p}$.

[106] Diekelmann, S., Wilhelm, I., Born, J. (2009). The whats and whens of sleep-dependent memory consolidation. Sleep medicine reviews, October, 13 (5), p.309-321.

[107] Diekelmann, S., Wilhelm, I., Wagner, U., Born, J. (2013). Sleep to implement an intention. Sleep, January, 36 (1), p.149-153.

[108] Dismukes, R. K. (2008). Prospective memory in aviation and everyday settings. In: M. Kliegel, M. A., McDaniel, G. O. Einstein (eds.), Prospective memory: Cognitive, neuroscience, developmental, and applied perspectives. Chapter 19. ed. New York, Taylor and Francis Group, Lawrence Erlbaum Associates. 488 p., p.411-432.

[109] Dismukes, R. K. (2012). Prospective memory in workplace and everyday situations. Current directions in psychological science, August, 21 (4), p.215-220.

[110] Dobbs, A. R., Rule, B. G. (1987). Prospective memory and self-reports of memory abilities in older adults. Canadian journal of psychology, June, 41 (2), p.209-222.

[111] Dolan, R. J. (2002). Emotion, cognition, and behavior. Science, November, 298 (5596), p.1191-1194.

[112] Dominey, P. F., Lelekov, T., Ventre-Dominey, J., Jeannerod, M. (1998). Dissociable processes for learning the surface structure and abstract structure of sensorimotor sequences. Journal of cognitive neuroscience, November, 10 (6), p.734-751.

[113] Doyon, J., Bellec, P., Amsel, R., Penhune, V., Monchi, O., Carrier, J., Lehericy, S., Benali, H. (2009). Contributions of the basal ganglia and functionally related brain structures to motor learning. Behavioural brain research, April, 199 (1), p.61-75.

[114] Doyon, J., Benali, H. (2005). Reorganization and plasticity in the adult human brain during learning of motor skills. Current opinion in neurobiology, April, 15 (2), p.161-167.

[115] Dudai, Y. (2012). The restless engram: Consolidations never end. Annual review of neuroscience, 35, p. 227-247.

[116] Dushkov, B. A., Smirnov, B. A., Koroljov, A. V. (2005). Psihologia truda, professionalnoj, informacionnoj $i$ organizacionnoj dejatelnosti. Slowar'. / operatiwnaja pamiat /. ed. Moscow. Akademiceskij projekt. Gaudeamus. p.360-362. [original: Душков, Б. А., Смирнов, Б. А., Королёв, А. В. Психология труда, профессиональной, информационной и организационной деятельности. Словарь. / Оперативная память /. (Psychology of labor, professional, informational and organizational activities. Dictionary. / working memory /.) Москва, изд. Академический проект. Gaudeamus. с.360-362.]

[117] Dymnikowa, M. (2018). Diagnostika muzykalnoj pamiati. ed. Saint-Petersburg, LEMA. 184 p. [original: Дымникова, М. Диагностика музыкальной памяти. (Mиsic тетоry diagnosis.) Санкт-Петербург, изд. ЛЕМА. 184 с.]

[118] Ebbinghaus, H. (1885). Memory: A contribution to experimental psychology. ed. New York, Dover, reprint Martino Fine Books, September 2011, 134 p.

[119] Einstein, G. O., McDaniel, M. A. (1990). Normal aging and prospective memory. Journal of experimental psychology: Learning, memory, and cognition. July, 16 (4), p.717-726. 
[120] Einstein, G. O., McDaniel, M. A., Manzi, M., Cochran, B., Baker, M. (2000). Prospective memory and aging: Forgetting intentions over short delays. Psychology and Aging, December, 15 (4), p.671-683.

[121] Einstein, G., McDaniel, M., Thomas, R., Mayfield, S., Shank, H., Morrisette, N., Breneiser, J. (2005). Multiple processes in prospective memory retrieval: Factors determining monitoring versus spontaneous retrieval. Journal of experimental psychology. General. August, 134 (3), p.327-342.

[122] Ellenbogen, J. M., Hu, P. T., Payne, J. D., Titone, D., Walker, M. P. (2007). Human relational memory requires time and sleep. Proceedings of the National Academy of Sciences of the United States of America, May, 104 (18), p.7723-7728.

[123] Ellis, J. A., Freeman, J. E. (2008). Ten years on: Realizing delayed intentions. In: M. Kliegel, M. A., McDaniel, G. O. Einstein (eds.), Prospective memory: Cognitive, neuroscience, developmental, and applied perspectives. Chapter 1. ed. New York, Taylor and Francis Group, Lawrence Erlbaum Associates. 488 p., p.1-27.

[124] Ergorul, C., Eichenbaum, H. (2006). Essential role of the hippocampal formation in rapid learning of higher-order sequential associations. Journal of neuroscience, April, 26 (15), p.4111-4117.

[125] Ericsson, K. A., Kintsch, W. (1995). Long-term working memory. Psychological Review, April, 102 (2), p.211-245.

[126] Farber, D. A., Semenova, L. K., Alferova, V. V. (1990). Strukturno-funkcionalnoe sozrevanie razvivajusiegosia mozga. ed. Leningrad, Nauka, 198 р. [original: Фарбер, Д. А, Семенова, Л. К, Алферова, В. В. Структурнофункииональное созревание развивающегося мозга (Structural-functional maturation of the developing brain.) Ленинград, изд. Наука, 198 с.]

[127] Fejnberg, S. E. (2019). Pianizm kak iskusstvo. ed. Saint-Petersburg, Planeta muzyki, 560 p. [original: Фейнберг, С. Е. Пианизм как искусство. (Pianism as an art.) Санкт-Петербург, изд. Планета музыки. 560 с.]

[128] Feldman, A. G. (1966). Functional tuning of the nervous system with control of movement or maintenance of a steady posture. II. Controllable parameters of the muscles. Biophysics, 11, p.565-578.

[129] Fernández-Seara, M. A., Aznárez-Sanado, M., Mengual, E., Loayza, F. R., Pastor, M. A. (2009). Continuous performance of a novel motor sequence leads to highly correlated striatal and hippocampal perfusion increases. Neuroimage, October, 47 (4), p.1797-1808.

[130] Fischer, S., Born, J. (2009). Anticipated reward enhances offline learning during sleep. Journal of experimental psychology: Learning, memory and cognition, November, 35 (6), p.1586-1593.

[131] Fischer, S., Drosopoulos, S., Tsen, J., Born, J. (2006). Implicit learning - explicit knowing: A role for sleep in memory system interaction. Journal of cognitive neuroscience, March, 18 (3), p.311-319.

[132] Fischer, S., Hallschmid, M., Elsner, A. L., Born, J. (2002). Sleep forms memory for finger skills. Proceedings of the National Academy of Sciences of the United States of America, September, 99 (18), p.11987-11991.

[133] Fischer, S., Nitschke, M. F., Melchert, U. H., Erdmann, C., Born, J. (2005). Motor memory consolidation in sleep shapes more effective neuronal representations. Journal of neuroscience, December, 25 (49), p.11248-11255.

[134] Fletcher, P. C., Zafiris, O., Frith, C. D., Honey, R. A., Corlett, P. R., Zilles, K., Fink, G. R. (2005). On the benefits of not trying: Brain activity and connectivity reflecting the interactions of explicit and implicit sequence learning. Cerebral cortex, July, 15 (7), p.1002-1015.

[135] Fogel, S. M., Smith, C. T. (2006). Learning-dependent changes in sleep spindles and Stage 2 sleep. Journal of sleep research, September, 15 (3), p.250-255.

[136] Francès, R. (1988). The perception of music. ed. Lawrence Erlbaum Associates. 390 p.

[137] Frankland, P. W., Bontempi, B. (2005). The organization of recent and remote memories. Nature reviews. Neuroscience. February, 6 (2), p.119-130.

[138] Frey, U., Morris, R. G. (1997). Synaptic tagging and long-term potentiation. Nature, February, 385 (6616), p.533-536.

[139] Gais, S., Plihal, W., Wagner, U., Born, J. (2000). Early sleep triggers memory for early visual discrimination skills. Nature neuroscience, December, 3, p.1335-1339.

[140] Gallistel, C. R., Matzel, L. D. (2013). The neuroscience of learning: Beyond the Hebbian synapse. Annual review of psychology, January, vol. 64 (1), p.169-200.

[141] Gardner, H. (1983). Frames of mind: The theory of multiple intelligences. ed. New York, Basic Books. $440 \mathrm{p}$.

[142] Gardner, H. (1999). Intelligence reframed: Multiple intelligences for the $21^{\text {st }}$ century. ed. New York, Basic Books. 292 p.

[143] Gardner, H. (1995). Reflections on multiple intelligences: Myths and messages. Phi delta kappan international, November, 77 (3), p.200-203, 206-209. 
[144] Gardner, H. (1998). Are there additional intelligences? The case for naturalist, spiritual, and existential intelligences. In J. Kane (ed.), Education, information, and transformation. ed. Englewood Cliffs, NJ, Prentice Hall, p.111-131.

[145] Gardner, H. (2000). A Case Against Spiritual Intelligence. International journal for the psychology of religion, January, 10 (1), p.27-34.

[146] Gardner, H., Kornhaber, M. L., Wake, W. K. (1996). Intelligence: Multiple Perspectives. ed. Harcourt Brace College Publishers. 351 p.

[147] Gathercole, S. E. The development of memory. (2003). Journal of child psychology and psychiatry, January, 39 (1), p.3-27.

[148] Gathercole, S. E., Pickering, S. J., Ambridge, B., Wearing, H. (2004). The structure of working memory from 4 to 15 years of age. Developmental psychology, March, 40 (2), p.177-190.

[149] Genzel, L., Dresler, M., Wehrle, R., Grözinger, M., Steiger, A. (2009). Slow wave sleep and REM sleep awakenings do not affect sleep dependent memory consolidation. Sleep, March, 32 (3), p.302-310.

[150] Genzel, L., Quack, A., Jäger, E., Konrad, B., Steiger, A., Dresler, M. (2012). Complex motor sequence skills profit from sleep. Neuropsychobiology, October, 66 (4), p.237-243.

[151] Georgopoulos, A. P., Kalaska, J. F., Caminiti, R., Massey, J. T. (1982). Journal of neuroscience, November, 2 (11), p.1527-1537.

[152] Georgopoulos, A. P., Kettner, R. E., Schwartz, A. B. (1988). Primate motor cortex and free arm movements to visual targets in three-dimensional space. II. Coding of the direction of movement by a neuronal population. Journal of neuroscience, August, 8 (8), p.2928-2937.

[153] Ghahramani, Z., Wolpert, D. M. (1997). Modular decomposition in visuomotor learning. Nature, March, 386 (6623), p.392-395.

[154] Gheysen, F., Van Opstal, F., Roggeman, C., Van Waelvelde, H., Fias, W. (2010). Hippocampal contribution to early and later stages of implicit motor sequence learning. Experimental brain research, May, 202 (4), p.795-807.

[155] Ghilardi, M. F., Moisello, C., Silvestri, G., Ghez, C., Krakauer, J. W. (2009). Learning of a sequential motor skill comprises explicit and implicit components that consolidate differently. Journal of neurophysiology, May, 101 (5), p.2218-2229.

[156] Glezer, V. D. (1998). The role of spatial frequency analysis and primitives in abstract and full description of image in left and right hemispheres. In: C. Taddei-Feretti, C. Musio (eds.), Downward processes in the perception representation mechanisms. ed. Singapore, World Scientific Publishing Company. 580 p., p.99-107.

[157] Goldman-Rakic, P. S. (1987). Circuitry of the frontal association cortex and its relevance to dementia. Archives of gerontology and geriatrics, September, 6 (3), p.299-309.

[158] Gollwitzer, P. M. (1999). Implementation intentions: Strong effects of simple plans. American psychologist, July, 54 (7), p.493-503.

[159] Goschke, T., Kuhl, J. (1993). The representation of intentions: Persisting activation in memory. Journal of experimental psychology: Learning, memory, and cognition. September, 19 (5), p.1211-1226.

[160] Graf, P., Grondin, S. (2006). Time perception and time-based prospective memory. In: J. Glicksohn, M. S. Myslobodsky (eds.), Timing the future. The case for a time-based prospective memory. ed. Singapore, World Scientific Publishing Company. 324 p., p.1-24.

[161] Grafton, S. T. (2008). Malleable templates: Reshaping our crystallized skills to create new outcomes. Nature neuroscience, March, 11 (3), p.248-249.

[162] Grafton, S. T., Hazeltine, E., Ivry, R. B. (1998). Abstract and effector-specific representations of motor sequences identified with PET. Journal of neuroscience, November, 18 (22), p.9420-9428.

[163] Grafton, S. T., Hazeltine, E., Ivry, R. B. (2002). Motor sequence learning with the nondominant left hand. A PET functional imaging study. Experimental brain research, October, 146 (3), p.369-378.

[164] Graziano, M. S., Taylor, C. S., Moore, T., Cooke, D. F. (2002). The cortical control of movement revisited. Neuron, October, 36 (3), p.349-362.

[165] Gromova, E. A. (1976). Ob emocionalnoj pamiati i biogennych processah. In: E. A. Gromova. Strukturno emonionalnye osnowy mehaniceskoj pamiati. ed. Moscow, Nauka. 98 p. [original: Громова, Е. А. Об эмоциональной памяти и биогенных процессах. (About emotional memory and biogenic processes.) / Е. А. Громова. Структурно-эмочиональные основы механической памяти. (Structurally-emotional fundamentals of mechanical memory.) Москва, изд. Наука. 98 с.]

[166] Guida, A., Gobert, F., Tardieu, H., Nocolas, S. (2012). How chunks, long - term working memory and templates offer a cognitive explanation for neuroimaging data on expertise acquisition: A two - stage framework. Brain and cognition, August, 79 (3), p.221-244. 
[167] Guida, A., Tardieu, H. (2005). Is personalization a way to operationalize long - term working memory? Current psychology letters. Behavior, brain and cognition. 15 (1), p.1-15.

[168] Guida, A., Tardieu, H., Nicolas, S. (2009). The personalization method applied to a working memory task: Evidence of long - term working memory effects. European journal of cognitive psychology, January, 21 (6), p.862-896.

[169] Haaland, K. Y. (2006). Left hemisphere dominance for movement. Clinical neuropsychologist, December, 20 (4), p.609-622.

[170] Haaland, K. Y., Elsinger, C. L., Mayer, A. R., Durgerian, S., Rao, S. M. (2004). Motor sequence complexity and performing hand produce differential patterns of hemispheric lateralization. Journal of cognitive neuroscience, May, 16 (4), p.621-636.

[171] Haaland, K. Y., Harrington, D. L. (1996). Hemispheric asymmetry of movement. Current opinion in neurobiology, December, 6 (6), p.796-800.

[172] Haaland, K. Y., Harrington, D. L., Knight, R. T. (2000). Neural representations of skilled movement. Brain, November, 123, pt.11, p.2306-2313.

[173] Haaland, K. Y., Prestopnik, J. L, Knight, R. T., Lee, R. R. (2004). Hemispheric asymmetries for kinematic and positional aspects of reaching. Brain, May, 127, pt.5, p.1145-1158.

[174] Hall, J. E. (2016). Guyton and hall textbook of medical physiology. ed. Elsevier. Inc. 1168 p.

[175] Hallgató, E., Győri-Dani, D., Pekár, J., Janacsek, K., Nemeth, D. (2013). The differential consolidation of perceptual and motor learning in skill acquisition. Cortex, April, 49 (4), p.1073-1081.

[176] Halsband, U., Lange, R. K. (2006). Motor learning in man: A review of functional and clinical studies. Journal of physiology, June, 99 (4-6), p.414-424.

[177] Hamaoui, K., Deutsch, D. (2010). The perceptual grouping of musical sequences: Pitch and timing as competing cues. In: S. M. Demorest, S. J. Morrison, P. S. Campbell (eds.), Proceedings of the $11^{\text {th }}$ International conference on music perception and cognition. July, p.81-87.

[178] Harrington, D. L., Haaland, K. Y. (1991). Hemispheric specialization for motor sequencing: Abnormalities in levels of programming. Neuropsychologia, 29 (2), p.147-163.

[179] Heffernan, T., Clark, R., Bartholomew, J., Ling, J., Stephens, R. (2010). Does binge drinking in teenagers affect their everyday prospective memory? Drug and alcohol dependence, June, 109 (1-3), p.73-78.

[180] Heffernan, T. M, O'Neill, T. S. (2013). Exposure to second-hand smoke damages everyday prospective memory. Addiction, February, 108 (2), p.420-426.

[181] Heffernan, T., O’Neill, T. S., Moss, M. (2010). Smoking and everyday prospective memory: A comparison of self-report and objective methodologies. Drug and alcohol dependence, December, 112 (3), p.234-238.

[182] Heffernan, T. M., O’Neill, T. S., Moss, M. (2012). Smoking-related prospective memory deficits in a real-world task. Drug and alcohol dependence, January, 120 (1-3), p.1-6.

[183] Higgins, S. (1991). Motor skill acquisition. Physical therapy, February, 71 (2), p.123-139.

[184] Hikosaka, O., Nakahara, H., Rand, M. K., Sakai, K., Lu, X., Nakamura, K., Miyachi, S., Doya, K. (1999). Parallel neural networks for learning sequential procedures. Trends in neurosciences, October, 22 (10), p.464-471.

[185] Hikosaka, O., Nakamura, K., Sakai, K., Nakahara, H. (2002). Central mechanisms of motor skill learning. Current opinion in neurobiology, April, 12 (2), p.217-222.

[186] Hikosaka, O., Sakai, K., Miyauchi, S., Takino., R., Sasaki, Y., Pütz, B. (1996). Activation of human presupplementary motor area in learning of sequential procedures: A functional MRI study. Journal of neurophysiology, July, 76 (1), p.617-621.

[187] Hilgard, E. R. (1987). Psychology in America: A historical survey. ed. San Diego, Harcourt Brace Jovanovich. $1009 \mathrm{p}$.

[188] Homskaja, E. D. (1979). Neirofiziologiceskie mehanizmy vnimanija. ed. Moscow, MGU. 301 p. [original: Хомская, Е. Д. Нейрофизиологические механизмы внимания.(Neurophysiological mechanisms of attention.) Москва, изд. МГУ, 301 с.]

[189] Homskaja, E. D. (2004). Ob asimmetrii blokov mozga. In: E. D. Homskaja. Hrestomatija po neiropsihologii. ed. Moscow, Institut obsiegumanitarnyh issledovanij MPSI. 896 p., p.199-211. [original: Хомская, Е. Д. Об асимметрии блоков мозга. (On the asymmetry of brain blocks.) / Е. Д. Хомская. Хрестоматия nо нейропсихологии. (Anthology on neuropsychology.) Москва, изд. Институт общегуманитарных исследований МПСИ. 896 с., с.199-211.]

[190] Honda, M., Deiber, M. P., Ibanez, V., Pascual-Leone, A., Zhuang, P., Hallett, M. (1998). Dynamic cortical involvement in implicit and explicit motor sequence learning. A PET study. Brain, November, 121, pt.11, p.2159-2173. 
[191] Hu, P., Stylos-Allan, M., Walker, M. P. (2006). Sleep facilitates consolidation of emotionally arousing declarative memory. Psychological science, October, 17 (10), p.891-898.

[192] Huber, R., Ghilardi, M. F., Massimini, M., Tononi, G. (2004). Local sleep and learning. Nature, July, 430 (6995), p.78-81.

[193] Iacoboni, M. (2005). Neural mechanisms of imitation. Current opinion in neurobiology, December, 15 (6), p.632-637.

[194] Ioffe, M. E. (1975). Kortiko-spinalnyje mechanizmy instrumentalnych dwigatelnyh reakcij. ed. Moscow, Nauka, 203 р. [original: Иоффе, М. Е. Кортико-спинальные механизмы инструментальных двигательных реакций. (Cortico-spinal mechanisms of instrumental motor reactions.) Москва, изд. Наука. 203 с.]

[195] Ioffe, M. E. (1991). Mechanizmy dvigatelnogo obucenija. ed. Moscow, Nauka, 135 p. [original: Иoффe, M. E. Механизмы двигательного обучения. (Mechanisms of motor learning.) Москва, изд. Наука. 135 с.]

[196] Ioffe, M. E. (2003). Mozgovye mechanizmy formirovanija novyh dvizhenij pri obucenii: Evolucija klassiceskih predstawlenij. Zhurnal vysshej nervnoj dejatelnosci, 53 (1), p.5-21. [original: Иоффе, М. Е. Мозговые механизмы формирования новых движений при обучении: Эволюция классических представлений. (Brain mechanisms of the formation of new movements in learning: Evolution of classical representations.) Журнал высшей нервной деятельности, 53 (1), с.5-21.]

[197] Iriki, A., Pavlides, C., Keller, A., Asanuma, H. (1989). Long-term potentiation in the motor cortex. Science, September, 245 (4924), p.1385-1387.

[198] Ito, M. (2005). Bases and implications of learning in the cerebellum-adaptive control and internal model mechanism. Progress in brain research, 148, p.95-109.

[199] Jager, G., Postma, A. (2003). On the hemispheric specialization for categorical and coordinate spatial relations: A review of the current evidence. Neuropsychologia, 41 (4), p.504-515.

[200] Jarrold, C., Bayliss, D. M. (2008). Variation in working memory due to typical and atypical development. In: A. Conway, Ch. Jarrold, M. Kane, A. Miyake, J. Towse (ed.), Variation in working memory. ed. New York, Oxford University Press. 348 p., p.134-161.

[201] Jodzio, K. (2008). Neuropsychologia intencjonalnego działania. Koncepcje funkcji wykonawczych. (Neuropsychology of intentional action. Concepts of executive functions.) ed. Warszawa, SCHOLAR. 390 p.

[202] Johnson, J. A., Zatorre, R. J. (2005). Attention to simultaneous unrelated auditory and visual events: Behavioral and neural correlates. Cerebral cortex, October, 15 (10), p.1609-1620.

[203] Kahneman, D. (1973). Attention and perception. In: D. Kahneman. Attention and effort. ed. Englwood Cliffs, NJ, Prentice Hall. 246 p., p.66-97.

[204] Kalm, K., Davis, M. H., Norris, D. (2013). Individual sequence representations in the medial temporal lobe. Journal of cognitive neuroscience, July, 25 (7), p.1111-1121.

[205] Kandel, E. R., Dudai, Y., Mayford, M. R. (2014). The molecular and systems biology of memory. Cell, March, 157 (1), p.163-186.

[206] Karni, A., Meyer, G., Jezzard, P., Adams, M. M., Turner, R., Ungerleider, L. G. (1995). Functional MRI evidence for adult motor cortex plasticity during motor skill learning. Nature, September, 377 (6545), p.155-158.

[207] Karni, A., Meyer, G., Rey-Hipolito, C., Jezzard, P., Adams, M. M., Turner, R., Ungerleider, L. G. (1998). The acquisition of skilled motor performance: Fast and slow experience driven changes in primary motor cortex. Proceedings of the National Academy of Sciences of the United States of America, February, 95 (3), p.861-868.

[208] Karni, A., Sagi, D. (1993). The time course of learning a visual skill. Nature, September, 365 (6443), p.250-252.

[209] Karni, A., Tanne, D., Rubenstein, B. S., Askenasy, J. J., Sagi, D. (1994). Dependence on REM sleep of overnight improvement of a perceptual skill. Science, July, 265 (5172), p.679-682.

[210] Kawato, M. (1999). Internal models for motor control and trajectory planning. Current opinion in neurobiology, December, 9 (6), p.718-727.

[211] Kawato, M., Kuroda, T., Imamizu, H., Nakano, E., Miyauchi, S., Yoshioka, T. (2003). Internal forward models in the cerebellum: fMRI study on grip force and load force coupling. Progress in brain research, 142, p.171-188.

[212] Keller, A., Arissian, K., Asanuma, H. (1990). Formation of new synapses in the cat motor cortex following lesions of the deep cerebellar nuclei. Experimental brain research, 80 (1), p.23-33.

[213] Kelly, R. M., Strick, P. L. (2003). Cerebellar loops with motor cortex and prefrontal cortex of a non-human primate. Journal of neuroscience, September, 23 (23), p.8432-8444.

[214] Kensinger, E. A., Corkin, S. (2003). Effect of negative emotional content on working memory and long-term memory. Emotion, December, 3 (4), p.378-393.

[215] Keppel, G., Underwood, B. J. (1962). Proactive inhibition in short-term retention of single items. Journal of verbal learning and verbal behavior, October, 1 (3), p.153-161. 
[216] Killgore, W. D. S., Yurgelun-Todd, D. A. (2007). The right - hemisphere and valence hypothesis: Could they both be right (and sometimes left)? Social cognitive and affective neuroscience, September, 2 (3), p.240-250.

[217] Kimura, D., Archibald, Y. (1974). Motor function of the left hemisphere. Brain, June, vol. 97 (2), p.337-350.

[218] King, B. R., Hoedlmoser, K., Hirschauer, F., Dolfen, N., Albouy, G. (2017). Sleeping on the motor engram: The multifaceted nature of sleep-related motor memory consolidation. Neuroscience and behavioral reviews, September, 80, p.1-22.

[219] King, B., Saucier, P., Albouy, G., Fogel, S., Rumpf, J., Klann, J., Buccino, G., Binkofski, F., Classen, J., Karni, A., Doyon, J. (2017). Cerebral activation during initial motor learning forecasts subsequent sleep-facilitated memory consolidation in older adults. Cerebral cortex, February, 27 (2), p.1588-1601.

[220] Kintsch, W., Patel, V. L., Ericsson, K. A. (1999). The role of long - term working memory in text comprehension. Psychologia, December, 42 (4), p.186-198.

[221] Kirnarskaja, D. K. (2004). Muzykalnye sposobnosti. Ed.Moscow, Talanty-XXI viek. 496 p. [original: Кирнарская, Д. К. Музыкальныле способности. (Musical abilities.) изд. Москва, Таланты-ХХІ век, 496 с.]

[222] Klein, R. M. (1997). Attention and visual dominance: A chronometric analysis. Journal of experimental psychology: Human perception and performance, August, 3 (3), p.365-378.

[223] Kleitman, N. (1961). The nature of dreaming. In: G. E. W. Wolstenholme, M. O’Connor. The nature of sleep, ed. London, Churchill. 416 p., p.349-364.

[224] Kleitman, N. (1963). Sleep and Wakefulness. ed. Chicago, University of Chicago Press. 552 p.

[225] Kleitman, N. (1982). Basic rest-activity cycle - 22 years later. Sleep, 5 (4), p.311-317.

[226] Kliegel, M., Jäger, T., Altgassen, M., Shum, D. (2007). Clinical neuropsychology of prospective memory. In: M. Kliegel, M. A., McDaniel, G. O. Einstein (eds.), Prospective memory: Cognitive, neuroscience, developmental, and applied perspectives. Chapter 13. ed. New York, Taylor and Francis Group, Lawrence Erlbaum Associates. 488 p., p.283-308.

[227] Kliegel, M., Eschen, A., Thöne-Otto, A. I. (2004). Planning and realization of complex intentions in traumatic brain injury and normal aging. Brain and cognition, October, 56 (1), p.43-54.

[228] Kliegel, M., Martin, M. (2010). Prospective memory research: Why is it relevant? International Journal of Psychology, August, 38 (4), p.193-194.

[229] Kliegel, M., Ropeter, A., Mackinlay, R. (2006). Complex prospective memory in children with ADHD. Child neuropsychology, December, 12 (6), p.407-419.

[230] Klimesch, W. (2012). Alpha-band oscillations, attention, and controlled access to stored information. Trends in cognitive sciences. December, 16 (12), p.606-617.

[231] Komarova, T. K. (2002). Psihologia vnimanija. ed. Grodno, GrGU. 124 p. [original: Комарова, T. К. Психология внимания. (Psychology of attention.) изд. Гродно, ГрГУ.124 с.]

[232] Kondo, K., Maruishi, M., Ueno, H., Sawada, K., Hashimoto, Y., Ohshita, T., Takahashi, T., Ohtsuki, T., Matsumoto, M. (2010). The pathophysiology of prospective memory failure after diffuse axonal injury - lesionsymptom analysis using diffusion tensor imaging. BMC neuroscience, November, 11:147, 7p.

[233] Korman, M., Doyon, J., Doljansky, J., Carrier, J., Dagan, Y., Karni, A. (2007). Daytime sleep condenses the time course of motor memory consolidation. Nature neuroscience, September, 10 (9), p.1206-1213.

[234] Korman, M., Raz, N., Flash, T., Karni, A. (2003). Multiple shifts in the representation of a motor sequence during the acquisition of skilled performance. Proceedings of the National Academy of Sciences of the United States of America, October, 100 (21), p.12492-12497.

[235] Korto, A. (1965). O fortepiannom iskusstve. Ed. Moscow, Muzyka, 364 p. [original: Kopтo, A. O фортепианном искусстве. (About forte-piano art.) изд. Москва, Музыка, 364 с.]

[236] Kosslyn, S. M., Behrmann, M., Jeannerod, M. (1995). The cognitive neuroscience of mental imagery. Neuropsychologia, 33 (11), p.1335-1344.

[237] Krakauer, J. W., Ghez, C., Ghilardi, M. F. (2005). Adaptation to visuomotor transformations: Consolidation, interference, and forgetting. Journal of neuroscience, January, 25 (2), p.473-478.

[238] Kubovy, M., van Valkenburg, D. (2001). Auditory and visual objects. Cognition, June, 80 (1-2), p.97-126.

[239] Kumaran, D., Maguire, E. A. (2006). The dynamics of hippocampal activation during encoding of overlapping sequences. Neuron, February, 49 (4), p.617-629.

[240] Kungurov, A. V. (2014). Muzykalnaja pamiat' i metody zaucivanija muzykalnych proizvedenij. Obrazovanie licnosti, 2, p.66-75. original: Кунгуров А.В. Музыкальная память и методы заучивания музыкальных произведений. (Musical memory and methods of memorizing musical works.) Образование личности, 2, с.66-75.]

[241] Kuriyama, K., Stickgold, R., Walker, M. P. (2004). Sleep-dependent learning and motor-skill complexity. Learning and memory, November-December, 11 (6), p.705-713. 
[242] Kvavilashvili, L., Ellis, J. (1996). Varieties of intentions: Some distinctions and classifications. In: M. Brandimonte, G. O. Einstein, M. A. McDaniel (eds.), Prospective memory: Theory and application. ed. Lawrence Erlbaum Associates, Publishers. 438 p., p.23-51.

[243] Lakatos, P., O’Connell, M. N., Barczak, A., Mills, A., Javitt, D. C., Schroeder, C. E. (2009). The leading sense: Supramodal control of neurophysiological context by attention. Neuron, November, 64 (3), p.419-430.

[244] Landsness, E. C., Crupi, D., Hulse, B. K., Peterson, M. J., Huber, R., Ansari, H., Coen, M., Cirelli, C., Benca, R. M., Ghilardi, M. F., Tononi, G. (2009). Sleep-dependent improvement in visuomotor learning: A causal role for slow waves. Sleep, October, 32 (10), p.1273-1284.

[245] Larsell, O., Jansen, O. (1972). The comparative anatomy and histology of the cerebellum: The human cerebellum, cerebellar connections and the cerebellar cortex. ed. Minneapolis, University of Minnesota Press, $284 \mathrm{p}$.

[246] Lebedev, A. N. (1985). Kodirovanie informacii v pamiati kogerentnymi volnami neironnoj aktivnosti. In: A. N. Lebedev. Psihofiziologiceskie zakonomernosti vosprijatija i pamiati. ed. Moscow, Nauka, 220 p., p.6-33. [original: Лебедев, А. Н. Кодирование информации в памяти когерентными волнами нейронной активности. (Coding information in memory by coherent waves of neural activity.) / А. Н. Лебедев. Психофизиологические закономерности восприятия и памяти. (Psychophysiological patterns of perception and memory.) изд. Москва, Наука. 220 с., с.6-33.]

[247] Lebedev, A. N. (1997). Psihofiziologija pamiati. In: J. I. Aleksandrov. Osnovy psihifiziologii. ed. Moscow, INFRA-M, 349 p., p.129-142. [original: Лебедев, А. Н. Психофизиология памяти. (Psychophysiology of memory.) / Ю. И. Александров. Основы психофизиологии. (Basics of psychophysiology.) изд. Москва, ИНФРА-М. 220 с., 349 с.129-142.]

[248] Lechun, X. (1994). A study on the relationship between short-term motor memory storage and precision and motor learning. Acta psychologica sinica, February, 26 (1), p.1-27.

[249] Lee, T. D., Swanson, L. R., Hall, A. L. (1991). What is repeated in a repetition? Effects of practice conditions on motor skill acquisition. Physical therapy, February, 71 (2), p.150-156.

[250] Lerner, Y., Papo, D., Zhdanov, A., Belozersky, L., Hendler, T. (2009). Eyes wide shut: Amygdala mediates eyes-closed effect on emotional experience with music. PLoS One, July, 4(7), e6230, 17 p.

[251] Levin, M. (2000). Spiritual intelligence. ed. Hodder Headline Australia. 357 p.

[252] Lewis, P. A., Couch, T. J., Walker, M. P. (2011). Keeping time in your sleep: Overnight consolidation of temporal rhythm. Neuropsychologia, January, 49 (1), p.115-123.

[253] LaBerge, D. (1995). Attentional processing in music listening: A cognitive neuroscience approach. Psychomusicology: A journal of research in music cognition, 14 (1-2), p.20-34.

[254] Lyakhovetskii, V. A., Bobrova, E. V. (2009). Vosproizvedenie zapomnennoj posledovatelnosti dvizhenij pravoj ilevoj ruki: Pozicionnoe i vektornoe kodirovanie. Zhurnal vysshej nervnoj dejatelnosci, 59 (1), p.45-54. [original: Ляховецкий, В. А., Боброва, Е. В. Воспроизведение запомненной последовательности движений правой и левой руки: Позиционное и векторное кодирование. (Reproduction of a memorized sequence of movements of the right and left hand: Positional and vector coding.) Журнал высшей нервной деятельности, 59 (1), c.45-54.]

[255] Lyakhovetskii, V. A., Bobrova, E. V. (2013). Vozrastnye izmienienija pri zapominanii posledovatelnostej dvizhenij vedusej i subdominantnoj ruki. Zhurnal vysshej nervnoj dejatelnosci, 63 (5), p.565-570. [original: Ляховецкий, В. А., Боброва, Е. В. Возрастные изменения при запоминании последовательности движений ведущей и субдоминантной руки. (Age-related changes in remembering the sequence of movements of the leading and subdominant hands.) Журнал высшей нервной деятельности, 63 (5), с.565-570.]

[256] Lyakhovetskii, V. A., Bobrova, E. V., Skopin, G. N. (2009). Oshibki perestanovok kak instrument issledovanija motornoj rabocej pamiati. Piatyj mezhdunarodnyj mezhdisciplinarnyj kongress 'Neironauka dla mediciny i psihologii’, Sudak, June 3-13, p.149-150. [original: Ляховецкий, В. А., Боброва, Е. В., Скопин, Г. Н. Ошибки перестановок как инструмент исследования моторной рабочей памяти. (Permutation errors as a tool for studying motor working meтоry.) Пятый международный междисииилинарный конгресс 'Нейронаука для медицины и психологии'. 3-13 июня, Судак, 2009. с. 149-150.]

[257] Lyakhovetskii, V. A., Bobrova, E. V., Skopin, G. N. (2012). Oshibki perestanovok pri obucenii vosproizvedeniju posledovatelnostej dvizhenij pravoj i levoj ruki: Modelirovanije kodirovanija polozhenij i dvizhenij. Zhurnal vysshej nervnoj dejatelnosci, 62 (6), p.681-691. [original: Ляховецкий, В. А., Боброва, Е. В., Скопин, Г. Н. Ошибки перестановок при обучении воспроизведению последовательностей движений правой и левой руки: Моделирование кодирования положений и движений. (Permutation errors when learning to play sequences of movements of the right and left hand: Modeling the encoding of positions and movements.) Журнал высшей нервной деятельности, 62 (6), с.681-691.] 
[258] Larsen, A., McIlhagga, W., Baert, J., Bundesen, C. (2003). Seeing or hearing? Perceptual independence, modality confusions, and crossmodal congruity effects with focused and divided attention. Perception and psychophysics, May, 65 (4), p.568-574.

[259] Lüer, G. (2007). Georg Elias Müller (1850-1934): A founder of experimental memory research in psychology. Cortex, July, 43 (5), p.579-582.

[260] Luria, A. R. (1973). Osnovy neiropsihologii. ed. Moscow, MGU, 374 р. [original: Лурия, А. Р. Основы нейропсихологии. (Basics of psychophysiology.) изд. Москва, МГУ, 374 с.]

[261] Luria, A. R. (1975). Vnimanie i pamiat'. ed. Moscow, MGU, 106 p. [original: Лурия, А. Р. Внимание и память. (Attention and тетоry.) изд. Москва, МГУ, 106 с.]

[262] Luria, A. R. (2000). Vysshie korkovyje funkciji celoveka i ich narushenija pri lokalnch porazhenijach mozga. ed. Moscow, Akademiceskij proekt. 505 p. [original: Лурия, А. Р. Высшие корковые функиии человека и их нарушения при локальных поражениях мозга. (Higher cortical functions of a person and their disorders in local brain lesions.) изд. Москва, Академический проект, 505 с.]

[263] Madsen, C. K., Geringer, J. M. (1990). Differential patterns of music listening: Focus of attention of musicians and nonmusicians. Bulletin of the council for research in music education, Summer, 105, p.45-57.

[264] Makkinon, L. (1967). Igra naizust’. ed. Leningrad, Muzyka, 217 р. [original: Маккиннон, Л. Игра наизусть. (Playing from memory.) изд. Ленинград, Музыка, 217 с.

[265] Maklakov, A. G. (2001). Obsiaja psihologia. ed. Saint-Petersburg, Piter. 592 p. [original: Маклаков А. Г. Общая психология. (General psychology.) изд. Санкт-Петербург, Питер. 592 с.]

[266] Malenka, R. C., Nestler, E. J., Hyman, S. E. (2015). Widely projecting systems: monoamines, acetylcholine, and orexin. In: A. Sydor, R.Y. Brown (eds.), Molecular neuropharmacology: a foundation for clinical neuroscience. Chapter 6. ed. New York, McGraw-Hill Medical. 544 p.

[267] Manns, J. R., Howard, M. W., Eichenbaum, H. (2007). Gradual changes in hippocampal activity support remembering the order of events. Neuron, November, 56 (3), p.530-540.

[268] Maquet, P., 2000. Sleep on it! Nature neuroscience, December, 3 (12), p.1235-1236.

[269] Maquet, P., Laureys, S., Peigneux, P., Fuchs, S., Petiau, C., Phillips, C., Aerts, J., Del Fiore, G., Degueldre, C., Meulemans, T., Luxen, A., Franck, G., Van Der Linden, M., Smith, C., Cleeremans, A. (2000). Experience-dependent changes in cerebral activation during human REM sleep. Nature neuroscience, August, 3 (8), p.831-836.

[270] Mariutina, T. M. (2020). Psihofiziologia: obsiaja, vozrastnaja, differencialnaja, kliniceskaja: ucebnik. ed.Moscow, INFRA-M, 436 p. [original: Марютина, Т. М. Психофизиология: общая, возрастная, дифференциальная, клиническая : учебник. (Psychophysiology: general, age, differential, clinical: textbook.) изд. Москва, ИНФРА-М. 436 с.]

[271] Martin, T., McDaniel, M. A., Guynn, M. J., Houck, J. M., Woodruff, C. C., Bish, J. P., Moses, S. N., Kicic, D., Tesche, C. D. (2007). Brain regions and their dynamics in prospective memory retrieval: A MEG study. International Journal of Psychophysiology, June, 64 (3), p.247-258.

[272] Martin, E. M., Nixon, H., Pitrak, D. L., Weddington, W., Rains, N. A., Nunnally, G., Grbesic, S., Gonzalez, R., Jacobus, J., Bechara, A. (2007). Characteristics of prospective memory deficits in HIV-seropositive substancedependent individuals: Preliminary observations. Journal of clinical and experimental neuropsychology. July, 29 (5), p.496-504.

[273] Martin, M., Schumann-Hengsteler, R. (2001). How task demands influence time-based prospective memory performance in young and older adults. International journal of behavioral development, 25 (4), p.386-391.

[274] Martinsen, K. A. (1966). Individualnaja fortepiannaja tehnika na osnove zvukotvorceskoj voli. ed. Moscow, Muzyka, 220 p. [original: Мартинсен, К. А. Индивидуальная фортепианная техника на основе звукотворческой воли. (Individual forte-piano technique based on sound-creative will.) изд. Москва, Музыка, $220 \mathrm{c.}]$

[275] Martinsen, K. A. (2002). Metodika individualnogo prepodavanija igry na fortepiano. ed. Moscow, Klassika XXI, 115 р. [original: Мартинсен, К. А. Методика индивидуального преподавания игры на фортепиано. (Methodology of individual teaching piano playing). изд. Москва, Классика XXI, 115 с.]

[276] Maruszewski, T. (2010). Pamięć autobiograficzna - nowe dane. (Autobiographic memory - new data.) Neuropsychiatria i neuropsychologia, 5, 3-4, p.122-129.

[277] McClelland, J. L., McNaughton, B. L., O’Reilly, R. C. (1995). Why there are complementary learning systems in the hippocampus and neocortex: insights from the successes and failures of connectionist models of learning and memory. Psychological review, July, 102 (3), p.419-457.

[278] McDaniel, M. A., Einstein, G. O. (2007). Prospective memory: An overview and synthesis of an emerging field. Ed. Thousand oaks, CA, SAGE Publications. 280 p. 
[279] McDaniel, M. A., Howard, D. C., Butler, K. M. (2008). Implementation intentions facilitate prospective memory under high attention demands. Memory and cognition, June, 36 (4), p.716-724.

[280] McErlee, B. (1998). Attended and non-attended states in working memory: Accessing categorized structures. Journal of memory and language, February, 38 (2), p.225-252.

[281] McErlee, B. Working memory and focal attention. (2001). Journal of experimental psychology: learning, memory and cognition, May, 27 (3), p.817-835.

[282] McGaugh, J. L. (2000). Memory - a century of consolidation. Science, January, 287 (5451), p.248-251.

[283] McGaugh, J. L. (2004). The amygdala modulates the consolidation of memories of emotionally arousing experiences. Annual review of neuroscience, 27, p.1-28.

[284] McGaugh, J. L., Cahill, L., Roozendaal, B. (1996). Involvement of the amygdala in memory storage: interaction with other brain systems. Proceedings of the National Academy of Sciences of the United States of America, November, 93 (24), p.13508-13514.

[285] Meacham J.A., Dumitru J. (1975). Prospective remembering and external retrieval cues. 13 p. ERIC Document Reproduction Service. ED 119859. [Downloaded on March $1^{\text {st }} 2020$ from: https://www.researchgate.net/publication/234655121_Prospective_Remembering_and_External_Retrieval_Cues]

[286] Meier, B., Cock, J. (2014). Offline consolidation in implicit sequence learning. Cortex, August, 57, p.156-166.

[287] Melton, A. W., Von Lackum, W. J. (1941). Retroactive and proactive inhibition in retention: evidence for a two-factor theory of retroactive inhibition. American journal of psychology, April, 54 (2), p.157-173.

[288] Mieshcheriakov, B., Zinchenko, V. P. (2009). Bolshoj psihologiceskij slovar'. ed. Moscow, AST Prajm-Evroznak, 816 p.[original: Мещеряков, Б., Зинченко, В. П. Большой психологический словарь. (Big psychological dictionary.) изд. Москва, АСТ, Прайм-Еврознак, 816 с.]

[289] Meyer, D. E., Smith, J. E., Wright, C. E. (1982). Models for the speed and accuracy of aimed movements. Psychological review, September, 89 (5), p.449-482.

[290] Miall, C. (2010). Motor control: correcting errors and learning from mistakes. Current biology, June, 20 (14), R596-R598.

[291] Middleton, F. A., Strick, P. L. (1997). Cerebellar output channels. In: J. Schmahmann (ed.), The cerebellum and cognition. ed. San Diego, Academic Press. 665 p., p.6-83.

[292] Miller, E. K., Cohen, J. D. (2001). An integrative theory of prefrontal cortex function. Annual review of neuroscience, 24, p.167-202.

[293] Moncada, D., Ballarini, F., Viola, H. (2015). Behavioral tagging: a translation of the synaptic tagging and capture hypothesis. Neural plasticity, art.650780, $21 \mathrm{p}$.

[294] Morey, C. C., Cowan, N. (2005). When do visual and verbal memories conflict? The importance of workingmemory load and retrieval. Journal of experimental psychology: Learning, memory, and cognition, July, 31 (4), p.703-713.

[295] Morgan, M., Bradshaw, J. L., Phillips, J. G., Mattingley, J. B., Iansek, R., Bradshaw, J. A. (1994). Effect of hand and age on abductive and adductive movements: a kinematic analysis. Brain and cognition, July, 25 (2), p.194-206.

[296] Moroni, F., Nobili, L., Curcio, G., De Carli, F., Tempesta, D., Marzano, C., De Gennaro, L., Mai, R., Francione, S., Lo Russo, G., Ferrara, M. (2008). Procedural learning and sleep hippocampal low frequencies in humans. Neuroimage, August, 42 (2), p.911-918.

[297] Morris, G. O., Williams, H. L., Lubin, A. (1960). Misperception and disorientation during sleep deprivation. A.M.A. Archives of general psychiatry, March, 2 (3), p.247-254.

[298] Moscovitch, M. (1994). Memory and working with memory: Evaluation of a component process model and comparisons with other models. In: D. L. Schacter, E. Tulving (eds.), Memory systems. ed. Cambridge, MA, Bradford book, MIT Press. 416 p., p.269-310.

[299] Mucmaher, V. I. (1984). Soversenstvovanie muzykalnoj pamiati v processe obucenija igre na fortepiano. ed. Moscow, Muzyka, 285 p. [original: Муцмахер, В. И. Совершенствование музыкальной памяти в процессе обучения игре на фортепиано. (Improving musical memory in the process of learning to play the piano.) изд. Москва, Музыка, 285 с.]

[300] Müller, G. E., Pilzecker, A. (1900). Experimentelle beitrage zur lehre vom gedachtnis. (Experimental contributions to the teaching of thought.) Zeitschrift fur psychologie, supplement no.1. (Journal of psychology, supplement no.1.) p.1-300.

[301] Mürbe, D., Pabst, F., Hofmann, G., Sundberg, J. (2004). Effects of a professional solo singer education on auditory and kinesthetic feedback - a longitudinal study of singers' pitch control. Journal of voice, June, 18 (2), p.236-241. 
[302] Mussa-Ivaldi, F. A., Bizzi, E. (2000). Motor learning through the combination of primitives. Philosophical transactions of the Royal Society of London, series b, biological sciences, December, 355 (1404), p.1755-1769.

[303] Mutha, P. K., Sainburg, R. L. (2007). Control of velocity and position in single joint movements. Human movement science, December, 26 (6), p.808-823.

[304] Napolitano, A. C., Sloutsky, V. M. (2004). Is a picture worth a thousand words? The flexible nature of modality dominance in young children. Child Development, November-December, 75 (6), p.1850-1870.

[305] Nemeth, D., Hallgató, E., Janacsek, K., Sándor, T., Londe, Z. (2009). Perceptual and motor factors of implicit skill learning. Neuroreport, December, 20 (18), p.1654-1658.

[306] Niedermeyer, E. (1997). "Alpha rhythms as physiological and abnormal phenomena". International journal of psychophysiology, June, 26 (1-3), p.31-49.

[307] Niedźwieńska, A. (2008). Pamięć prospektywna - poznawcze podstawy realizacji zamiarów. (Prospective memory - cognitive foundations for the implementation of intentions.) In: A. Niedźwieńska (ed.), Samoregulacja w poznaniu i działaniu. (Self-regulation in cognition and action.) ed. Kraków, wyd. Uniwersytetu Jagiellońskiego, p.73-101.

[308] Nikolaeva, E. (2019). Psihofiziologia. Ucebnik. ed. Saint-Petersburg, Piter, 704 p. [original: Николаева, Е. Психофизиология. Учебник. (Psychophysiology. Textbook.) изд. Санкт-Петербург, Питер. 704 с.]

[309] Nitsche, M. A., Jakoubkova, M., Thirugnanasambandam, N., Schmalfuss, L., Hullemann, S., Sonka, K., Paulus, W., Trenkwalder, C., Happe, S. (2010). Contribution of the premotor cortex to consolidation of motor sequence learning in humans during sleep. Journal of neurophysiology, November, 104 (5), p.2603-2614.

[310] Oberauer, K. (2001). Removing irrelevant information from working memory: A cognitive aging study with the modified Sternberg task. Journal of experimental psychology. Learning, memory and cognition, July, 27 (4), p.948-957.

[311] Oberauer, K. (2002). Access to information in working memory: exploring the focus of attention. Journal of experimental psychology. Learning, memory and cognition, May, 28 (3), p.411-421.

[312] Ohman, A., Flykt, A., Esteves, F. (2001). Emotion drives attention: Detecting the snake in the grass. Journal of Experimental Psychology. General, September, 130 (3), p.466-478.

[313] Orban, P., Peigneux, P., Lungu, O., Debas, K., Barakat, M., Bellec, P., Benali, H., Maquet, P., Doyon, J. (2011). Functional neuroanatomy associated with the expression of distinct movement kinematics in motor sequence learning. Neuroscience, April, 179, p.94-103.

[314] Osipova, V. N. (2010). Vozrastnaja fiziologia $i$ psihofiziologia. Moscow, ed. MGIU, 190 p. [original: Осипова, B. H. Возрастная физиология и психофизиология. (Age-related physiology and psychophysiology.) изд. Москва, МГИУ. 190 с.]

[315] Overduin, S. A., Richardson, A. G., Bizzi, E., Press, D. Z. (2008). Simultaneous sensorimotor adaptation and sequence learning. Experimental brain research, January, 184 (3), p.451-456.

[316] Pace-Schott, E. F., Spencer, R. M. C. (2013). Age-related changes in consolidation of perceptual and muscle-based learning of motor skills. Frontiers in aging neuroscience, November, 5, art.83, 7 p.

[317] Paillard, J. (1991). Motor and representational framing of space. In: J. Paillard (ed.), Brain and Space. ed. Oxford, Oxford University Press. 512 p., p.163-182.

[318] Peigneux, P., Laureys, S., Fuchs, S., Destrebecqz, A., Collette, F., Delbeuck, X., Phillips, C., Aerts, J., Del Fiore, G., Degueldre, C., Luxen, A., Cleeremans, A., Maquet, P. (2003). Learned material content and acquisition level modulate cerebral reactivation during posttraining rapid-eye-movements sleep. Neuroimage, September, 20 (1), p.125-134.

[319] Peigneux, P., Laureys, S., Fuchs, S., Collette, F., Perrin, F., Reggers, J., Phillips, C., Degueldre, C., Del Fiore, G., Aerts, J., Luxen, A., Maquet, P. (2004). Are spatial memories strengthened in the human hippocampus during slow wave sleep? Neuron, October, 44 (3), p.535-545.

[320] Pekrun, R. (1992). The impact of emotions on learning and achievement: towards a theory of cognitive/motivational mediators. Applied psychology: An international review, 41 (4), p.359-376.

[321] Penhune, V. B., Doyon, J. (2002). Dynamic cortical and subcortical networks in learning and delayed recall of timed motor sequences. Journal of neuroscience, February, 22 (4), p.1397-1406.

[322] Penhune, V. B., Doyon, J. (2005). Cerebellum and M1 interaction during early learning of timed motor sequences. Neuroimage, July, 26 (3), p.801-812.

[323] Penhune, V. B., Steele, C. J. (2012). Parallel contributions of cerebellar, striatal and M1 mechanisms to motor sequence learning. Behavioural brain research, January, 226 (2), p.579-591.

[324] Perennou, D. A., Leblond, C., Amblard, B., Micallef, J. P., Rouget, E., Pelissier, J. (2000). The polymodal sensory cortex is crucial for controlling lateral postural stability: evidence from stroke patients. Brain research bulletin, October, 53 (3), p.359-365. 
[325] Pessoa, L. (2008). On the relationship between emotion and cognition. Nature reviews. Neuroscience, February, 9 (2), p.148-158.

[326] Petrus, E., Isaiah, A., Jones, A. P., Li, D., Wang, H., Lee, H. K., Kanold, P. O. (2014). Crossmodal induction of thalamocortical potentiation leads to enhanced information processing in the auditory cortex. Neuron, February, 81 (3), p.664-673.

[327] Petrushin, V. I. (2020). Muzykalnaja psihologia. ed. Moscow, Jurajt. 380 p. [original: Петрушин, В. И. Музыкальная психология. (Musical psychology.) изд. Москва, Юрайт, 380 с.]

[328] Phelps, E. A. (2006). Emotion and cognition: insights from studies of the human amygdale. Annual review of psychology, 57, p.27-53.

[329] Phillips, L. H., Henry, J. D., Martin, M. (2008). Adult aging and prospective memory: The importance of ecological validity. In: M. Kliegel, M. A., McDaniel, G. O. Einstein (eds.), Prospective memory: Cognitive, neuroscience, developmental, and applied perspectives. Chapter 8. ed. New York, Taylor and Francis Group, Lawrence Erlbaum Associates. 488 p., p.161-185.

[330] Plihal, W., Born, J. (1997). Effects of early and late nocturnal sleep on declarative and procedural memory. Journal of cognitive neuroscience, July, 9 (4), p.534-547.

[331] Polit, A., Bizzi, E. (1979). Characteristics of motor programs underlying arm movements in monkeys. Journal of neurophysiology, January, 41 (1 part 1), p.183-194.

[332] Poppenk, J., Moscovitch, M., McIntosh, A. R., Ozcelik, E., Craik, F. I. (2010). Encoding the future: successful processing of intentions engages predictive brain networks. Neuroimage, January, 49 (1), p.905-913.

[333] Postma, A., Laeng, B. (2006). New insights in categorical and coordinate processing of spatial relations. Neuropsychologia, 44 (9), p.1515-1518.

[334] Pratto, F., John, O. P. (1991). Automatic vigilance: The attention-grabbing power of negative social information. Journal of personality and social psychology, September, 61 (3), p.380-391.

[335] Preston, A. R., Eichenbaum, H. (2013). Interplay of hippocampus and prefrontal cortex in memory. Current biology, September, 23 (17), R764-R773.

[336] Phelps, E. A. (2004). Human emotion and memory: interactions of the amygdala and hippocampal complex. Current opinion in neurobiology, April, 14 (2), p.198-202.

[337] Radvansky, G. A., Fleming, K. J., Simmons, J. A. (1995). Timbre reliance in nonmusicians' and musicians' memory for melodies. Music perception, Winter, 13 (2), p.127-140.

[338] Ramnani, N. (2006). The primate cortico-cerebellar system: anatomy and function. Nature reviews. Neuroscience. July, 7 (7), p.511-522.

[339] Randel, D. M. (2003).The Harvard dictionary of Music, ed. Cambridge: The Belknap Press for Harvard University Press. 1008 p.

[340] Rasch, B., Büchel, C., Gais, S., Born, J. (2007). Odor cues during slow-wave sleep prompt declarative memory consolidation. Science, March, 315 (5817), p.1426-1429.

[341] Reinmann, B., McNally, R. J. (1995). Cognitive processing of personally relevant information. Cognition and emotion, 9, p.325-340.

[342] Rendell, P. G., Gray, T. J., Henry, J. D., Tolan, A. (2007). Prospective memory impairment in 'ecstasy' (MDMA) users. Psychopharmacology, November, 194 (4), p.497-504.

[343] Reynolds, J. R., West, R., Braver, T. (2009). Distinct neural circuits support transient and sustained processes in prospective memory and working memory. Cerebral cortex, May, 19 (5), p.1208-1221.

[344] Richardson, M. P., Strange, B. A., Dolan, R. J. (2004). Encoding of emotional memories depends on amygdala and hippocampus and their interactions. Nature neuroscience, March, 7 (3), p.278-285.

[345] Richter-Levin, G., Akirav, I. (2000). Amygdala-hippocampus dynamic interaction in relation to memory. Molecular neurobiology, August-December, 22 (1-3), p.11-20.

[346] Rieber, R. W., Salzinger, K. D. (1999). Psychology: Theoretical-historical perspectives. ed. Washington, DC, American Psychological Association. 509 p.

[347] Rieckmann, A., Fischer, H., Bäckman, L. (2010). Activation in striatum and medial temporal lobe during sequence learning in younger and older adults: relations to performance. Neuroimage, April, 50 (3), p.1303-1312.

[348] Rimski-Korsakov, N. A. (1911). Muzykalnyje statji i zamietki. ed. Saint-Petersburg, tip M. Stasiulevicha, 223 p. [original: Римский-Корсаков, Н. А. Музыкальные статьи и заметки. (Music articles and notes). изд. Санкт-Петербург, тип. М. Стасюлевича. 223 с.]

[349] Robertson, E. M., Pascual-Leone, A., Press, D. Z. (2004). Awareness modifies the skill-learning benefits of sleep. Current biology, February, 14 (3), p.208-212.

[350] Robertson, E. M. (2012). New insights in human memory interference and consolidation. Current biology, January, 22 (2), R66-R71. 
[351] Robinson, C. W. Sloutsky, V. M. (2004). Auditory dominance and its change in the course of development. Child Development, September-October, 75 (5), p.1387-1401.

[352] Rose, M., Haider, H., Salari, N., Büchel, C., 2011. Functional dissociation of hippocampal mechanism during implicit learning based on the domain of associations. Journal of neuroscience, September, 31 (39), p.13739-13745.

[353] Seligman, M. E. P., Walker, E. F., Rosenhan, D. L. (1994). Psychopatologia. (Psychopathology.) ed. Poznań, ZYSK I SK-A, 864 p.

[354] Ross, R. S., Brown, T. I., Stern, C. E. (2009). The retrieval of learned sequences engages the hippocampus: Evidence from fMRI. Hippocampus, September, 19 (9), P.790-799.

[355] Rossetti, Y. (1998). Implicit short-lived motor representations of space in brain damaged and healthy subjects. Consciousness and cognition, 7 (3), p.520-528.

[356] Rossing, T. D., Moore, F. R., Wheeler, P. A. (2001). The science of sound. ed. MA, Addison-Wesley Publishing Company, $680 \mathrm{p}$.

[357] Rubia, K. (2006). The neural correlates of timing functions. In: J. Glicksohn, M. S. Myslobodsky (eds.), Timing the future. The case for a time-based prospective memory. ed. Singapore, World Scientific Publishing Company. 324 p., p.213-238.

[358] Sacks, O. (1986). The man who mistook his wife for a hat. ed. London, Pan, Picador. 272 p.

[359] Sainburg, R. L., Duff, S. V. (2006). Does motor lateralization have implications for stroke rehabilitation? Journal of rehabilitation research and development, May-June, 43 (3), p.311-322.

[360] Saults, J. S., Cowan, N. A. (2007). A central capacity limit to the simultaneous storage of visual and auditory arrays in working memory. Journal of experimental psychology. General. November, 136 (4), p.663-684.

[361] Sauseng, P., Klimesch, W., Schabus, M., Doppelmayr, M. (2005). Fronto-parietal EEG coherence in theta and upper alpha reflect central executive functions of working memory. International journal of psychophysiology, August, 57 (2), p.97-103.

[362] Savion-Lemieux, T., Bailey, J. A., Penhune, V. B. (2009). Developmental contributions to motor sequence learning. Experimental brain research, May, 195 (2), p.293-306.

[363] Savion-Lemieux, T., Penhune, V. B. (2005). The effects of practice and delay on motor skill learning and retention. Experimental brain research, March, 161 (4), p.423-431.

[364] Savishinskij, S. I. (2020). Rabota pianista nad muzykalnym proizvedeniem. ed. Saint-Petersburg, Planeta muzyki, 192 p. [original: Савишинский, С. И. Работа пианиста над музыкальным произведением. (Pianist's work on a musical work.) Санкт-Петербург, изд. Планета музыки. 192 с.]

[365] Sawaki, L., Yaseen, Z., Kopylev, L., Cohen, L. G. (2003). Age-dependent changes in the ability to encode a novel elementary motor memory. Annals of neurology, April, 53 (4), p.521-524.

[366] Schacter, D. L., Gilbert, D. T., Nock, M. K., Wegner, D. M. (2016). Psychology. ed. New York, Worth Publishers. $832 \mathrm{p}$.

[367] Schaefer, S. Y., Haaland, K. Y., Sainburg, R. L. (2009). Hemispheric specialization and functional impact of ipsilesional deficits in movement coordination and accuracy. Neuropsychologia, November, 14 (13), p.2953-2966.

[368] Schendan, H. E., Searl, M. M., Melrose, R. J., Stern, C. E. (2003). An fMRI study of the role of the medial temporal lobe in implicit and explicit sequence learning. Neuron, March, 37 (6), p.1013-1025.

[369] Schmahmann. J. D. (1997). The cerebellum and cognition. Neuroscience letters, January, 688, p.62-75.

[370] Schmidt, R. A., Zelaznik, H. N., Hawkins, B., Frank, J. S., Quinn, J. T. (1979). Motor output variability: a theory for the accuracy of rapid motor acts. Psychological review, September, 85 (5), p.415-451.

[371] Schmidt, R. A. (1975). A schema theory of discrete motor skill learning. Psychological review, 82 (4), p. $225-260$

[372] Schnack, B., Klimesch, W., Sauseng, P. (2005). Phase synchronization between theta and alpha oscillations in a working memory task. International journal of psychophysiology, August, 57 (2), p.105-114.

[373] Schneider, W., Shiffrin, R. M. (1977). Controlled and automatic human information processing: I. Detection, search, and attention. Psychological review, 84 (1), p.1-66.

[374] Schönauer, M., Grätsch, M., Gais, S. (2015). Evidence for two distinct sleep-related long-term memory consolidation processes. Cortex, February, 63, p.68-78.

[375] Schultz, W. (2004). Neural coding of basic reward terms of animal learning theory, game theory, microeconomics and behavioural ecology. Current opinion in neurobiology, April, 14 (2), p.139-147.

[376] Schupp, H. T., Stockburger, J., Codispoti, M., Junghöfer, M., Weike, A. I., Hamm, A. O. (2007). Selective visual attention to emotion. Journal of neuroscience, January, 27 (5), p.1082-1089. 
[377] Shvyrkov, V. B. (1985). Psihofiziologiceskoje izucenie struktury subjektivnogo otrazhenija. Psihologiceskij zurnal, 6 (3), p.22-37. [original: Швырков, В. Б. Психофизиологическое изучение структуры субъективного отражения. (Psychophysiological study of the structure of subjective reflection.) Психологический журнал, 6 (3), с.22-37.]

[378] Scullin, M. K., McDaniel, M. A. (2010). Remembering to execute a goal: Sleep on it! Psychological Science, July, 21 (7), p.1028-1035.

[379] Sevostjanov, D. A. (2017). Psihofiziologia professjonalnoj dejatelnosti. ed. Novosibirsk, IC NGAU Zolotoj kolos, 207 p. [original: Севостьянов, Д. А. Психофизиология профессиональной деятельности. (Psychophysiology of professional activity.) изд. Новосибирск, ИЦ НГАУ Золотой колос. 207 с.]

[380] Seli, P., Wammes, J. D., Risko, E. F., Smilek, D. (2016). On the relation between motivation and retention in educational contexts: the role of intentional and unintentional mind wandering. Psychonomic bulletin and review, August, 23 (4), p.1280-1287.

[381] Seregin, V. J. (2009). Psihofiziologiceskie mehanizmy vosprijatija:koncepcija objemliushchih sensornyh harakteristik. Uspehi fiziologiceskih nauk, 40 (4), p.42-63. [original: Серегин, В. Я. Психофизиологические механизмы восприятия: концепция объемлющих сенсорных характеристик. (Psychophysiological mechanisms of perception: the concept of encompassing sensory characteristics.) Успехи физиологических наук, 40 (4), c.42-63.]

[382] Sergin, V. J. (2011). Soznanie i myshlenie: neirobiologiceskie mechanizmy. Psihologiceskij zhurnal mezhdunarodnogo universiteta prirody, obsiestva i celoveka 'Dubna', 2, p.7-34. [original: Сергин, В. Я. Сознание и мылиление: нейробиологические механизмы. (Consciousness and thinking: neurobiological mechanisms.) Психологический журнал Международного университета природь, общества и человека 'Дубна', 2, с.7-34.]

[383] Serences, J. T. (2008).Value-based modulations in human visual cortex. Neuron, December, 60 (6), p.1169-1181.

[384] Shadmehr, R., Brashers-Krug, T. (1997). Functional stages in the formation of human long-term motor memory. Journal of neuroscience, January, 17 (1), p.409-419.

[385] Shadmehr, R., Krakauer, J. W. (2008). A computational neuroanatomy for motor control. Experimental brain research, March, 185 (3), p.359-381.

[386] Shamma, S. A., Elhilali, M., Micheyl, C. (2011). Temporal coherence and attention in auditory scene analysis. Trends in neurosciences, March, 34 (3), p.114-123.

[387] Sharot, T., Delgado, M. R., Phelps, E. A. (2004). How emotion enhances the feeling of remembering. Nature neuroscience, December, 7 (12), p.1376-1380.

[388] Silberman, E. K., Weingartner, H. (1986). Hemispheric lateralization of functions related to emotion. Brain and cognition, July, 5 (3), p.322-353.

[389] Simons, J. S., Schölvinck, M. L., Gilbert, S. J., Frith, C. D., Burgess, P. W. (2006). Differential components of prospective memory? Evidence from fMRI. Neuropsychologia, 44 (8), p.1388-1397.

[390] Sink, P. E. (1983). Effects of rhythmic and melodic alterations on rhythmic perception. Journal of research in music education, July, 31 (2), p.101-113.

[391] Slotnick, S. D., Moo, L. R., Tesoro, M. A., Hart, J. (2001). Hemispheric asymmetry in categorical versus coordinate visuospatial processing revealed by temporary cortical deactivation. Journal of cognitive neuroscience, November, 13 (8), p.1088-1096.

[392] Sloutsky, V. M., Napolitano, A. C. (2003). Is a picture worth a thousand words? Preference for auditory modality in young children. Child Development, May-June, 74 (3), p.822-833.

[393] Smith, C., MacNeill, C. (1994). Impaired motor memory for a pursuit rotor task following Stage 2 sleep loss in college students. Journal of sleep research, December, 3 (4), p.206-213.

[394] Smith, C. D., Walton, A., Loveland, A. D., Umberger, G. H., Kryscio, R. J., Gash, D. M. (2005). Memories that last in old age: motor skill learning and memory preservation. Neurobiology of aging, June, 26 (6), p.883-890.

[395] Smith, R. E. (2003). The cost of remembering to remember in event-based prospective memory: investigating the capacity demands of delayed intention performance. Journal of experimental psychology. Learning, memory and cognition. May, 29 (3), p.347-361.

[396] Smith, R. E., Bayen, U. J. (2004). A multinomial model of event-based prospective memory. Journal of experimental psychology. Learning, memory and cognition. July, 30 (4), p.756-777.

[397] Sokolov, E. N. (1969). Mehanizm pamiati. Opyt eksperimentalnogo issledovanija. ed. Moscow, MGU, 176 p. [original: Соколов, Е. Н. Механизм памяти. Опыт экспериментального исследования. (Memory mechanism. Experimental research experience.) изд. Москва, МГУ, 176 с.]

[398] Song, S., Cohen, L. G. (2014). Practice and sleep form different aspects of skill. Nature communications, May, 5 , art. 3407. $16 \mathrm{p}$. 
[399] Song, J., Irwin, J., Dean, C. (2013). Remembering the prolonged cold of winter. Current biology, September, 23 (17), R807-R811.

[400] Spencer, R. M., Sunm, M., Ivry, R. B. (2006). Sleep-dependent consolidation of contextual learning. Current biology, May, 16 (10), p.1001-1005.

[401] Steele, Ch. J., Penhune, V. B. (2010). Specific increases within global decreases: a functional magnetic resonance imaging investigation of five days of motor sequence learning. Journal of neuroscience, June, 30 (24), p.8332-8341.

[402] Stickgold, R., Scott, L., Rittenhouse, C., Hobson, J. A. (1999). Sleep-induced changes in associative memory. Journal of cognitive neuroscience, March, 11 (2), p.182-193.

[403] Stickgold, R.,Walker, M. P. (2005). Memory consolidation and reconsolidation: what is the role of sleep? Trends in neurosciences, August, 28 (8), p.408-415.

[404] Still, A. W. (1969). Proactive interference and spontaneous alternation in rats. Quarterly journal of experimental psychology, November, 21 (4), p.339-345.

[405] Stock, J. B., Zhang, S. (2013) The biochemistry of memory. Current biology, September, 23 (17), R741-R745.

[406] Stoddard, J., Vaid, J. (1996). Asymmetries in intermanual transfer of maze learning in right- and left- handed adults. Neuropsychologia, June, 34 (6), p.605-608.

[407] Stojanov, A. A. (1958). Iskusstvo pianista. ed. Moscow, GMI, 148 p. [original: Стоянов, А. А. Искусство пианиста. (The art of the pianist.) изд. Москва, ГМИ, 148 с.]

[408] Stuart-Hamilton, I. (2006). Psychologia starzenia się. (Psychology of aging.) ed. Poznań, ZYSK I SK-A, 303 p.

[409] Stuss, D. T., Benson, D. F. (1984). Neuropsychological studies of the frontal lobes. Psychological Bulletin, January, 95 (1), p.3-28.

[410] Sundberg, J., Prame, E., Iwarsson, J. (1996). Replicability and accuracy of pitch patterns in professional singers. In: P. J. Davis, N. H. Fletcher (eds.), Vocal fold physiology: Controlling complexity and chaos. ed. San Diego, CA, Singular Publishing Group, Vocal fold psychology series. 433 p., p.291-306.

[411] Sussman, E. S., Horvath, J., Winkler, I., Orr, M. (2007). The role of attention in the formation of auditory streams. Perception and psychophysics, January, 69 (1), p.136-152.

[412] Suvorov, N. F., Tairov, O. P. (1985). Psihofiziologiceskie mehanizmy izbiratelnogo vnimanija. ed. Leningrad, Nauka, 288 p. [original: Суворов, Н. Ф., Таиров, О. П. Психофизиологические механизмы избирательного внимания. (Psychophysiological mechanisms of selective attention.) изд. Ленинград, Наука, 288 с.]

[413] Szelag, E. (1997). Temporal integration of the brain as studied with the metronome paradigm. In: H. Atmanspacher, E. Ruhnau (eds.), Time, temporality, now. Part.II. Experiencing Time and Concepts of Time in an Interdisciplinary Perspective. ed. Springer-Verlag Berlin Heidelberg. 383 p., p.121-131.

[414] Szelag, E., Kanabus, M., Kolodziejczyk, I., Kowalska, J., Szuchnik, J. (2004). Individual differences in temporal information processing in humans. Acta neurobiologiae experimentalis, 64 (3), p.349-366.

[415] Szelag, E., Steinbuchel, N., Reiser, M., de Lengen, E. G., Poppel, E. (1996). Temporal constraints in processing of nonverbal rhythmic patterns. Acta neurobiologiae experimentalis, 56 (1), p.215-225.

[416] Talsma, D., Doty, T. J., Woldorff, M. G. (2007). Selective attention and audiovisual integration: Is attending to both modalities a prerequisite for early integration? Cerebral cortex, March, 17 (3), p.679-690.

[417] Tamaki, M., Matsuoka, T., Nittono, H., Hori, T. (2008). Fast sleep spindle (13-15 hz) activity correlates with sleep-dependent improvement in visuomotor performance. Sleep, February, 31 (2), p.204-211.

[418] Tamaki, M., Matsuoka, T., Nittono, H., Hori, T. (2009). Activation of fast sleep spindles at the premotor cortex and parietal areas contributes to motor learning: a study using sLORETA. Clinical neurophysiology, May, 120 (5), p.878-886.

[419] Terekhin, A. T., Budilova, E. V., Kachalova, L. M., Karpenko, M. P. (2009). Nejrosetevoe modelirovanie kognitivnyh funkcji mozga: Obzor osnovnyh idej. Psihologiceskije issledovanija, 2 (4), 34 p. [original: Терехин, А. Т., Будилова, Е. В., Качалова, Л. М., Карпенко, М. П. Нейросетевое моделирование когнитивных функций мозга: обзор основных идей. (Neural network modeling of brain cognitive functions: review of basic ideas.) Психологические исследования, 2 (4), 34 с.]

[420] Ternström, S., Sundberg, J., Collden, J. (1983). Articulatory perturbation of pitch in singers deprived of auditory feedback. In: A. Askenfelt., S. Felicette, E. Jansson, J. Sundberg (eds.), SMAC 83. Proceedings of the Stockholm Music Acoustics Conference, July 28 - August 1, volume 1, 343 p., p.291-304.

[421] Teplov, B. M. (1947). Psihologia muzykalnyh sposobnostej. ed. Moscow - Leningrad, Institut psihologii APN RSFSR, 335 p. [original: Теплов, Б. М. Психология музыкальных способностей. (Psychology of musical abilities.) изд. Москва - Ленинград, Институт психологии АПН РСФСР, 335 с.]

[422] Terrett, G,, McLennan, S. N., Henry, J. D., Biernacki, K., Mercuri, K., Curran, H. V., Rendell, P. G. (2014). Prospective memory impairment in long-term opiate users. Psychopharmacology, January, 231 (13), p.2623-2632. 
[423] Toga A.W., Thompson, P. M. (2003). Mapping brain asymmetry. Nature reviews. Neuroscience. January, 4 (1), p.37-48.

[424] Troyer, A. K, Murphy, K. J. (2007). Memory for intentions in amnestic mild cognitive impairment: Time-and event-based prospective memory. Journal of the international neuropsychological society, March, 13 (2), p.365-369.

[425] Tupper, K. W. (2002). Entheogens and existential intelligence: The use of plant teachers as cognitive tools. Canadian journal of education, January, 27 (4), p.499-516.

[426] Tyng, Ch. M., Amin, H. U., Saad, M. N. M., Malik, A. S. (2017). The influences of emotion on learning and memory. Frontiers in psychology, August, 8, art.1454, 22 p.

[427] Uhtomskij, А. А. (2002). Dominanta. ed. Sankt-Peterburg, Piter. 448 р. [original: Ухтомский, А. А. Доминанта. (Dominant). изд. Санкт-Петербург, Питер. 448 с.]

[428] Urbain, C., Schmitz, R., Schmidt, C., Cleeremans, A., Van Bogaert, P., Maquet, P., Peigneux, P. (2013). Sleep-dependent neurophysiological processes in implicit sequence learning. Journal of cognitive neuroscience, November, 25 (11), p.2003-2014.

[429] Van Der Ham, I. J., Borst, G. (2011). Individual differences in spatial relation processing: Effects of strategy, ability, and gender. Brain and cognition, June, 76 (1), p.184-190.

[430] Van Der Werf, Y. D., Van Der Helm, E., Schoonheim, M. M., Ridderikhoff, A., Van Someren, E. J. W. (2009). Learning by observation requires an early sleep window. Proceedings of the National Academy of Sciences of the United States of America, November, 106 (45), p.18926-18930.

[431] Van Mier, H. I., Petersen, S. E. (2006). Intermanual transfer effects in sequential tactuomotor learning: Evidence for effector independent coding. Neuropsychologia, 44 (6), p.939-949.

[432] Van Mier, H., Tempel, L. W., Perlmutter, J. S., Raichle, M. E., Petersen, S. E. (1998). Changes in brain activity during motor learning measured with PET: effects of hand of performance and practice. Journal of neurophysiology, October, 80 (4), p.2177-2199.

[433] Velichkovsky, B. B. (2014). Pozicionnye efekty v rabocej pamiati. Eksperimentalnaja psihologia, 7 (2), p.26-36. [original: Величковский, Б. Б. Позиционные эффекты в рабочей памяти. (Positional effects in working тетогу.) Экспериментальная психология, 7 (2), с.26-36.]

[434] Verweij, I. M., Onuki, Y., Van Someren, E. J., Van Der Werf, Y. D. (2016). Sleep to the beat: a nap favours consolidation of timing. Behavioral neuroscience, June, 130 (3), p.298-304.

[435] Volle, E., Gonen-Yaacovi, G., Costello Ade L., Gilbert, S. J., Burgess, P. W. (2011). The role of rostral prefrontal cortex in prospective memory: A voxel-based lesion study. Neuropsychologia, July, 49 (8), p.2185-2198.

[436] Vuilleumier, P. (2005). How brains beware: neural mechanisms of emotional attention. Trends in cognitive sciences, December, 9 (12), p.585-594.

[437] Vurma, A., Ross, J., Ogorodnikova, E. (2006). Vosprijatie vokalnyh muzykalnyh intervalov. Sensornye sistemy, 20 (2), p.102-111. [original: Вурма, А., Росс, Я., Огородникова, Е. Восприятие вокальных музыкальных интервалов. (Perception of vocal musical intervals.) Сенсорные системы, 20 (2), с.102-111.]

[438] Vygotskij, L. S. (1991). Voobrazenie i tvorcestvo v detskom vozraste. ed. Moscow, Prosvieshchenie, 93 p. [original: Выготский Л. С. Воображение и творчество в детском возрасте. (Imagination and creativity in childhood.) изд. Москва, Просвещение, 93 с.]

[439] Wagner, U., Gais, S., Born, J. (2001). Emotional memory formation is enhanced across sleep intervals with high amounts of rapid eye movement sleep. Learning and memory, March-April, 8 (2), p.112-119.

[440] Wagner, U., Gais, S., Haider, H., Verleger, R., Born, J. (2004). Sleep inspires insight. Nature, January, 427 (6972), p.352-355.

[441] Wagner, U., Hallschmid, M., Rasch, B., Born, J. (2006). Brief sleep after learning keeps emotional memories alive for years. Biological psychiatry, October, 60 (7), p.788-790.

[442] Walker, M. P., Brakefield, T., Hobson, J. A., Stickgold, R. (2003). Dissociable stages of human memory consolidation and reconsolidation. Nature, October, 425 (6958), p.616-620.

[443] Walker, M. P., Brakefield, T., Morgan, A., Hobson, J. A., Stickgold, R. (2002). Practice with sleep makes perfect: sleep dependent motor skill learning. Neuron, July, 35 (1), p.205-211.

[444] Walker, M. P., Brakefield, T., Seidman, J., Morgan, A., Hobson, J. A., Stickgold, R. (2003). Sleep and the time course of motor skill learning. Learning and memory, July, 10 (4), p.275-284.

[445] Walker, M. P., Liston, C., Hobson, J. A., Stickgold, R. (2002). Cognitive flexibility across the sleep-wake cycle: REM-sleep enhancement of anagram problem solving. Brain research. Cognitive brain research. November, 14 (3), p.317-324.

[446] Walker, M. P., Stickgold, R., Alsop, D., Gaab, N., Schlaug, G. (2005). Sleep-dependent motor memory plasticity in the human brain. Neuroscience, 133 (4), p.911-917.

[447] Walsh K., Darby D. (2014). Neuropsychologia kliniczna. (Clinical neuropsychology.) ed. Gdańsk, GWP. 552 p. 
[448] Ward, W. D. (1970). Musical perception. In: J. Tobias. Foundations of modern auditory theory. ed. New York, Academic Press. 484 p., p.405-447.

[449] Warrier, C. M., Zatorre, R. J. (2002). Influence of tonal context and timbral variation on perception on pitch. Perception and psychophysics, February, 64 (2), p.198-207.

[450] Watanabe, D., Savion-Lemieux, T., Penhune, V. B. (2007). The effect of early musical training on adult motor performance: Evidence for a sensitive period in motor learning. Experimental brain research, January, 176 (2), p.332-340.

[451] Weinborn, M., Moyle, J., Bucks, R. S., Stritzke, W., Leighton, A., Woods, S. P. (2013). Time-based prospective memory predicts engagement in risk behaviors among substance users: results from clinical and nonclinical samples. Journal of the international neuropsychological society, March, 19 (3), p.284-294.

[452] West R. (2008). The cognitive neuroscience of prospective memory. In: M. Kliegel, M. A., McDaniel, G. O. Einstein (eds.), Prospective memory: Cognitive, neuroscience, developmental, and applied perspectives. Chapter 12. ed. New York, Taylor and Francis Group, Lawrence Erlbaum Associates. 488 p., p.261-282.

[453] Wilhelm, I., Diekelmann, S., Molzow, I., Ayoub, A., Mölle, M., Born, J. (2011). Sleep selectively enhances memory expected to be of future relevance. Journal of neuroscience, February, 31 (5), p.1563-1569.

[454] Wilhelm, I., Metzkow-Mészàros, M., Knapp, S., Born, J. (2012). Sleep-dependent consolidation of procedural motor memories in children and adults: the pre-sleep level of performance matters. Developmental science, July, 15 (4), p.506-515.

[455] Wilhelm, I., Rose, M., Imhof, K. I., Rasch, B., Büchel, C., Born, J. (2013). The sleeping child outplays the adult's capacity to convert implicit into explicit knowledge. Nature neuroscience, April, 16 (4), p.391-393.

[456] Williams, J. M., Mathews, A., MacLeod, C. (1996). The emotional Stroop task and psychopathology. Psychological Bulletin, July, 120 (1), p.3-24.

[457] Willingham, D. B. (1998). A neuropsychological theory of motor skill learning. Psychological review, July, 105 (3), p.558-584.

[458] Willingham, D. B. (1999). Implicit motor sequence learning is not purely perceptual. Memory and cognition, May, 27 (3), p.561-572.

[459] Witkowska, M. (2010). Pamięć prospektywna: od teorii do praktyki. (Prospective memory: from theory to practice.) In: K. Jodzio, E. M. Szepietowska (eds.), Neuronalne ścieżki poznania i zachowania. (Neural paths of knowledge and behavior.) ed. Lublin, UMCS. 228 p., p.29-42.

[460] Witt, K., Margraf, N., Bieber, C., Born, J., Deuschl, G. (2010). Sleep consolidates the effector-independent representation of a motor skill. Neuroscience, November, 171 (1), p.227-234.

[461] Wittmann, M. (1999). Time perception and temporal processing levels of the brain. Chronobiology international, January, 16 (1), p.17-32.

[462] Wittmann, M. (2013). The inner sense of time: how the brain creates a representation of duration. Nature reviews. Neuroscience. March, 14 (3), p.217-223.

[463] Wittmann, M., Poppel, E. (1999). Temporal mechanisms of the brain as fundamentals of communication with special reference to music perception and performance. Musicae scientiae, September, 3 (1), p.13-28.

[464] Wolpert, R. S. (1990). Recognition of melody, harmonic accompaniment, and instrumentation: Musicians vs. nonmusicians. Music perception, Fall, 8 (1), p.95-106.

[465] Wolpert, D. M., Ghahramani, Z., Jordan, M. I. (1995). An internal model for sensorimotor integration. Science, September, 269 (5232), p.1880-1882.

[466] Wolpert, D. M., Kawato, M. (1998). Multiple paired forward and inverse models for motor control. Neural networks, October, 11 (7-8), p.1317-1329.

[467] Wolpert, D. M., Miall, R. C., Kawato, M. (1998). Internal models in the cerebellum. Trends in cognitive sciences, September, 2 (9), p. 338-347.

[468] Zaidel, M. (1984). Les functions de l'hemisphere droit. (The functions of the right hemisphere.) Recherone, 15 , p. 332-349.

[469] Zaika, E. V., Kuzniecov, M. A. (1989). Kraktovremennaja pamiat' i usvojenie prakticeskih umienij. Voprosy psihologii, 2, p.120-123. [original: Заика, Е. В., Кузнецов, М. А. Кратковременная память и усвоение практических умений. (Short-term memory and the acquisition of practical skill.) Вопросы психологии, 2, с.120-123.]

[470] Zaporozhec, A, V. (1986). Izbrannyje psihologiceskie trudy. 2. Razvitie proizvolnyh dvizhenij. ed. Moscow, Pedagogika, 297 p. [original: Запорожец, А. В. Избранные психологические труды. 2. Развитие произвольных движений. (Selected psychological works. 2. The development of voluntary movements.) изд. Москва, Педагогика, 297 с.]

[471] Zatorre, R. J. Neural specializations for tonal processing. (2001). Annals of the New York Academy of Sciences, June, 930, p.193-210. 
[472] Zatorre, R. J., Belin, P. (2001). Spectral and temporal processing in human auditory cortex. Cerebral cortex, October, 11 (10), p.946-953.

[473] Zatorre, R. J., Belin, P., Penhune, V. B. (2002). Structure and function of auditory cortex: music and speech. Trends in cognitive sciences, January, 6 (1), p.37-46.

[474] Zatorre, R. J., Peretz, I. (2001). The biological foundations of music. Annals of the New York Academy of Sciences, June, 930, $462 \mathrm{p}$.

[475] Zeintl, M., Kliegel, M., Hofer, S. M. (2007). The role of processing resources in age- related prospective and retrospective memory within old age. Psychology and aging, December, 22 (4), p.826-834.

[476] Zohar, D. (1997). ReWiring the corporate brain: Using the new science to rethink how we structure and lead organizations. ed. Berrett-Koehler publishers, $172 \mathrm{p}$.

[477] Zotov, M. V. (2004). Vnimanie, regulacija, affekt: Novye perspektivy issledovanija. In: L. A. Cvetkova, G. M. Jakovleva (eds.), Ananjevskie ctenija. Materialy naucnoj konfernecii 'Sovremennyje problemy kliniceskoj psihologii $i$ psihofizjologii'. 26-28 October. ed. Sankt-Peterburg, SPbGU, 686 p., p.154-163. [original: Зотов, М. В. Внимание, регуляция, аффект: Новые перспективы исследования. (Attention, regulation, affect: New research prospects.) / Л. А. Цветкова, Г. М. Яковлева (ред.), Ананьевские чтения. Материальь научной конференции 'Современные проблемы клинической психологии и психофизиологии'. 26-28 октября. изд. Санкт-Петербург, СПбГУ, 686 с., с.154-163.] 